\title{
Urinary tract infections and antimicrobial agents : a study into factors influencing the efficacy of antimicrobial agents
}

Citation for published version (APA):

Trienekens, T. A. M. (1993). Urinary tract infections and antimicrobial agents : a study into factors influencing the efficacy of antimicrobial agents. [Doctoral Thesis, Maastricht University]. Rijksuniversiteit Limburg. https://doi.org/10.26481/dis.19931222tt

Document status and date:

Published: 01/01/1993

DOI:

10.26481/dis.19931222tt

Document Version:

Publisher's PDF, also known as Version of record

Please check the document version of this publication:

- A submitted manuscript is the version of the article upon submission and before peer-review. There can be important differences between the submitted version and the official published version of record.

People interested in the research are advised to contact the author for the final version of the publication, or visit the DOI to the publisher's website.

- The final author version and the galley proof are versions of the publication after peer review.

- The final published version features the final layout of the paper including the volume, issue and page numbers.

Link to publication

\footnotetext{
General rights rights.

- You may freely distribute the URL identifying the publication in the public portal. please follow below link for the End User Agreement:

www.umlib.nl/taverne-license

Take down policy

If you believe that this document breaches copyright please contact us at:

repository@maastrichtuniversity.nl

providing details and we will investigate your claim.
}

Copyright and moral rights for the publications made accessible in the public portal are retained by the authors and/or other copyright owners and it is a condition of accessing publications that users recognise and abide by the legal requirements associated with these

- Users may download and print one copy of any publication from the public portal for the purpose of private study or research.

- You may not further distribute the material or use it for any profit-making activity or commercial gain

If the publication is distributed under the terms of Article 25fa of the Dutch Copyright Act, indicated by the "Taverne" license above, 


\section{URINARY TRACT INFECTIONS AND ANTIMICROBIAL AGENTS}

A study into factors influencing the efficacy of antimicrobial agents. 


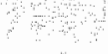

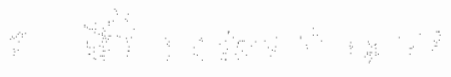

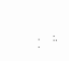

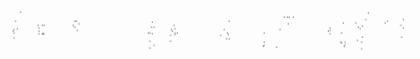

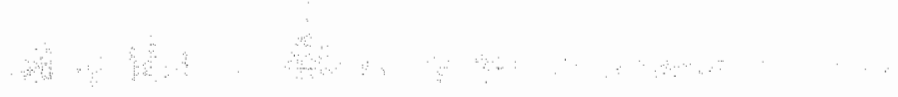




\section{URINARY TRACT INFECTIONS}

AND ANTIMICROBIAL AGENTS

A study into factors influencing the efficacy of antimicrobial agents

\section{PROEFSCHRIFT}

Ter verkrijging van de graad van doctor

aan de Rijksuniversiteit Limburg te Maastricht, op gezag van de Rector Magnificus, prof.dr. H. Philipsen, volgens het besluit van het College van Dekanen, in het openbaar te verdedigen op woensdag, 22 december 1993 om 16.00 uur

door

THEODORA ANTOINETTA MARIA TRIENEKENS

geboren te Tegelen

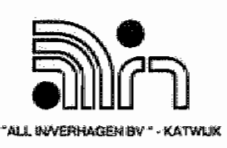


Promotores:

Prof . Dr. C.P.A. van Boven

Prof. Dr. J.A. Knottnerus

Co-promotor:

Dr. E.E. Stobberingh

Beoordelingscommissie: Prof. Dr. J.P.M. Geraedts (voorzitter)

Prof. Dr. D.M. MacLaren (Vrije Universiteit Amsterdam Prof. Dr. P. Pop

Prof. Dr. D. Post (Rijksuniversiteit Groningen)

Prof. Dr. J.W. van Ree 


\section{CONTENTS}

chapter I Introduction

Aims of the study

chapter II Antibiotic susceptibility patterns of uropathogens isolated from general practice patients in the south of the Netherlands. Submitted for publication.

chapter III Different lenghts of treatment with co-trimoxazole for acute uncomplicated urinary tract infections in women. Brit Med J 1989; 299: 1319-1322.

chapter IV Treating acute urinary infections. An RCT of 3-day versus 7-day norfloxacin. Can Fam Phys 1993; 39: 514-518.

chapter V Aerobactin and other virulence associated factors of Escherichia coli and influence of subminimal concentrations of fluoroquinolones. Submitted for publication.

chapter VI Influence of quinolones on the adherence and production of $\mathrm{P}$ fimbriae of Escherichia coli. Submitted for publication.

chapter VII General discussion.

Summary.

Samenvatting.

Dankwoord.

Curriculum vitae. 
In herinnering aan mijn ouders.

Aan Quir. 

De uitgave van dit proefschrift werd mede mogelijk gemaakt door een bijdrage van Merck, Sharp and Dohme, Haarlem. Omslag: The physician examining the urine. B. Johannes de Vetham,
Fasciculus Medicinae, Venice 1493 .

viii 
CHAPTER I

\section{INTRODUCTION}

AIMS OF THE STUDY. 
Chapter I

\section{INTRODUCTION}

One of the most common diseases encountered in general practice are urinary tract infections (UTD ${ }^{1,2}$. This disease accounts for a high morbidity rate in otherwise healthy people. A standardized general practice will have two visits a week from patients with complaints of UTI. Antimicrobial agents will be prescribed to patients with complaints of UTI many times.

The first known description of UTI was presented by ar-Rhazi or Rhazes in the ninth century (AD). He was a physician in Bagdad and described in one of his more than 150 publications a patient undoubtly suffering from pyelonephritis. He also mentioned an effective therapy for this patient. The patient was given diuretics to clean his bladder until the urine became free of pus (leucocytes) and the fever disappeared. In older literature more descriptions of UTI and its therapy were presented, but they did not reach the therapeutic level of the Arabian approach ${ }^{3}{ }^{3}$.

In 1863 Pasteur observed that urine was a good culture medium for bacteria, but it was not until 1881 that Roberts described the relation between the presence of bacteria in urine and complaints of cystitis. In 1894 Escherich isolated from the urine of children with cystitis bacteria which were later named after him: Escherichia coli. This micro-organism is still the most frequent causative agent of UTI in general practice.

A renewed interest into UTI occurred in the thirties of this century ${ }^{4}$. The relations between chronic pyelonephritis and hypertension, premature delivery and end-stage renal failure was investigated. As a result of bacteriuria, arteriosclerotic arteries developed in the kidneys without the presence of overall arteriosclerosis. This renal arteriosclerosis was believed to be the cause of the hypertension and the end- stage renal disease in these patients. In pregnant women with asymptomatic bacteriuria, an increased chance of pyelonephritis existed, because of the altered anatomy, which might lead to premature birth.

Bacteriuria was the key in this and Kass investigated what number of bacteria caused a significant bacteriuria in asymptomatic women ${ }^{5}$. This criterium $\left(\geq 10^{5} \mathrm{cfu} / \mathrm{ml}\right)$ could then be used to search for patients at risk. At that time treatment had improved. In the beginning urinary acidification with mandelic acid was used but the simultaneous discovery of the sulphonamides in about 1935 was more promising. A great search for other and more active antimicrobial agents was undertaken ${ }^{3}$. By now an enormous number of antibacterial agents have been developed and synthesized, some of which have been proved to be of use in UTI in general practice. 


\section{EPIDEMIOLOGY}

UTI is a very common disease. Incidence ranges from $15-65$ per 1000 patients per year depending on the population studied ${ }^{6,7}$. Until the age of one year $0.7-3.5 \%$ boys and $0.3-1.0 \%$ girls experiences a UTI. After the age of one the majority of patients is seen in girls and women. From one to ten years of age $1 \%$ of the boys and $3 \%$ of the girls will experience a period of UTI ${ }^{9}$. The prevalence increases with age to about $10 \%-15 \%$ in women aged 60 years and older. For the Netherlands the following data are available from a study of Lamberts et al. of the department of general practice of the university of Amsterdam in 1989 among 1005 patients complaining of $\mathrm{UTI}^{2}$.

Table IIFFERENCES BETWEEN MEN AND WOMEN AND AGE IN GENERAL PRACTICE ?.

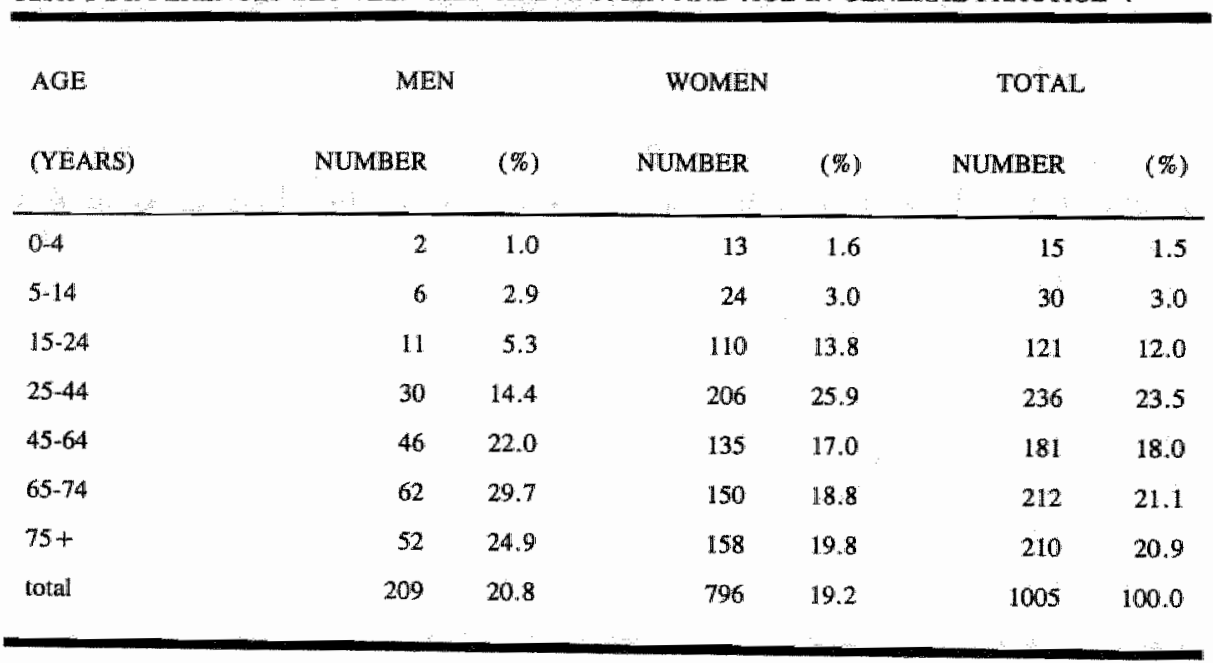

UTI can be divided into asymptomatic bacteriuria (ABU), cystitis (CYS) and pyelonephritis (PYE) ${ }^{11}$. The most prevalent symptoms in CYS and PYE are dysuria, stranguria, frequency and urgency, whereas PYE also shows symptoms of fever $\left(>38^{\circ} \mathrm{C}\right)$, chills and flankpain. All three have in common their significant bacteriuria ${ }^{12}$. With respect to the management of UTI a division can be made between complicated and uncomplicated $\mathrm{UTI}^{13}$. In uncomplicated infections no factors other than the bacterial infection of the urinary tract play a role, while in complicated infections factors such as urinary tract anomalities, stones and urine reflux play a role. 
Infections can also be divided into upper and lower UTI, where upper UTI are located above or ascending from the bladder into the kidneys ${ }^{14}$. All divisions but also combinations of them are used in literature to describe infections of the urinary tract, depending on the situation.

The bacteria causing UTI are usually facultative aerobic Gram negative rods $^{8}$. In uncomplicated infections Escherichia coli is the most frequent causative agent ${ }^{15}$. In more complicated infections other Gram negative bacteria such as Proteus spp, Klebsiella spp and Enterobacter spp together with Pseudomonas spp, enterococci and staphylococci become more and more impor$\operatorname{tant}^{13}$. Chlamydia spp and other fastidious microorganisms might play a role as well in complicated $\mathrm{UTI}^{12}$. Anaerobic pathogens rarely cause urinary tract infections ${ }^{16,17}$.If the UTT is treated cure or failure might occur. A failure means recurrence of the bacteria into the bladder. A relapse is a post-treatment recurrence of the same organism as was originally isolated. Reinfection means recurrence of bacteriuria after treatment due to another organism ${ }^{18}$.

\section{HOST DEFENCES AND PATHOGENESIS}

There are two ways by which bacteria can spread into the urogenital tract; the ascending and descending pathway ${ }^{3}$. In the latter pathway the bacteria originate from an infection elsewhere in the body and infect the urinary tract via the bloodstream. However this rarely occurs in humans. More important is the spread via the ascending route in which bacteria originate from the bowel flora and ascend into the urinary tract.

The first and most important step in the pathogenesis of UTI is bacterial adhesion to the epithelium, followed by colonization and infection ${ }^{19}$.

Before adherence takes place, the microorganisms first have to overcome a number of defence mechanisms of the host. Although urine is considered to be a good culture medium, it does possess antibacterial activity especially for anaerobic and other fastidious organisms of the urethral flora. A high urea concentration and a low $\mathrm{pH}$ are growth inhibiting. The natural flushing mechanism to clear the bladder of bacteria, and the presence of a bladder surface mucopolysaccharide, glycoaminoglycan, seem responsible for a natural resistance to bacterial adherence. Once infection has occurred, other defence mechanisms of the bladder uroepithelium such as mobilization of leucocytes, phagocytosis and bacterial destruction are used to combat the bacteria ${ }^{3}$.

The way in which bacteria colonize the urinary tract has led to two theories.

The first one is the socalled "host-susceptibility theory"; i.e. the colonization of the vaginal introitus and periurethral region by microorganisms 
always preceeds an UTI. Host factors rather than specific pathogenicity of the microorganisms are the important determinants of colonization.

The second is the "chance colonization theory"; i.e. not the host but the bacterial characteristics determine whether or not an infection will take place $e^{20}$. ${ }^{24}$. In this concept the periurethral colonization with a specific microorganism preceeds a significant bacteriuria with the same organism.

However, the organisms must not only bind to the epithelium but also multiply and bind to newer epithelial cells, because older cells attached with bacteria will be swept away by fluid flow. This means that adhesion is an important factor in pathogenicity and a prerequisite for local bacterial proliferation. However, bacteria do not cause disease by adhesion only, other virulence factors are important as well ${ }^{25}$.

\section{VIRULENCE FACTORS}

The research performed with Escherichia coli on the specific virulence factors that enable bacteria to overcome host defences have shown that in addition to fimbriae that mediate adherence, also the presence of the aerobactin system, the production of hemolysin and the presence of certain $\mathrm{O}$ and $\mathrm{K}$ antigens are important virulence factors ${ }^{26-30}$. In table II the association of these virulence factors with different types of UTI are shown as described by John$\operatorname{son}^{31}$.

Table II PREVALENCE OF VIRULENCE FACTORS ${ }^{31}$

\begin{tabular}{lrrr}
\hline & & \\
URINARY TRACT & & & \\
INFECTION & PIRULENCE FACTORS & \\
& & AEROBACTIN & HEMOLYSIN \\
pyelonephritis & 70 & 73 & 49 \\
cystitis & 36 & 49 & 40 \\
$\begin{array}{l}\text { asymptomatic } \\
\text { bacteriuria }\end{array}$ & 24 & 38 & 20 \\
faeces & 19 & 41 & - \\
& & & \\
\hline
\end{tabular}

ADHERENCE AND FIMBRIAE

As already stated, adherence is considered to be the first step in colonization and an essential step prior to infection ${ }^{32}$. It is generally accepted that adhesion is mediated by adhesins called fimbriae. Fimbriae have the property to agglutinate certain erythrocytes, a reaction by which they can be characte- 
rized. They are roughly divided into mannose resistant hemagglutinating (MRHA) and mannose sensitive hemagglutinating (MSHA) fimbriae ${ }^{27}$. Evidence for the importance of fimbrial adhesion was, among others, given by Svanborg-Eden ${ }^{33}$, who demonstrated that fimbriae which mediated MRHA were significantly more prevalent in bacterial strains isolated from patients with symptomatic UTI than in asymptomatic bacteriuria. In addition, it was shown that adherent bacteria cause a decrease in urethral motility and were able to ascend to the kidney ${ }^{34}$.

Morphologically, fimbriae are thin fiberlike appendages with a length of approximate $0.2-20 \mu \mathrm{m}$ and a diameter of $2-7 \mathrm{~nm}$. Chemically fimbriae are protein polymers composed of approximate 1,000 identical subunits per fimbriae. The molecular mass ranges from 15,000 to $30,000^{25}$.

The relevant receptors for most fimbriae are glycoconjugates, which act as lectins using carbohydrates as their receptor sites. The fimbriae can be distinguished on basis of their receptor specificity. $P$ fimbriae are able to bind to the $\alpha-D-G a l-(1-4)-B-D-G a l$ part of glycolipid structures. $P_{1}, P_{2}, P^{k}{ }_{1}$ and $P_{2}^{k}$, but not the $p$ blood group ${ }^{35}$ antigens are oligosaccharides containing a Gal $(\alpha 1$ 4) GalB part. Therefore $P$ blood group erythrocytes can be used for detecting $P$ fimbriae using an HA assay. Other fimbriae bind to $\alpha$-Sialyl-(2-3)- $\beta$-Gal ( $S$ fimbriae) $^{36}$ or a $\mathrm{N}$-acetyl-glucosamine (GlcNac) containing receptor ( $\mathrm{G}$ fimbriae $)^{37}$. Fimbriae, whose specific adhering property is not yet identified, are called X fimbriae. Type I fimbriae are MSHA fimbriae binding to $\alpha$-D-mannose. Also non-HA such as type $1 \mathrm{C}$ fimbriae ${ }^{38}$ and $\mathrm{M}$ fimbriae ${ }^{39}$ exist, along with nonfimbrial or afimbrial adhesins (afa) $)^{40,41}$.

Apart from their binding capacity, fimbriae can be serologically discriminated: type I fimbriae form group F1A, whereas P fimbriae form group F7 to F14 ${ }^{42}$. Monoclonal antibodies against the several serotypes of the $P$ fimbriae used to immunize patients in an attempt to prevent UTI do not crossreact. It appears that anti-P-fimbrial immunity protects against renal infection with homologous $\mathrm{P}$ fimbriae, but not with heterologous $\mathrm{P}$ fimbriated strains. Therefore, it is not very likely that prevention of all UTI with anti-P-fimbrial antibodies will be successful ${ }^{3,43,44}$.

The most important fimbriae in UTI are P fimbriae. The actual genes involved in the production of $\mathrm{P}$ fimbriae are located on the chromosome. The $P$ fimbrial proteins PapA to I are encoded by a gene cluster called Pap ${ }^{45}$. PapA is necessary for the formation of fimbriae and is responsible for the long chain of identical polymerized subunits forming the fimbriae ${ }^{46}$. PapG is the actual adhesin molecule ${ }^{47}$, which is linked to the fimbriae by PapE and F (called minor pilins) ${ }^{48,49}$. PapC forms the assembly platform for fimbrial growth. PapD is a periplasmic protein which forms complexes with the fim- 
brial subunits before assembly. PapH affects the length of the pilin and PapH and I play a role in the regulation of the gene cluster ${ }^{50}$. The physical map of the $P$ fimbrial gene cluster is similar among the various $F$ types ${ }^{51}$.

The distribution of strains expressing $P$ fimbriae is shown in table $I^{11}$. In addition a number of studies suggested that the fecal carriage of $P$ fimbriated strains appears to be higher in patients with pyelonephritis than in normal controls $\mathrm{s}^{35.52}$

\section{AEROBACTIN}

Iron is needed in essential biochemical reactions and in oxygen transport $^{53}$. Therefore organisms have developed efficient mechanisms for the acquisition, storage and transport of iron ${ }^{54}$. In most uropathogenic Escherichia coli strains the siderophore aerobactin is present. Aerobactin competes with transferrin and lactoferrin for bound iron and transports the iron ${ }^{28}$.

Aerobactin is a hydroxamate derivative of two lysine molecules coupled to one citric acid and after binding, transports the iron to the bacterial membrane receptor protein $(74 \mathrm{kDa})$. The aerobactin system is encoded by a five gene operon. Four genes are encoding for the aerobactin synthesis termed iuc (iron uptake chelate), the fifth encodes the outer membrane receptor protein and is termed iut (iron uptake transport). In short, the aerobactin production is as follows: lysine is oxydized by an oxygenase (product of iudD), then catalyzed by the product of iucB. The synthetase (products of iucA and iucC) occurs in the next step (two discrete steps). Gene iutA encodes the outer membrane receptor ${ }^{55.56 .57}$.

Aerobactin production is commonly detected using a bioassay ${ }^{58}$. A bioassay to determine the sensitivity to cloacin can also be used, because the same receptor is responsible for both aerobactin and cloacin uptake. Nowadays DNA hybridization assays are performed. A probe either encoding the biosynthesis genes or for the receptor is used. The bioassay and the probes give the same results ${ }^{59}$.

Aerobactin was identified as a virulence factor in pioneering studies. These investigators used isogenic strains, which only differ in their ability to produce aerobactin and they clearly demonstrated the contribution of aerobactin to the virulence of the bacteria ${ }^{60,61,62}$.

\section{HEMOLYSIN PRODUCTION}

Escherichia coli strains commonly secrete the protein $\alpha$-hemolysin, which is active against erythrocytes of various animals and humans ${ }^{63}$. In addition to lysing erythrocytes, hemolysin is cytotoxic to a variety of cells such as polymorphonuclear neutrophiles (PMNs), monocytes and granulocytes, whereas lymfocytes are relatively resistant. 
Hemolysin production is encoded by a four-gene operon termed hly $A$ $D$, which is located on the chromosome of Escherichia coli strains $^{64}$. HlyA encodes for the structural hemolysin protein. To bind the erythrocytes HlyA must be activated by HlyC prior to its secretion. The first step in hemolysin secretion is an energy dependent process involving HlyB, whereas release from the outer membrane is passive and requires HlyD.

The distribution of bacteria from different types of UTI expressing hemolysin production is shown in table II. Although most hemolytic uropathogens are closely associated with P fimbriae a number of studies clearly demonstrated the importance of hemolysin production as a virulence factor.

$O$ AND K ANTIGENS.

In the same way the association between virulence factor and UTI the pathogenicity for certain $\mathrm{O}$ and $\mathrm{K}$ serotypes was documented. Only a limited number of $\mathrm{O}$ and $\mathrm{K}$ serotypes were associated with UTI e.g. $\mathrm{O} 1, \mathrm{O} 2, \mathrm{O} 4,06$, $\mathrm{O} 7, \mathrm{O} 18$ and $\mathrm{O} 75$ and $\mathrm{K} 1, \mathrm{~K} 2, \mathrm{~K} 3, \mathrm{~K} 12, \mathrm{~K} 13^{65-70}$. However, the relation between serologic typing and other virulence factors has not been ellucidated and also the role of $\mathrm{O}$ and $\mathrm{K}$ antigens in pathogenicity is not yet clear.

\section{TREATMENT OF UTI}

\section{EFFICACY AND RESISTANCE}

A considerable amount of antimicrobial agents is used in general practice for the empirical treatment of UTI. Treatment of UTI in a symptomatic patient is generally started before the result of the urine culture is known, on the basis of history, physical examination and microscopic examination of the urine sediment ${ }^{3}$ with a general accepted duration of 7 to 10 days.

Efficacy of antimicrobial therapy depends among others on the most likely causative microorganism and its susceptibility to the antimicrobial agent used. It is also obvious that a recent knowledge of the percentages of resistant bacteria causing acute cystitis in general practice will be of help to the general practitioner to prescribe an adequate therapy. He should have knowledge of the frequencies of susceptibility, because differences between regions, type of infections and patients have been described. In this regard the most important factor, in addition to safety, tolerance, risk of bacterial resistance, costs and way of administration are the susceptibilities of Escherichia coli. Recent data of these susceptibility rates for the mostly used antimicrobial agents are described below.

Sulphonamides have been widely used in the treatment of UTI. They are still recommended by the Dutch General Practitioners Association (NHG) ${ }^{71}$ as one of the three first-choice agents, together with trimethoprim and nitrofuran- 
toin. However, $22 \%$ of Escherichia coli isolated in general practice in the south of the Netherlands are resistant to sulphonamides ${ }^{72}$. Even higher percentages were found in other parts in the Netherlands and in other countries ${ }^{73}$. 74,75. Although sulphonamides are attractive antimicrobial agents for treatment with respect to costs, the relative high frequency of resistance decreases its efficacy.

Trimethoprim is a recommended antimicrobial agent for UTI in the Netherlands. Resistance occurs in about $10 \%$ of Escherichia coli ${ }^{76}$. However, in Escherichia coli strains isolated in Finland a resistance percentage of $40 \%$ is observed ${ }^{77,78}$ and therefore it is not recommended for treatment of UTI in this country. In countries where the susceptibility is still high, it is still suitable.

The combination of sulphamethoxazole and trimethoprim is effective against the majority of common urinary pathogens. The resistance percentage recorded was found to be $10-20 \%$ in Escherichia coli $^{74,76.79}$. The effect of the combination is probably due to the combination. Therefore trimethoprim alone should be preferred in stead of the combination ${ }^{4}$.

Amoxicillin has been widely used in the treatment of UTI. Several studies have shown that $30 \%$ to $40 \%$ of Escherichia coli in general practice are resistant in the Netherlands $s^{73,76}$. Since the resistance is caused by a $B$-lactamase it is apparent that the combination of amoxicillin and a B-lactamase inhibitor, clavulanic acid, is active against almost all general practice isolates $^{73,76}$.

Another effective agent in the treatment of general practice derived UTI is nitrofurantoin. Although its efficacy is slightly limited by the intrinsic resistance of Proteus spp, it is still a suitable agent, because in general practice Escherichia coli is the most frequent cause of uncomplicated UTI in female patients. Therefore this agent is still recommended to Dutch general practitioners as a first choice agent for acute cystitis treatment ${ }^{71}$.

Recently a new group of antimicrobial agents, the fluoroquinolones became available for treatment of infections. Two components, norfloxacin and ciprofloxacin, are very attractive for treating UTI and they have a wide spectrum of activity. In addition to the usually causative pathogens they are in general active against less frequently isolated pathogens in GP such as Pseudomonas aeruginosa and group D streptococci $1^{80,81}$. Although they have a very low frequency of resistance, development of resistance to these agents can be expected and has been described. Therefore it is questionable whether these agents must be used in general practice. 


\section{THREE DAYS TREATMENT}

As mentioned before, the generally accepted course for UTI is 7 to 10 days. A number of considerations including the high spontaneous cure rate, the limited compliance of patients to treatment and the observation that bacteria are eradicated from the urine within 24 to 48 hours with adequate antimicrobial agents have raised the question if a 7 to 10 days' course is optimal. In addition the exposure of bowel flora to antimicrobial agents became an increasing concern, because the feacal reservoir is believed to be the place were resistance development occurs. The shorter the treatment duration the lesser the chance of resistance.

Both these areas of concern have led to a large number of studies into efficacy of short term treatment courses ${ }^{82-91}$. Reviewing recent studies on a single-dose and a short course treatment of antimicrobial agents for acute uncomplicated UTI in non-pregnant female patients, the most striking fact was that although for a long period of time short-term treatment had received a lot of attention, no well designed and performed randomized clinical trials were available. As pointed out by Fihn and Stamm $^{92}$, and also by Philbrick ${ }^{93}$ in their reviews on single dose treatments for uncomplicated UTI, the majority of studies do not fulfill the basic principles of randomized controlled trial design. One of the major objections is that the number of patients is too low to draw valid conclusions (a type II error).

Recentlly Norrby ${ }^{94}$ evaluated 28 published trials, which fullfilled the minimum criteria of randomized controlled trials. He concluded that a three days ${ }^{\prime}$ course of antimicrobial agents was the most optimal treatment duration. The results of these studies evaluated by Norrby, although many trials were not double-blinded, have resulted in a change with respect to the treatment of UTI. A short course is now generally advocated as an acceptable appraoch. This is also indicated by recent recommendations of the NHG, the National Organization for Quality Insurance in Hospital (CBO) and the Drug Bulletin (Geneesmiddelenbulletin) $^{95,96}$. However, as Norrby pointed out, it must be kept in mind, that the results cannot be extrapolated to other antimicrobial agents, therefore adequate and additional studies are necessary.

\section{SUBINHIBITORY CONCENTRATIONS}

From the earliest days on, numerous reports were published on the effects of subinhibitory concentrations of antimicrobial agents on bacteria ${ }^{97-103}$. Gram negative bacteria, elongated and filamentous, and Gram positive bacteria enlarged with incomplete fission were observed in the presence of subinhibitory concentration of antimicrobial agents.

The effect of subinhibitory concentrations of antimicrobial agents on bacteria is of interest, in that the disturbance of bacterial metabolism, although 
not always resulting in growth inhibition might influence production and expression of virulence factors ${ }^{104}$. With respect to the pathogenicity of uropathogenic Escherichia coli subinhibitory concentrations of antimicrobial agents might influence the capacity for adhesion and possibly the production of hemolysin and aerobactin production. In clinical practice this might be of importance to explain the efficacy of low dose treatment for the prevention of UTI ${ }^{105,106}$. In his study on subinhibitory concentrations Chopra ${ }^{107}$ explained the effect on bacteria in four different ways; alteration of the overall shape of the bacteria, promotion of the release of adhesins from the bacterial cell surface, promotion of the formation of functionally deficient adhesins (fimbriae) or suppression of the synthesis or secretion of surface located adhesins.

Zhane $1^{108}$ reviewed more specifically nine reports on the effects of subinhibitory concentrations on bacterial adherence of Escherichia coli to uroepithelial cells. The Escherichia coli strains in these studies were chosen either because of their known and well characterized fimbriae or because of their adhering capacity. Except for two studies ${ }^{108,109}$ most of the investigators isolated uroepithelial cells from the sediment of fresh urine from healthy women. A variety of antibiotics in subinhibitory concentrations were tested. The results of the study are summarized in table III;

In general and as pointed out by Zhanel it is obvious that a decreased adherence is observed, although many factors apparently do influence the results. Zhanel suggested that the elongated bacteria, because of clumsy movement, had a lower chance of finding epithelial cells. All nine studies were performed with well adhering bacteria. However, these might not be representative for the usually causative microorganisms. But also within this group of well adhering bacteria with respect to adherence to bladder uroepithelial cells considerable strain to strain variation with the same antibiotic was observed. This might be due to differences in types and amounts of fimbriae, and the receptor sites of the epithelial cells.

With regard to the effects of subinhibitory concentrations of antimicrobial agents on hemolysin production the scant data available do not yet allow conclusions ${ }^{110}$.

The studies on the influence of subinhibitory concentrations of antibiotics on siderophore production indicate that siderophore production is inhibited

The results of the studies reviewed above suggest effects of subinhibitory concentrations of antimicrobial agents on expression and production of virulence factors. It is apparent that the effect of adherence to uroepithelial cells is influenced by antimicrobial agents. It is difficult to predict and it cannot always be explained how interactions between bacteria and antimicrobial 
agents might lead to decreased or increased expression of virulence factors of the antibiotic exposed bacteria.

Table III EFFECT OF SUBMICS OF SEVERAL ANTIMICROBIAL AGENTS

\begin{tabular}{lll}
\hline ANTIBIOTICS & MIC & EFFECT \\
penicillin & $1 / 2,1 / 4$ & $\downarrow$ \\
mitrofurantoine & $1 / 2$ & 1 \\
chloramfenicol & $1 / 4$ & 1 \\
tetracycline & $1 / 2,1 / 4$ & $\downarrow$ \\
& $1 / 8,1 / 32$ & $\uparrow$ \\
doxycycline & $1 / 2,1 / 4$ & $\leftrightarrow$ \\
sulfonamides & $1 / 2$ to $1 / 32$ & $\downarrow$ \\
trimethoprim & $1 / 2$ to $1 / 32$ & $\downarrow$ \\
aminoglycosides & $1 / 2$ & $\downarrow$ \\
quinolones & $1 / 4,1 / 8,1 / 16$ & $\downarrow$ \\
& & $\downarrow$ \\
t: both effects observed & & \\
$\leftrightarrow:$ no effects observed & & \\
$\downarrow$ : diminished effect & & \\
t: increased effect & &
\end{tabular}

\section{AIMS OF THE STUDY}

With respect to the literature as discussed in this chapter several questions are still unanswered. The present study is designed to answer the following problems;

I the prevalence of resistance to antimicrobial agents of bacteria isolated from patients with uncomplicated urinary tract infections from general practice.

II The determination of the optimal duration of antimicrobial treatment for urinary tract infection.

III The effect of subinhibitory concentrations of antimicrobial agents on virulence factors; fimbriae, aerobactin and hemolysin production. 


\section{OUTLINE OF THE THESIS.}

In chapter I a review of the literature is given. Factors influencing t] efficacy of antimicrobial therapy, with an emphasis on bacterial resistanc short term treatment regimens and the effect of subinhibitory concentrations । antimicrobial agents are reviewed.

Chapter II, entitled 'antibiotic susceptibility patterns of uropathogel isolated from general practice patients from the south of the Netherlands describes the antibiotic susceptibilities from uropathogens $(n=1300)$ isolate from patients from general practice and the mechanism of resistance to amc xicillin and to trimethoprim are analyzed. The mechanism of resistance $t$ amoxicillin is investigated by $B$-lactamase detection and characterization. $T h$ mechanism of high level trimethoprim resistance is characterized with probe specifying type $I$ and type $V$ mediated resistance.

In chapter III and IV the results of a double-blind randomized trial ar described, in which a three' days course of an antimicrobial agent is compare with a seven days' course in patients with acute uncomplicated cystitis presen ting to the general practitioner. Special attention has been paid to the numbe of patients needed to draw valid conclusions. Chapter III studies co-trimoxa zole and the paper is entitled: Different lenghts of treatment with co-trimoxa zole for acute uncomplicated urinary tract infections in women. Chapter IV studies norfloxacin and is entitled: A double-blind randomized study of threx days versus seven days norfloxacin for acute uncomplicated urinary trac infections in general practice.

In chapter $V$ entitled 'influence of fluoroquinolones on aerobactin anc virulence associated factors of Escherichia coli', the presence of aerobactin, hemolysin, hemagglutination and $\mathrm{O}$ and $\mathrm{K}$ antigens in two groups of uropathogens is described. The first group included strains isolated from female patients seeing their general practitioner with complaints of an uncomplicated UTI, the second group comprised Escherichia coli isolated of the urine of pregnant women with an asymptomatic bacteriuria. A control group consisted of bacteria isolated from patients with an urosepsis. The influence of quinolones (norfloxacin, ofloxacin and ciprofloxacin) on the hemolysin production was investigated for all strains. The influence of subinhibitory concentrations of antimicrobial agents on the aerobactin encoded RNA was investigated with a specific DNA probe in six randomly chosen strains.

Chapter VI, entitled "influence of quinolones on the adherence and production of P fimbriae of Escherichia coli", presents the results of the study of the influence of quinolones on the adherence to uroepithelial cells and especially on $\mathrm{P}$ fimbriae. The same bacteria as described in chapter $\mathrm{V}$ were 
used. The influence of subinhibitory concentrations of ciprofloxacin, ofloxacin and norfloxacin on bacteria to the adherence of a T24 uroma celline was investigated. The obvious influence of subinhibitory concentrations of norfloxacin on the bacteria was further investigated. The $P$ fimbriated bacteria were investigated with a specific DNA probe against $P$ fimbrial RNA and with monoclonal antibodies against the fimbriae.

Chapter VII is the summary and general discussion. In this chapter the results of the studies presented are summarized and discussed. 


\section{REFERENCES}

1 Andriole V.T. Urinary tract infections: recent developments. I Infect Dis 1987; 156: 865-868.

2 Lamberts H. et al. Transition Project. Amsterdam : Department of General Practice of the University of Amsterdam, 1989.

3 Asscher A.W. The challenge of urinary tract infections. 1980. Academic Press.

4 Kunin C.M. Detection, prevention and management of urinary tract infections. fourth edition 1987. Lea \& Febiger Philadephia. Inc. London.

5 Kass E.H. Asymptomatic infections of the urinary tract. Trans Assoc Am Phys 1956; 69: 56-63.

6 Baselier P.J.A.M. Acute bacteriële urineweginfecties in de huisartspraktijk. Thesis Nijmegen 1983. Krips Repro Meppel.

7 Valkenburg H.A. Epidemiology of urinary tract infections. Eur Urol 1987; suppl 1: 5-8.

8 Iravani A. Urinary tract infections: epidemiology and therapeutic approaches. In; The management of urinary tract, genitourinary and skin and soft infections with cefuroxime-axetil. R.G. Finch (ed) 1988, no 127: Royal Society of Medicine Services Limited.

9 Winberg J., HJ.Andersen, T.Bergström, B.Jacobson, H.Larson, K.Lincoln. Epidemiology of symptomatic urinary tract infection in childhood. Acta Paediatr Scand 1974; Suppl 252:1-20.

10 Hooton T.M. Epidemiology, definitions and terminology in urinary tract infections p 1-8 In; H.C.Neu, J.D.Williams (ed) New trends in urinary tract infections. (International Symposium on new trends in urinary tract infections, Rome, January 30-31,1987.) 1988 Karger AG, Basel.

11 Ronald A.R., B. Conway. An appraoch to urinary tract infections in ambulatory women. Current topics in infectious diseases. 1986 p 76124. Eds. Remington and Schwartz.

12 Komaroff A.L. Acute dysuria in women. N Engl I Med 1984;310: 368-375.

13 Preheim L.C. Complicated urinary tract infections. Am J Med 1985; 79 suppl 2A: 62-66.

14 Barza M. Urinary tract infections in Schaechter M., G.Medoff, D. Schlesinger. Mechanisms of microbial disease. Williams and Wilkins 1989; Chapter 48: 669-682. 
15 Johnson J.R., W.E.Stamm. Urinary tract infection in women; diagnosis and treatment. Ann of Int Med 1989; 111: 906-917.

16 Fairley K.F., D.F.Birch. Detection of bladder bacteruria in patients with acute urinary symptoms. J Infect Dis $1989 ; 159: 226-231$.

17 Maskell R. A new look at the diagnosis of infection of the urinary tract and its adjacent structures. J Infect 1989; 19: 207-217.

18 Medical Research Council Bacteriuria Committee Recommened terminology of urinary tract infection. Brit Med J 1979: 2: 717-719.

19 Beachey E.H. Bacterial adherence: adhesin-receptor interactions mediating the attachment of bacteria to mucosal surfaces. J Infect Dis1981; 143: 325-345.

20 Fowler J.E., R.Latta, T.A.Stamey. Studies of introital colonization in women with recurrent urinary infections. VII. The role of bacterial interference. J Urol 1977; 118: 296-298.

21 Schaeffer A.J., J.M.Jones, J.K.Dunn. Association of in vitro Escherichia coli adherence to vaginal and buccal epithelial cells with susceptibility of women to recurrent urinary tract infections. $N$ Engl $J$ Med 1982; 304: 1062-1066.

22 Cattell W.R., M.A. McSherry, A.Northeast et al. Periurethral enterobacterial carriage in pathogenesis of recurrent urinary infection. $\mathrm{Br}$ Med J 1974; 4: 136-139.

23 Kunin C.M., F.Polyak, R.Postel. Periurethral bacterial flora in women. Prolonged intermittent colonization with Escherichia coli. JAMA 1980; 243: 136-139.

24 Kunin C.M., C.Steele. Culture of the surfaces of urinary catheters to sample urethral flora and study the effect of antimicrobial therapy. I Clin Microbiol 1985; 21: 902-908.

25 Krogfelt K.A. Bacterial adhesion: Genetics, biogenesis, and role in pathogenesis of fimbrial adhesins of Escherichia coli Rev Infect Dis 1991; 13: $721-735$.

26 Harber M.J. Virulence factors of urinary pathogens. Clin Sci 1986; 70: 531-535.

27 Duguid J.P., S.Clegg, M.I.Wilson. The fimbrial and non-fimbrial haemagglutinins of Escherichia coli. J Med Microbiol ,1979; 12: 213227.

28 Neilands J.B. Mechanism and regulation of synthesis of aerobactin in Escherichia coli K12 (pColV-K30). Can J Microbiol 1992; 38: 728-733.

29 Bosch van den J.F., P.Postma, J.dGraaf, D.M.MacLaren. Determination of the $\alpha$-haemolytic activity of haemolytic urinary Escherichia coli strains. FEMS Microbiol Lett 1980; 8: 75-77. 
30 Orskov I., F.Orskov. Serologic classification of fimbriae. In K.Jann and B.Jann (eds) Bacterial adhesins, Current topics in microbiology and. immunology, volume 151, 1990. Springer Verlag, Berlin.

31 Johnson J.R. Virulence factors in Escherichia coli urinary tract infections. Clin Microbiol Rev 1991; 4: 81-128.

32 Virkola R., B.Westerlund, H.Holthöfer, J.Parkkinen, M.Kekomäki, T.K.Korhonen. Binding characteristics of Escherichia coli adhesins in human urinary bladder. Infect \& Immun 1988; 56: 2615-2622.

33 Svamborg-Eden C., U.Jodal, L.Å.Hanson, U.Lindberg, A.SohlÅkerlund. Variable adherence to normal human urinary tract epithelial cells of Escherichia coli strains associated with various forms of urinary tract infection. The Lancet 1976, 490-492.

34 Shapiro E.D. Infections of the urinary tract. Paediatr Infect Dis J 1992; 11: $165-168$.

35 Kållenius G., S.B.Svensson, H.Hultberg, J.Winberg, R. Möllby, I.Helin, B.Cedergren. Occurrence of $\mathrm{P}$ fimbriated Escherichia coli in urinary tract infections. Lancet 1981; 1369-1372.

36 Hacker J. Genetic determinants coding for fimbriae and adhesins of extraintestinal Escherichia coli. Curr Top Microbiol Immun 1990; 151: $1-27$

37 Rhen M., P.Klemm, T.K.Korhonen. Identification of two new hemagglutinins of Escherichia coli, N-acetyl-D-glucosamine specific fimbriae and a blood group $M$ specific agglutinin, by cloning the corresponding genes in Escherichia coli $\mathrm{K}-12$. J Bacteriol 1986; 168: 12341242.

38 Die v I., B.v.Geffen, W.Hoekstra, H.Bergmans. Type IC fimbriae of a uropathogenic Escherichia coli strain: cloning and characterization of the genes involved in the expression of the $1 \mathrm{C}$ antigen and nucleotide sequence of the subunit gene. Gene 1984; 34: 187-196.

39 Väisänen V., T.K.Korhonen, M.Jokinen, C.G.Gahmberg,C. Ehnholm. Blood group $\mathbf{M}$ specific haemagglutination in pyelonephritogenic Escherichia coli. Lancet 1982; ii: 1192.

40 Hales, B.A., H.Beverley-Clarke, N.J.High, K,Jann, R.Perry, J. Goldhar, G.J.Boulnois. Molecular cloning and characterization of the genes for a non-fimbrial adhesin from Escherichia coli Microb Pathog 1988; 5: 9-17.

41 Eshdat Y., I.Ofek, Y.Yashouv-Gan, N.Sharon, D.Mirelman. Isolation of a mannose-specific lectin from Escherichia coli and its role in 
the adherence of the bacteria to epithelial cells. Biochem Biophys Res Commun 1978; 85: 1551-1559.

42 Orskov I. and F.Orskov. Serology of Escherichia coli fimbriae. In L.A.Hanson, P.Kallós, O. Westphal (eds). Host-parasite relationships in gram negative infections. Prog.Allergy 1983; 33: 80-105.

43 Pecha B., D.Low, P.O'Hanley Gal-Gal pili vaccines prevent pyelonephritis by piliated Escherichia coli in a murine model. J Clin Invest 1989; 83: 2102-2108.

44 Silverblatt F.J., R.Weinstein, P.Rene. Protection aginst experimental pyelonephritis by antibodies to pili. Scand J Infect Dis 1982; Suppl 33: $79-82$.

45 Lund B., F.Lindberg, B-I. Marklund, S.Normark. The PapG protein is the $\alpha$-D-Galactopyranosyl-(1-4)-B-D-galactopyranose-binding adhesin of uropathogenic Escherichia cali. Proc Natl Acad Sci 1987; 84: 58985902.

46 Båga M., S.Normark, J.Hardy, P.O'Hanley, D.Lark, O.Olsson, G.Schoolnik, S.Falkow. Nucleotide sequence of the papA gene encoding the pap Pilus subunit of human uropathogenic Escherichia coli. J Bacteriol 1984; 157: 330-333.

47 Lindberg F., B.Lund, L.Johansson, S.Normark. Localization of the receptor-binding protein adhesin at the tip of the bacterial pilus. Nature 1987; 328: 84-87.

48 Hultgren S.J., F.Lindberg, G.Magnusson, J.Kihlberg, J.M. Tennent, S.Normark. The papG adhesin of uropathogenic Escherichia coli contains separate regions for receptor binding and for the incorporation into the pilus. Proc Natl Acad Sci USA 1989; 86: 4357-4361.

49 Lindberg F., B.Lund, S.Normark. Gene products specifying adhesion of uropathogenic Escherichia coli are minor components of pili. Proc Natl Acad Sci USA 1986; 83: 1891-1895.

50 Båga M., M.Norgren, S.Normark. Biogenesis of Escherichia coli pap pili: $\mathrm{PapH}$, a minor pilin subunit involved in cell anchoring and lenght modulation. Cell 1987; 49: 241-251.

51 Die v.I., I.v.Megen, E.Zuidweg, W.Hoekstra, H.d.Ree, H.v.d.Bosch, H.Bergmans. Functional relationship among the gene clusters encoding $F 7_{1}, F 7_{2}, F 9$ and $F 11$ fimbriae of human uropathogenic Escherichia coli. I Bacteriol 1986; 167: 407-410.

52 Våisånen-Rhen V., L.Elo, E.Våisånen, A.Siitonen, I.Orskov, F.Orskov, S.B.Svenson, P.H.Måkela, T.K.Korhonen. P-fimbriated clones among uropathogenic Escherichia coli strains. Infect \& Immunol 1984; 43: $149-155$. 
53 Griffiths E. Candidate virulence markers in Sussman M. (ed) The virulence of Escherichia coli 1985. Academic Press, London.

54 Herschko C., T.E.A.Peto, D.J.Weatherall. Iron and infection. Brit Med J 1988; 296: 660-664.

55 J.B.Neilands. Parallels in the mode of regulation of iron assimilation in all living species. Chapter 3 in RemPonka (eds). Iron transport and storage 1990. CRC Press inc Florida.

56 Carbonetti N.H., P.H.Williams. A cluster of five genes specifying the aerobactin iron uptake system of plasmid colV-K30. Infect \& Immun. 1984; 46: 7-12.

57 Waters L.V., J.H.Crosa. Colicin V virulence plasmids. Microbiol Rev 1991; 55: 437-450.

58 Orskov I., C.Svanborg-Eden, F.Orskov. Aerobactin production of serotyped Escherichia coll from urinary tract infections. Med Microbiol Immunol 1988; 177: 9-14.

59 Macario A.J.L., E.Conway de Macario (eds). Gene Probes for Bacteria 1990. Academic Press, New York.

60 Williams P.H. Novel iron uptake system specified by ColVplasmids; an important component in the virulence of invasive strains of Escherichia coli. Infect \& Immun 1979; 26: 925-932.

61 Williams P.H., P.J.Warner. ColV plasmid-mediated colicin D-independent iron uptake system of invasive strains of Escherichia coli. Infect \& Immun 1980; 29: 411-416.

62 Lorenzo de D., J.L.Martinez. Aerobactin as a virulence factor: a reevaluation. Eur J Clin Microbiol Infect Dis. 1988;7:621-629.

63 Smith H.W. The haemolysins of Escherichia coli. J Path Bact 1963; 85: 197-211.

64 Welch R.A., R.Hull, S. Falkow. Molecular cloning and physical characterization of a chromosomal hemolysin from Escherichia coli. Infect \& Immun 1983; 42: 178-186.

65 Sitonen A. Escherichia coli in fecal flora of healthy adults; serotypes, $P$ and type $1 \mathrm{C}$ fimbriae, non-P mannose resistant adhesins and hemolytic activity. J Infect Dis 1992;166:1058-1065.

66 Benton J., J.Chawla, S.Parry, D.Stickler. Virulence factors in Escherichia coli from urinary tract infections in patients with spinal injuries. $J$ Hosp Infect 1992; 22: 117-127.

67 Blum G., M.Ott, A.Cross, J.Hacher. Virulence determinants of $E$ scherichia coli 06 extraintestinal isolates analyzed by southern hybridizations and DNA long range mappion techniques. Microbial Path $1991 ; 10: 127-136$. 
68 Green C.P., V.L.Thomas. Hemagglutination of human type O erythrocytes, hemolysin production and serogrouping of Escherichia coli isolates from patients with acute pyelonephritis, cystitis, and asymptomatic bacteriuria. Infect \& Immun 1981; 31: 309-315.

69 Sandberg T., B.Kayser, G.Lidin-Janson, K.Lincoln, F.Orskov, I.Orskov, E.Stokland, C.Svanborg-Eden. Virulence of Escherichia coli J Clin Microbiol 1988; 26: 1471-1476.

70 Stenqvist K., T.Sandberg, G.Lidin-Janson, F.Orskov, I.Orskov, C. Svanborg-Eden. Virulence factors of Escherichia coli in urinary isolates from pregnant women. J Infect Dis. 1987; 156: 870-877.

71 Balen F.A.M. v., P.J.A.M.Baselier, E.vPienbroek, R.A.G.Winkens. Standaard Urineweginfecties Nederlands Huisartsen Genootschap. Huisarts en Wetenschap 1989; 32: 527-530.

72 Trienekens T.A.M., E.E.Stobberingh, R.A.G.Winkens, A.W. Houben. Different lengths of treatment with co-trimoxazole for acute uncomplicated urinary tract infections in women. Brit Med J 1989; 299: 1319-1322.

73 Neeling de A.J., J.de Jong, B.P.Overbeek, R.W. de Bruin, M.Dessens-Kroon, B van Klingeren. Kwantitatief gevoeligheidsonderzoek met intra- en extramurale isolaten van Escherichia coli Rapport nr. 359001002. National Institute of Public Health and Environmental Protection.

74 Abbas A.M.A., B.Ahattopadhyay, C.Dulake. A multicenter antibiotic sensitivity survey of general practice and hospital strains. Proceedings of the 1st symposium on Augmentin: clavulanate potentiated amoxicillin 1980: 173-183.

75 Beale A.S., R.Sutherland. Antibiotic sensitivity of urinary isolates from general practice in Great-Britain in 1984- a multicentre study. Proceedings of 6th Mediterranean Congress of Chemotherapy 1988.

76 Stobberingh E.E., A.W.Houben: Antibioticagebruik en antibioticaresistentie in de huisartspraktijk. N T v G 1990; 132: 1793-1797.

77 Heikkilä E., L.Sündström, P.Huovinen. Trimethoprim resistance in Escherichia coli isolates from a geriatric unit. Antimicrob Agents Chemother 1990; 34: 2013-2015.

78 Steen R., O.Sköld. Plasmid-borne or chromosomally mediated resistance by $\operatorname{Tn} 7$ is the most common response to ubiquitous use of trimethoprim. Antimicrob Agents Chemother 1985; 27: 933-937.

79 Gruneberg R.N. Changes in the antibiotic sensitivities of urinary pathogens, 1971-1989. J Antimicrob Chemother 1990; 26:Suppl F 3-11. 
Hooper D.C., J.S.Wolfson, E.Y.Ng, M.N.Swartz. Mechanism of action and resistance to ciprofloxacin. Am J of Med 1987; 82 suppl 4A: $12-20$.

81 J.S.Wolfson, D.C.Hooper. Norfloxacin: a new targeted fluoroquinolone antimicrobial agent. Ann Int Med 1988; 108: 238-251.

82 Bailey R.R. Review of published studies on single dose therapy of urinary tract infection. Infection 1990; 18: 53-56.

83 Fihn S.D., G. Johnson, P.L. Roberts, K. Running, W.E. Stamm. Trimethoprim-sulfamethoxazole for acute dysuria in women: a single dose or a 10 day course. Annals of Intern Med 1988; 108: 350-357.

84 Gleckman R.A. Treatment duration for urinary tract infections in adults. Antimicr Agents Chemother 1987; 31: 1-5.

85 Rylander M., S.R. Norrby, R. Svard. Norfloxacin versus co-trimoxazole for treatment of urinary tract infections in adults: microbiological results of a coordinated study. Scand J Infect Dis 1987; 19: 551-557.

86 Nicolle L.E. The optimal management of lower urinary tract infections. Infection 1990; 18: 50-52.

87 Reeves D.S., R.W. Lacey, R.V. Mummery, M. Mahendra, A.J. Bint, S.W.B. Newson. Treatment of acute urinary infection by norfloxacin or nalidixic acid/citrate: a multicentre comparative stady. J Antimicrob Chemother 1984; 13: 99-105.

88 Goldstein E.J.C., M.L. Albert, B.P. Ginsberg. Norfloxacin vs. trimethoprim-sulfamethoxazole in the therapy of uncomplicated, community-acquired urinary tract infections. Antimicrob Agents Chemother 1985; 27: 422-423.

89 Sabbaj J., V.L. Hoagland, W.J. Shih. Multiclinic comparative study of norfloxacin and trimethoprim-sulfamethoxazole for urinary tract infections. Antimicr Agents Chemother 1985; 27: 297-301.

90 Urinary Tract Infection Study Group. Coordinated multicenter study of norfloxacin versus trimethoprim-sulfamethoxazole treatment of symptomatic urinary tract infections. J Infect Dis $1987 ; 155: 170-177$.

91 The Internordic Urinary Tract Infection Study Group. Double-blind comparison of 3-day versus 7-day treatment with norfloxacin in symptomatic urinary tract infections. Scand J Infect Dis 1988; 20: 619-624.

92 Fihn S.D., W.E.Stamm. Interpretation and comparison of treatment studies for uncomplicated urinary tract infections in women. Rev Infect Dis $1985 ; 7: 468-478$.

93 Philbrick J.T., J.P.Bracikovski. Single-dose antibiotic treatment for uncomplicated urinary tract infections. Less for less? Arch Intern Med 1985; 145: 1672-1678. 
94 Norrby S.R. Short-term treatment of uncomplicated lower urinary tract infections in women. Rev Infect Dis. 1990; 12: 458-467.

95 Wetenschappelijke Raad Centraal Begeleidingsorgaan voor de Intercollegiale Toetsing. Het syndroom van de acute pijnlijke frequente mictie en de patient met een langdurige verblijfscatheter. juni 1988.

96 Mattie H., P.J.vd Broek. De behandeling van ongecompliceerde urineweginfecties: lang, kort of met één dosis behandelen. Geneesmiddelenbulletin 1991; 25: 46-48.

97 Schifferli D.M., E.H.Beachey. Bacterial adhesion: modulation by antibiotics with primary targets other than protein synthesis. Antimicr Agents Chemother 1988; 32: 1609-1613.

98 Schifferli D.M., E.H.Beachey. Bacterial adhesion: modulation by antibiotics which perturb protein synthesis. Antimicrob Agents Chemother 1988; 32: 1603-1608.

99 Sugarman B., T.Donta. Effect of antibiotics on the adherence of Enterobacteriaceae to human buccal cells. J Infect Dis 1979; 140: 622-625.

100 Sandberg T., K. Stenqvist, C. Svanborg-Eden. Effects of subminimal concentrations of ampicillin, chloramfenicol, and nitrofurantoin on the attachment of Escherichia coli to human uroepithelial cells in vitro. Rev Infect Dis 1989; 1: 838-844.

101 Shibl A.M. Effect of antibiotics on adherence of microorganisms to epithelial cell surfaces. Rev Infect Dis 1985; 7: 51-65.

102 Väisänen V., K.Lounatmaa, T.K.Korhonen. Effects of sublethal concentrations of antimicrobial agents on the hemagglutination, adhesion and ultrastructure of pyelonephritogenic Escherichia coli strains. Antimicr Agents Chemother 1982; 22:120-127.

103 Ofek I., E.H.Beachey, B.I.Eisenstein, M.L.Alkan, N.Sharon. Suppression of bacterial adherence by subminimal inhibitory concentrations of B-lactam and aminoglycoside antibioics. Rev Infect Dis 1979; 1: 832837.

104 Washington J.A. The effects and significance of subminimal inhibitory concentrations of antibiotics Rev Infect Dis 1979;1: 781-786.

105 Ben Redjeb S., A.Slim, A. Horchani, S.Zmerilli, A. Boujnah, V.Lorian. Effects of ten milligrams of ampicillin per day on urinary tract infections. Antimicrob agents Chemother 1982; 22: 1084-1086.

106 Nicolle L.E. Efficacy of five years of continuous low dose trimethoprim-sulfamethoxazole prophylaxis for urinary tract infection. I Infect Dis 1988; 157: 1239-1241.

107 Chopra I., A.Linton. The antibacterial effects of low concentrations of antibiotics. Adv Microbiol Physiol 1986; 28:211-259. 
108 Zhanel G.G., L.E.Nicolle. Effect of subinhibitory concentrations (sub. MICs) on in-vitro bacterial adherence to uroepithelial cells. Chemotherapy $1992 ; 29: 617-627$.

109 Dean E.A., R.E.Kessler. Quantitation of effects of subinhibitory cconcentrations of trimethoprim on $\mathbf{P}$ fimbriae expression and in vitro at dhesiveness of uropathogenic Escherichia coli. J Clin Microbiol 1988; 26: 25-30.

110 Kovarik J.M., I.M.Hoepelman, J.Verhoef. Influence of fluoroquinolones on expression and function of $\mathrm{P}$ fimbriae in uropathogenic Escherichia coli. Antimicrob Agents Chemother 1989; 33: 684-688.

111 Bosch van den J.F. Virulence of Escherichia coli in urinary tract inffections. Thesis, Free University of Amsterdam 1981. Krips Repro Mleppel.

112 Courcol R.J., P.A.Lambet, P.Fournier, G.R.Martin, M.R.

W.Brown. Effects of iron depletion and subinhibitory concentrationss of antibiotics on siderophore production by Staphylococcus aureus. J Antimicr Chemother 1991; 28: 663-668.

113 LeVatte M.A., P.A.Sokol. Effects of sub-inhibitory concentrations ${ }^{3}$ of antibiotics on surface expression of ferripyochelin binding protein in Pseudomonas aeruginosa. I Antimicr Chemother 1989; 24: 881-895.

114 Morris G., M.R.W.Brown. Novel modes of action of aminoglycosiide antibiotics against Pseudomonas aeruginosa The Lancet 1988; 1359-61.

115 Kadurugamuwa J.L., H.Anwar, M.R.W.Brown, O.Zak.Effect of subinhibitory concentration of cephalosporins on surface properties a and siderophore production in iron-depleted Klebsiella pneumoniae. Anttimicr Agents Chemother 1985; 27: 220-223. 
CHAPTER II

ANTIBIOTIC SUSCEPTIBILITY PATTERNS OF UROPATHOGENS ISOLATED FROM GENERAL PRACTICE PATIENTS FROM THE SOUTH OF THE NETHERLANDS. 


\section{SUMMARY}

In the present study the antibiotic susceptibilities of nearly 1200 uropathogens isolated from general practice patients from the south of the Netherlands were determined. The lowest susceptibility rates of Escherichia coli were observed to amoxycillin and sulfamethoxazole (60 and $78 \%$ respectively), the highest for norfloxacin and fleroxacin (100\%).

All but one amoxycillin resistant strain were susceptible to the combination of amoxycillin + clavulanic acid. Also nitrofurantoine susceptibility was rather high (93\%) in Escherichia coli. Most of the trimethoprim resistant strains $(79 \%)(\mathrm{MIC}>8 \mu \mathrm{g} / \mathrm{ml})$ were high level resistant (MIC $\geq 512$ $\mu \mathrm{g} / \mathrm{ml}$ ). Colony blot hybridization revealed the presence of DHFR type I and type $\mathrm{V}$ in $92 \%$ and $8 \%$ of those strains respectively.

The decrease in antibiotic susceptibilities over time, as demonstrated in an additional analysis of research reports over the period 1971-1991, and the seasonal variations in susceptibility warrant the participation in surveillance systems to monitor the antibiotic resistance of in- and outpatient isolates.

\section{INTRODUCTION}

Urinary tract infection (UTI) is a very common disease, especially in women. The incidence of UTI increases strikingly in young women during late adolescence ${ }^{1,2}$. Between 16 and 35 years one out of five women has at least one episode of acute cystitis each year, making UTI the most frequent infection in this age group. Of all oral antibiotics prescribed by general practitioners $11 \%$ are for the treatment of UTI and this represents therefore, an important group of infections treated with antimicrobial agents ${ }^{3}$.

For the treatment of UTI the antimicrobial agent should be active to the likely uropathogens and minimally disrupt the normal gut and perineal fllora ${ }^{4}$. In general practice patients, antibiotic therapy is mainly empiric. Although high in-vitro and in-vivo activity of several antimicrobial agents has been described by several authors, also increased resistance of uropathogens was observed ${ }^{5}$. In addition, differences in antibiotic susceptibility of pathogens from in- and outpatients as well as differences between regions in the same country have been reported ${ }^{3,5,6}$. To provide the general practitioner with antimicrobial susceptibility data one has to be careful to extrapolate data from the nearby hospital or from other institutions or regions to the outpatient populations of the general practitioner. Adequate epidemiological data on antibiotic susceptibility of uropathogens of outpatients will support the empiric therapy of general practice. In the Netherlands, however, only 
limited data are available on antibiotic susceptibility on general practice isolates. In 1988407 Escherichia coli strains isolated from general practice patients were investigated in the south of the Netherlands ${ }^{8}$ and in 1990149 uropathogens were tested at the National Institute of Public Health and Environmental Hygiene?

In the present study the antibiotic susceptibility of uropathogens isolated from patients in the south of the Netherlands attending their general practitioner was determined. In addition, the mechanism of resistance to amoxycillin and trimethoprim in Escherichia coll isolates was analyzed.

\section{MATERIALS AND METHODS}

\section{BACTERIAL STRAINS}

The strains $(n=1181)$ were isolated from consecutive patients consulting the general practitioner with complaints of UTI. A urine sample was considered to be positive if $\geq 10^{5}$ colony forming units (CFU) per $\mathrm{ml}$ of one species were found using the streak plate method. The microorganisms isolated were identified by means of standlard bacteriological methods, including the Analytic Profile Index (API20E) (API Monterieux, France) system for Enterobacteriaceae.

SUSCEPTIBILITY ASSAY

The antibiotic susceptibility tests were performed as a microbroth dilution method using an inoculum of $10^{5} \mathrm{cfu} / \mathrm{ml}$ in ISO sensitest broth (Oxoid CM 473) prepared by dilution of a fresh overnight broth culture. The minimum inhibitory concentration (MIC) was defined as the lowest concentration of the antimicrobial agent at which no visible growth was apparent after 18-24 hr of incubation at $37^{\circ} \mathrm{C}$. Escherichia coli ATCC 25922 was used as the reference strain.

\section{ANTTMICROBIAL AGENTS}

The antimicrobial agents used were kindly provided by their respective manufacturers. The breakpoints for determining resistance were according to the guidelines of the Dutch Working Party on Antimicrobial Susceptibility Testing: amoxycillin $>32 \mu \mathrm{g} / \mathrm{ml}$, amoxycillin + clavulanic acid $(2: 1)>32$ $\mu \mathrm{g} / \mathrm{ml}$, sulfamethoxazole $>128 \mu \mathrm{g} / \mathrm{ml}$, trimethoprim $>8 \mu \mathrm{g} / \mathrm{ml}$, co-trimoxazole $>8 \mu \mathrm{g} / \mathrm{ml}$, nitrofurantoine $>32 \mu \mathrm{g} / \mathrm{ml}$, norfloxacin $>8 \mu \mathrm{g} / \mathrm{ml}$, and fleroxacin $>8 \mu \mathrm{g} / \mathrm{ml}$.

\section{B-LACTAMASE DETERMINATION.}

The characterization of the type of B-lactamase produced was performed as described earlier ${ }^{9}$. In short, an overnight culture was diluted $1: 10$ in Nutrient broth (Oxoid CM67) and incubated, while shaking at $37^{\circ} \mathrm{C}$. After 4 
$\mathrm{h}$ of incubation the cells were collected by centrifugation, washed once with $0.01 \mathrm{M}$ phosphate buffer $(\mathrm{pH} 7.0)$, suspended in the same buffer and ultrasonicated. The broken cells were centrifuged at $10,000 \mathrm{~g}$ for $30 \mathrm{~min}$ at $4{ }^{\circ} \mathrm{C}$ and the supernatant was used as the crude enzyme extract and stored at $20^{\circ} \mathrm{C}$ until use.

The concentration of protein was estimated by the method of Biorad with bovine serum albumin as the standard ${ }^{10}$.

For the B-lactamase characterization, analytical isoelectric focusing was performed in polyacrylamide gels containing Pharmalyte in the $\mathrm{pH}$ range 310 using nitrocefin as indicator according to the method of Matthew .

CHARACTERIZATION OF TRIMETHOPRIM RESISTANT STRAINS

$(M I C \geq 512 \mathrm{mg} / \mathrm{l}$ )

Plasmid DNA was isolated by the method of Sambrook ${ }^{11}$. Two probes encoding trimethoprim resistance were used: one was a $0.49 \mathrm{~kb} \mathrm{KpnI} / \mathrm{BamHI}$ fragment of pLKO627 encoding for the dhfrI gene and the other was a 0.49 $\mathrm{kb}$ Hpal fragment of pLKO22 encoding for the dhfrV gene ${ }^{12,13}$. (The probes used were kindly provided by L.Sündströrn). The probes were labeled with digoxigenin according to the manufacturers instructions (Boeringer Mannheim, Mannheim, Germany).

Colony blot hybridization on nylon membranes (Nytran) was performed according to the manufacturers instructions (Nytran, Schleicher \& Schuell, Den Bosch, the Netherlands). Prehybridization and hybridization were done under stringent conditions at $42^{\circ} \mathrm{C}$ in formamide $50 \%, 5 * \mathrm{SSC}(0.75 \mathrm{M}$ sodiumchloride, $0.075 \mathrm{M}$ sodiumcitrate), sarcosyl (n-laurylsarcosine) $0.1 \%$, SDS (sodium dodecylbisulfate) $0.02 \%$, salmon sperm $0.5 \%$ and blocking reagent 2\% (Dig kit, Boeringer Mannheim, Mannheim, Germany) with washes in $2 * \mathrm{SSC}$ and $0.1 \%$ SDS at $68^{\circ} \mathrm{C}$ and in $1 * \mathrm{SSC}$ and $0.1 \% \mathrm{SDS}$ at room temperature.

Detection of digoxigenin labeled nucleic acids, using positive (strains pLKO267 and pLKO22) and negative (strain HB101) controls, was performed by chemoluminescence on radiographic films (Kodak X omat AR).

\section{RESULTS}

Of the 1181 uropathogens isolated, $79 \%$ were Escherichia coli $(\mathrm{n}=$ 934), followed by $7.5 \%$ coagulase negative staphylococci $(n=89)$ and $6.8 \%$ Proteus spp $(\mathrm{n}=81)$. Other Enterobacteriaceae were isolated with a frequency of $5.1 \%(n=58)$. The rest $1.6 \%(n=19)$ were other bacteria.

The antibiotic susceptibility of the strains tested is shown in table 1 . The positive effect of clavulanic acid on the susceptibility to amoxycillin of 
Table I ANTIBIOTIC SUISCEPTIBILITIES OF UROPATHOGENS ISOLATED FROM GENERAL PRACTICE PATIENTS

$\mathrm{MIC}(\mathrm{MG} / \mathrm{L})$

BACTERIAL SPECIES AND ANTIBIOTIC (NUMBER OF ISOLATES)

RANGE

GEOM

SUSCEPTIBILTTES

$M_{\text {IC }}, \mathrm{MIC}_{90}$ MEAN

$\leq 0.062->256$

$\leq 0.062-256$

$\leq 0.062->256$

$\leq 0.062->256$

$\leq 0.062->256$

$\$ 0.25>1024$

$50,062->8$

$\$ 0.031-8$

$\leq 0.062->256$

$\leq 0.062-256$

$\leq 0.062->256$

$\leq 0.062->256$

$\leq 0.062->256$

$\leq 0.25->1024$

$\leq 0.062-8$

$50.031-8$

$\leq 0.062->256$

$\leq 0.062-64$

$\leq 0.062-256$

$\leq 0.062->256$

$\leq 0.062->256$

$50.062-8$

$\leq 0.031-8$

$\leq 0.062 \sim>256$

$\leq 0.062-256$

$\leq 0.062->256$

$\leq 0.062->256$

$\$ 0.062->256$

$\leq 0.25->1024$

$\leq 0,062,4$

$\$ 0.031-8$

$\begin{array}{rrrr}8 & 256 & 12.3 & 62 \\ 2 & 8 & 2.4 & 99 \\ 16 & 256 & 19.0 & 80 \\ 0.25 & 64 & 0.7 & 87 \\ 0.5 & 256 & 1.0 & 86 \\ 4 & 128 & 6.1 & 88 \\ 0.062 & 0.125 & 0.2 & 100 \\ 0.031 & 0.5 & 0.1 & 100\end{array}$

Staphylococci spp. (89)

amoxycillin + clavulanic actid sulphamethoxazole.

co-rimoxazole nitrofurantoine norfloxacin

neroxacin

$\begin{array}{rrr}1 & 256 & 2.2 \\ 0.25 & 2 & 0.3 \\ 8 & 128 & 9.8 \\ 0.5 & 32 & 1.0 \\ 0.5 & 8 & 0.9 \\ 4 & 16 & 5.2 \\ 0.125 & 1 & 0.2 \\ 1 & 4 & 0.8\end{array}$

* Proteus spp. are not included 
Figure I MICS OF ALL UROPATHOGENS AND ESCHERICHA COLI ISOLATES TESTED TO EIGHT ANTIMICROBIAL AGENTS. (UPPER ALL UROPATHOGENS, LOWER ESCHERICHA COL)
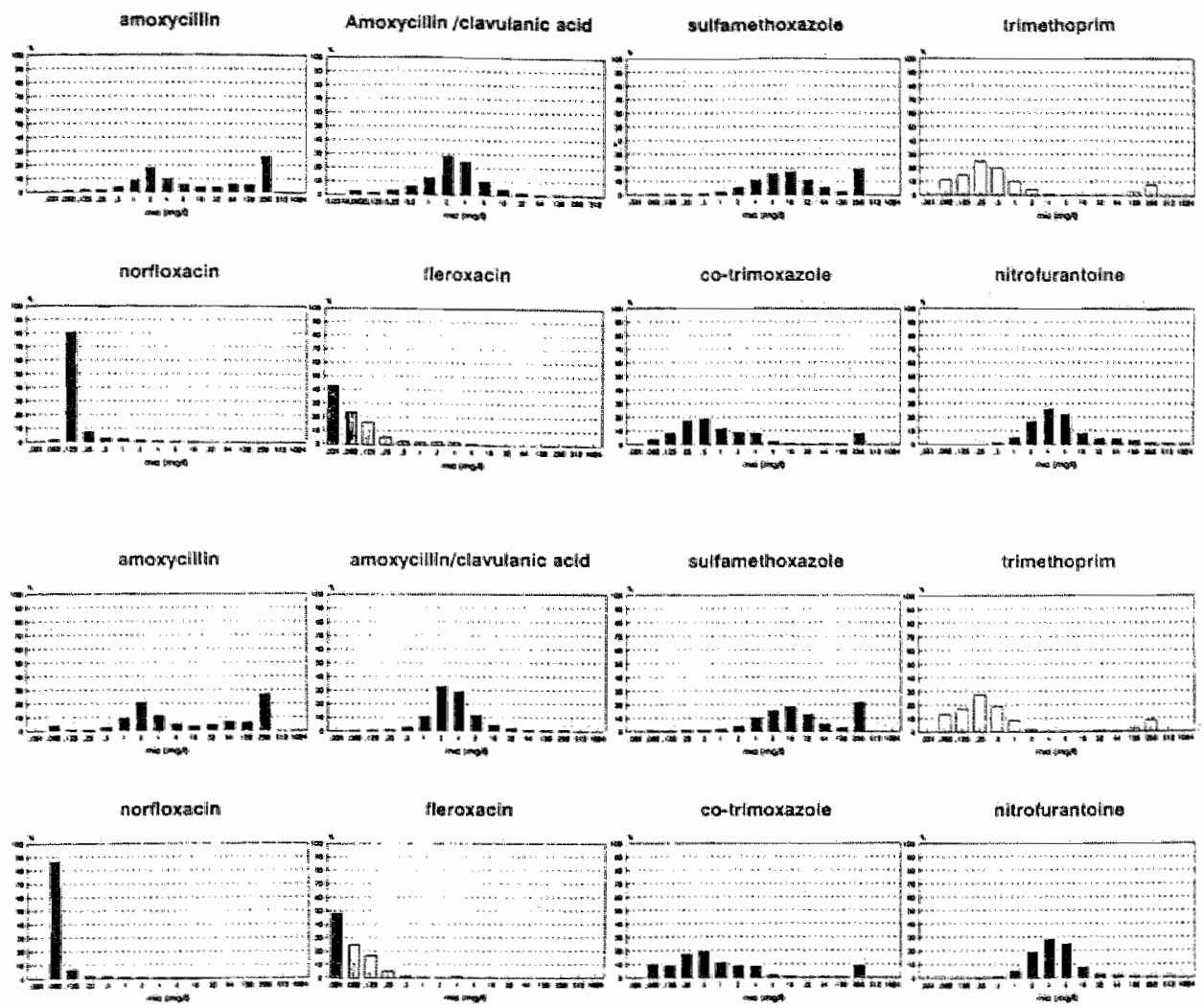

strains was quite obvious. The geometric mean of amoxycillin alone was 12.3 and of the combination $2.4 \mu \mathrm{g} / \mathrm{ml}$. The same pattern applied to the antibacterial activity of the combination of sulfamethoxazole and trimethoprim (cotrimoxazole) compared to the activity of sulfamethoxazole alone. Both quinolones, norfloxacin and fleroxacin, were highly active to all strains tested: $90 \%$ of the strains were inhibited by $0.5 \mu \mathrm{g} / \mathrm{ml}$ or less although fleroxacin tended to be slightly less active than norfloxacin (figure 1 ). The resistance of Escherichia coli isolates to amoxycillin (40\%) was distinctly 
higher than to sulfamethoxazole (22\%).

From all bacteria isolated $(n=1181)$, resistance to three or more antimicrobial agents was observed in $144(12.2 \%)$ strains, 487 strains $(41.2 \%)$ were susceptible to all agents tested. From the Escherichia coli isolated $(\mathrm{n}=938) 86(9.2 \%)$ were resistant to three or more antimicrobial agents, $438(46.7 \%)$ were fully susceptible. (Table 2 )

Table II MULTIPLE RESISTANCE TO ALL BACTERIA ISOLATED AND TO ALL ESCHERICHLA COLIISOLATED.

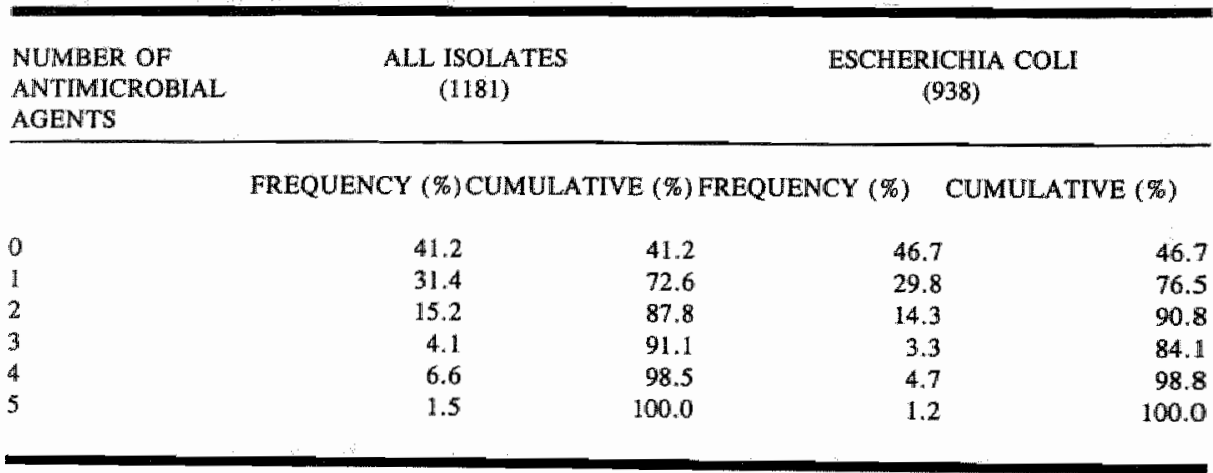

All but one amoxycillin resistant Escherichia coli $(\mathrm{n}=933)$ were susceptible to amoxycillin in combination with clavulanic acid and were found to have a TEM-1 plasmid-mediated resistance. The only Escherichia coli resistant to the combination of amoxycillin + clavulanic acid produced two $B$ -lactamases, a TEM-1 $(\mathrm{pI}=5.2)$ and a second enzyme with a pI of 9.0. The relatively low basal enzyme activity increased more than tenfold after induction. This and the high pl strongly suggests that the second enzyme is a chromosomal encoded B-lactamase.

High level trimethoprim resistance (MIC $\geq 512 \mu \mathrm{g} / \mathrm{ml}$ ) was observed in $79 \%(\mathrm{n}=75)$ of all trimethoprim resistant Escherichia coli. Further characterization using the same probes as were described previously revealed that $69(92 \%)$ strains harbored a type I mediated resistance and one strains a type V $(1 \%)$ mediated resistance.

\section{DISCUSSION}

In the present study the antibiotic susceptibility of nearly 1200 uropathogens was determined. The susceptibility to those compounds especially used for the treatment of UTI (trimethoprim, nitrofurantoine, co-trimoxazole 
and norfloxacin) was rather high $(88 \%-100 \%)$.

The susceptibility to sulfamethoxazole and amoxycillin was quite remarkable. A study performed in the Netherlands in the same region with almost the same general practitioners revealed a susceptibility to sulfamethoxazole and amoxycillin of $71 \%$ and $84 \%$ compared to $78 \%$ and $60 \%$ respectively in the present study ${ }^{7}$. Thus no decrease in susceptibility to sulfomethoxazole (rather a slight increase), however a distinct decrease in amoxycillin susceptibility was observed in a two year period.

"Tabll HI ANTIBIOTIC SUSCEPTIBILITIES OF ISOLATES OF" GENERAL PRACTICE.

\begin{tabular}{llllll} 
SURVEY & NUMBER YEAR COUNTRY & \multicolumn{3}{c}{ ANTIMICROBIAL AGENTS } \\
& OF & & & & \\
& ISOLATES & AMP AUG SUL TRI COT NIT NOR
\end{tabular}

ESCHERICHIA COLI

Gruneberg
Abbas $^{54}$
Beale $^{14}$
Gruneberg $^{5}$
Baselier $^{2}$
Stobberingh
de Neeling"
Trienekens
(this study)

$\begin{array}{rrrrrrrrrr}340 & 1971 & \text { GB } & 91 & - & 77 & 99 & 99 & 98 & - \\ 960 & 1979 & \text { GB } & 71 & 89 & - & - & 87 & - & - \\ 34734 & 1984 & \text { GB } & 67 & 93 & 63 & 86 & 83 & 93 & - \\ 1543 & 1989 & \text { GB } & 66 & - & 67 & 82 & 83 & 97 & - \\ 121 & 1983 & \text { NETH } & 87 & - & 35 & - & - & 89 & - \\ 407 & 1988 & \text { NETH } & 84 & 96 & 71 & 90 & 91 & 98 & 110 \\ 149^{3} & 1990 & \text { NETH } & 66 & 95 & 55 & 76 & 76 & 97 & 99 \\ 938 & 1991 & \text { NETH } & 60 & 97 & 78 & 88 & 88 & 93 & 100\end{array}$

ALL UROPATHOGENS ISOLATED

Grunebergs

Nabertis

Trienekens

(this study)

$\mathrm{G}=\mathrm{Gr}=\mathrm{neat}$ Britain

NETH $=$ the Netheriandis:

GER = Gurmany

"AMP" $=$ amoxycillin

AUOS $=$ amoxycillin + clavulanic acid

SUL $=$ sulphamethoxazole

TRI = trimethoprim

COT $=$ co-trimoxaxole

NIT $=$ mitrofurantoine

NOR $=$ norfloxach

${ }_{1.2}$ bacteria were not derived from arite samples

$\begin{array}{rr}433 & 1971 \\ 2129 & 1989 \\ 349 & 1990 \\ 1181 & 1991\end{array}$

$\begin{array}{rr}\text { GB } & 88 \\ & 62 \\ \text { GER } & 90 \\ \text { NETH } & 62\end{array}$

90

$\begin{array}{rr}76 & 94 \\ 67 & 83 \\ - & 94 \\ 80 & 87\end{array}$

$\begin{array}{lr}97 & 86 \\ 84 & 88 \\ 95 & - \\ 86 & 88\end{array}$

86

88

88

100 
Comparing the results of different studies, in Great Britain a decrease in susceptibility to both compounds is observed (table 3) $2,5,7,8,14,15,16$. The antimicrobial activity of amoxycillin in combination with clavulanic acid was very high, almost all amoxycillin resistant strains were susceptible to this combination. Over time no decrease in susceptibility is observed. Also the susceptiblity of nitrofurantoine remained stable over time. Neither in Great Britain nor in the Netherlands a decrease was observed, despite the use of this antimicrobial agent in for at least 35 years.

Trimethoprim susceptibility is still at a fairly stable level $(88 \%)$. However, it was remarkable that the combination of trimethoprim with sulfamethoxazole had the same susceptibility $(88 \%)$. Thus no synergistic effect of trimethoprim with sulfamethoxazole was observed in this study. Therefore the use of trimethoprim as a single agent for the treatment of UTI is highly recommended. Sulfamethoxazole only adds to the side effects but does not increase the antibacterial activity if used in combination with trimethoprim ${ }^{17}$.

Comparing the trimethoprim resistance in the present study with that of the study of Heikkilä ${ }^{18}$ some differences could be observed. The overall resistance was $12 \%$ and $40 \%$ respectively. High level resistance in these strains was $79 \%$ and $97 \%$ respectively and the percentage of type I DHFR $92 \%$ and $79 \%$ respectively of these high level resistant strains.

The higher percentages of trimethoprim resistance in Finland might be due to the higher use of trimethoprim compared to that in the Netherlands ${ }^{18}$. The source of the isolates, outpatients or isolates from geriatric units or hospital strains might play a role as well. In another study in 1985 comprising 19 Escherichia coli strains a type I DHFR could be demonstrated in $15(79 \%)$ of the high level resistant isolates ${ }^{19}$.

Vorland ${ }^{20}$ described a seasonal dependence in incidence and prevalence of antimicrobial resistance. In the present study no seasonal variation was observed. The mean number of monthly isolates was 43.3 (sd 19.2). In addition the monthly prevalence of resistance to sulfamethoxazole, amoxycillin and nitrofurantoine was rather stable during the study period (figure II).

Not only differences over time, differences between regions within one country are important as well. Also in the Netherlands differences over time were as important as the differences in susceptibility between different regions. Susceptibility percentages to sulfamethoxazole in general practice uropathogens isolated in three regions (east, middle and south) were $35 \%$, $55 \%$, and $78 \%$ respectively. The lowest percentage of susceptibility were found in a study in the east of the Netherlands ${ }^{2}$, the highest susceptibility 
rates were found in the present one (1991).

Figure II PERCENTAGE OF MONTHLY ISOLATED ESCHERICHIA COLI STRAINS RESISTANT TO SULPHAMETHOXAZOLE.

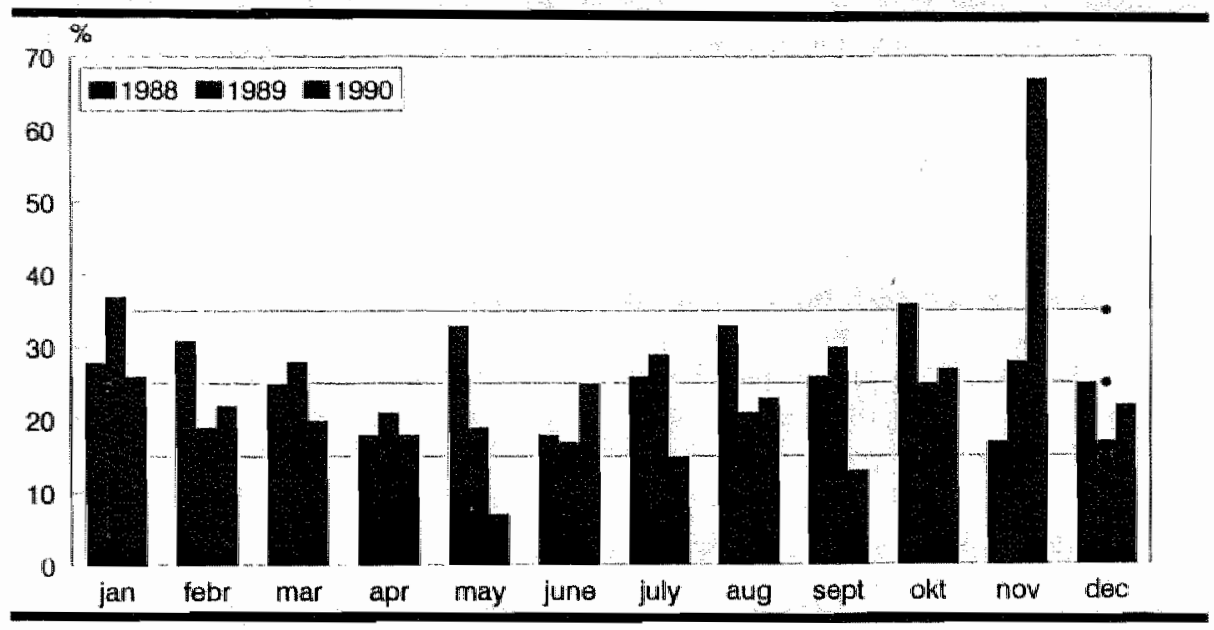

It might be possible that the differences in susceptibility are due to differences in antibiotic presciption in the different regions. Unfortunately, no data on the use of antibiotics by general practitioners are available.

In conclusion the recommendations of the Infectious Disease Society of America as to the need for surveillance of out- and in-patient isolates to provide the medical doctor with up to date data on antibiotic susceptibility are underscored with our data ${ }^{21}$. 


\section{REFERENCES}

1 Valkenburg H.A. (1987) Epidemiology of urinary tract infections. European Urology 13 suppl.1 5-8.

2 Baselier P.J.M. (1983) Acute bacteriêle urineweginfecties in de huisartspraktijk. Thesis Nijmegen, Krips Repro, Meppel

3 Friis H., F.Bro, C.E.Mabeck and R.Vejlsgaard: Use of antibiotics in general practice in Denmark in 1987. Scandinavian Journal of Infectious Diseases (1989) 21 551-556.

4 Moss F.M., M.W.McNicol, D.A.McSwiggan, D.L.Miller: Survey of antibiotic prescribing in a district general hospital. III Urinary tract infection. The Lancet, August 29 (1981) 461-462.

5 Gruneberg R.N.: Changes in the antibiotic sensitivities of urinary pathogens, 1971-1989. Journal of Antimicrobial Chemotherapy (1990) 26 Suppl F 3-11.

6 O'Brien I.F.: The International Survey of Antibiotic Resistance Group; Resistance to antibiotics of medical centers in different parts in the world. Journal of Antimicrobial Chemotherapy (1986) 18 243-253.

7 Neeling de A.J., J.deJong, B.P.Overbeek, R.W.deBruin, M.Dessens-Kroon, B.van Klingeren: Kwalitatief gevoeligheidsonderzoek met intra- en extramurale isolaten van Escherichia coli Rapport R.I.V.M. (1990) no. 359001002.

8 Stobberingh E.E., A.W.Houben: Antibioticagebruik en antibioticaresistentie in de huisartspraktijk. Nederlands Tijdschrift voor geneeskunde (1990) 132 1793-1797.

9 Matthew M., A.M.Harris, M.J.Marshall, G.W.Ross: The use of analytical isoelectrical focusing for detection and identification of Blactamases. Journal of General Microbiology (1975) 88 169-178.

10 Lowry O.H.N., N.J.Rosebrough, A.L.Farr and R.J.Randall: Protein measurement with the Folin phenol reagent. Journal of Biological Chemistry (1951) 193 265-275.

11. J.Sambrook, E.F.Fritsch, and T.Maniatis: Molecular cloning: a laboratory manual. 2nd ed (1989). Cold Spring Harbor Laboratory, Cold Spring Harbor, N.Y.

12 Sündström L., P.Rådström, G.Swedberg, O.Sköld: Site-specific recombination promotes linkage between trimethoprim and sulfonamide resistance genes. Sequence characterization of $\mathrm{dhfrV}$ and sullI and a recombination active locus of Tn21. Molecular Genes and Genetics (1988) 213 191-201.

13 Sündström L., O.Sköld: The dhfrl trimethoprim resistance gene of 
Tn7 can be found at specific sites in other genetic surroundings. Antimicrobial Agents and Chemotherapy (1990) 34 642-650.

14 Abbas AMA, B Ahattopadhyay, C Dulake: A multicenter antibiotic sensitivity survey of general practice and hospital strains. Proceedings of the 1st symposium on Augmentin:clavulanate potentiated amoxycillin 1980: 173-183.

15 Beale AS, R Sutherland: Antibiotic sensitivity of urinary isolates from general practice in Great-Britain in 1984- a multicentre study. Proceedings of 6th Mediterranean Congress of Chemotherapy 1988.

16 Naber K.G., U.Thyroff-Friesinger: Susceptibility of pathogens causing acute uncomplicated urinary tract infection in females. Presented at 5th European Congress of Clinical Microbiology and Infectious Diseases (1991), Oslo, Norway, p 189.

17 Kunin CM (ed): Detection, prevention and management of urinary tract infections (1987) 4th edition. Lea and Febiger Philadelphia USA.

18 Heikkilä E., L.Sündström, P.Huovinen: Trimethoprim resistance in Escherichia coli isolates from a geriatric unit. Antimicrobial Agents and Chemotherapy (1990) 34 2013-2015.

19 Steen R., O.Sköld: Plasmid-borne or chromosomally mediated resistance by $\operatorname{Tn} 7$ is the most common response to ubiquitous use of trimethoprim. Antimicrobial Agents and Chemotherapy (1985) 27 933-937.

20 Vorland L.H., K.Carlson, O.Aalen: Antibiotic resistance and small R plasmids among Escherichia coli isolates from outpatient urinary tract infection in northern Norway. Antimicrobial Agents and Chemotherapy (1991) 27 107-113.

21 Marr J.J., H.L.Moffet, C.M.Kunin:: Guidelines for improving the use of antimicrobial agents in hospitals: a statement by the Infectious Diseases Society of America. The Journal of Infectious Diseases (1988) $157869-876$. 
CHAPTER III

DIFFERENT LENGHTS OF TREATMENT

WITH CO-TRIMOXAZOLE FOR ACUTE UNCOMPLICATED URINARY TRACT INFECTIONS IN WOMEN. 
40 


\section{ABSTRACT}

Study abjective - To compare a 3 days and 7 days course with cotrimoxazole in women with acute dysuria, stranguria, urinary frequency or urgency.

Design - Randomized, double blind placebo controlled trial.

Setting - General practices in the south east of The Netherlands.

Patients - 327 Non-pregnant female patients aged 12 to 65 .

Intervention - 161 Women were allocated to 3 days treatment (cotrimoxazole $960 \mathrm{mg}$ twice a day) 166 women were allocated to 7 days treatment (cotrimoxazole $960 \mathrm{mg}$ twice a day).

Main outcome measure - The rates for resolution of symptoms were not significantly different between the two groups. Cumulative rates of recurrence after 3 days and 7 days treatment were $31 / 139(22 \%)$ and $23 / 151$ $(15 \%)$ respectively six weeks after entry $(p=0.16)$. Adverse effects occurred in a quarter of women given 3 days treatment compared with a third of women receiving 7 days treatment $(p=0.29)$. In only 2 patients did adverse effects necessitate stopping treatment.

Conclusions - 3 days of co-trimoxazole seems to be as effective as a 7 days course for treating acute urinary tract infection in non-pregnant women.

\section{INTRODUCTION}

The prevalence of acute uncomplicated urinary tract infection in women is fairly high at about 50/1000/year ${ }^{1,2}$. The optimal duration of antibiotic treatment, however, remains a point of discussion. Single dose therapy offers several advantages over the conventional duration, including improved compliance, reduced adverse effects, decreased risk on disturbing bacterial flora and selecting resistant microorganisms and lower $\operatorname{costs}^{3,4}$. In the past 20 years several studies have suggested that single dose therapy is as effective as the conventional regimens of 10 or 14 days $s^{5.8}$. No study, however, has included enough patients to prevent the type II error ${ }^{9}$. Freiman et al. ${ }^{10}$ and Fihn et al. ${ }^{11}$, reviewing 71 and 62 clinical studies respectively, concluded that most trials studied too few patients to detect a meaningfull difference between the therapeutic regimens. In a recent study with adequate statistical power no symptomatic difference was observed between a single dose and 10 days course of co-trimoxazoleat 3 and 13 days and 6 weeks after the start of the treatment ${ }^{12}$. Adverse effects, however, were twice as common in the group allocated to 10 days of treatment compared with the patients 
receiving single dose treatment. the authors therefore suggested that an intermediate duration of treatment might be optimal.

We carried out a randomised double blind placebo controlled clinical trial of 3 days versus 7 days of co-trimoxazole for treating acute uncomplicated urinary tract infections in women.

\section{PATIENTS AND METHODS}

Non pregnant female patients aged $12-65$ presenting to their general practioner with either dysuria, stranguria, urinary frequency or urgency in the past 24 hours were included in the study. Patients were excluded if they had signs and symptoms of acute pyelonephritis, were known diabetics, had known structural abnormalities of the urinary tract, had indwelling catheters, had recently received immunosuppressive drugs, were allergic to trimethoprim, sulfamethoxazole or co-trimoxazole, or received antimicrobial treatment within the previous 4 weeks. Patients with a known urinary tract infection within the past 3 months were also excluded. Informed consent was obtained from all participants before enrolment.

Patients were assigned in a random and double blind way to receive either 3 days of co-trimoxazole $960 \mathrm{mg}$ twice a days followed by 4 days of placebo twice a days (3 days regimen) or 7 days co-trimoxazole $960 \mathrm{mg}$ twice a days ( 7 days regimen). Blinding was achieved with the double dummy technique by using placebo tablets that looked identical to the active tablets (Bactrimel Forte ${ }^{R}$ ).

Clean voided urine specimens were obtained from all patients for standard quantitative and dip-slide culture (Orion Diagnostics, Espoo, Finland) and antimicrobial susceptibility tests. For isolating microorganisms standard laboratory methods were used. Bacterial counts were performed by the quantitative surface streak technique using a $0.03 \mathrm{ml}$ standard drop on to $7 \%$ sheep blood agar and MacConkey agar plates. The isolated microorganisms were identified by standard bacteriological methods that included the analytic profile index (API Montalieu-Vercieu, France) for Enterobacteriaceae. Coagulase negative staphylococci resistant to novobiocin were identified as Staphylococcus saprophyticus. Escherichia coli serotyping (for $O$ and $K$ antigens) was performed in cooperation with the National Institute for Public Health and Environmental Hygiene, Bilthoven (dr. Guinée) on the initial and subsequent isolates from most patients whose follow up cultures yielded positive results for Escherichia coli. The $\mathrm{O}$ and $\mathrm{K}$ antigens were identified by bacterial agglutination. Urine samples containing more than two species of bacteria were considered to be contaminated and not 
included in the analysis. The presence of growth inhibiting factors was detected by using a Bacillus subtilis as an indicator strain.

All patients were asked to return to their general practitioner one, two and six weeks after enrolment. On return visits they filled in a questionaire about relieve of symptoms and possible antimicrobial side effects such as headaches, nausea, vomiting or diarrhoea. In addition, clean voided urine specimens were obtained at each follow up visit and processed in the same way as the initial specimen. Severe side effects were defined as those that needed treatment or that would preclude treatment with co-trimoxazole in the future. From some patients a urine sample was obtained without the questionnaire so the total number of patients for whom data on symptoms and bacteriological response were available were different.

Patients were diagnosed as having an urinary tract infection if they presented with acute dysuria, stranguria or urinary frequency or urgency, and a bacterial colony count $\geq 10^{5} \mathrm{cfu} / \mathrm{ml}$. The effectiveness of therapy was based on the short and long term effect of cure, persistence, relapse and reinfection ${ }^{11}$. Persistence was defined as presence of the causative organism in the urine after treatment had stopped and relapse as the absence of the organism at or after the end of treatment but reappearance of the same organism in the 2 weeks (early relapse) or 6 weeks (late relapse) after enrolment. Reinfection was defined as appearance of another infecting organism in the 1 or 2 weeks (early reinfection) or 6 weeks (late reinfection) after enrolment, whereas cure was defined as absence of the causative organism at and during follow-up. Failure of treatment was defined as all cases of persistence, relapse and reinfection as well as those cases of persistence of symptoms or occurence of adverse drug reactions for which the doctor had to prescribe another drug. Unassessable cases were those for which evaluating bacteriological response was not possible, because no follow up cultures were obtained ${ }^{13}$.

Based on data from our pilot study ${ }^{14}$ bacteriuria will be eradicated in $90 \%$ of women treated with co-trimoxazole $960 \mathrm{mg}$ twice a day. We took a $10 \%$ increase in effectiveness of 7 days'treatment over 3 days' to be the minimum; less would not be clinically meaningful because of the lower costs, greater compliance of patients, and fewer adverse effects associated with shorter treatment. Our null hypothesis was that both treatment with 3 days'and 7 days" co-trimoxazole would be successful in $90 \%$ of the patients, and assuming a significance of $\mathrm{p} \leq 0.05$ and a power of $80 \%$ we calculated that we required 142 patients for each treatment group ${ }^{15,16}$. The comparisons of treatment regimens and differences in the prevalence of adverse reactions were determined by $\chi^{2}$ analysis. 


\section{RESULTS}

Nineteen general practitioners from the south east of The Netherlands participated in the study. From January 1988 till April 1989, 327 women were enrolled in the study: 161 received a 3 days' treatment and 166 a 7 days' treatment. The mean (SD) ages of both the two groups were $35.0(4.6)$ and 38.4 (5.4) years respectively. Follow-up cultures at 1,2 and 6 weeks were obtained from $145(90 \%), 132(82 \%)$ and $139(86 \%)$ patients receiving the short treatment course $152(92 \%), 136(82 \%)$ and $151(91 \%)$ patients receiving the long term treatment respectively.

Table I NUMBERS (PERCENTAGES) OF PATIENTS WTTH URINARY PATHOGENS BEFORE TREATMENT WITH CO-TRIMOXAZOLE.

\begin{tabular}{lrr}
\hline & LENGTH OF TREATMENT \\
URINARY PATHOGENS & $\begin{array}{r}\text { 3 DAYS } \\
\text { (N=161) }\end{array}$ & 7 DAYS \\
& $(\mathrm{N}=166)$ \\
\hline Escherichia coli & $90(56)$ & $83(50)$ \\
congulase negative staphylococei & $9(6)$ & $12(7)$ \\
Proteus mirabilis & $6(4)$ & $10(6)$ \\
other Enterobacteriaceae & $6(4)$ & $6(4)$ \\
Staphylococcus aureus & & $2(1)$ \\
negative & $48(30)$ & $53(32)$
\end{tabular}

Table II RESPONSE OF SYMPTOMS IN PATIENTS WITH URINARY TRACT INFECTION TREATED WITH CO-TRIMOXAZOLE. FIGURES ARE NUMBERS (PERCENTAGES) OF PATIENTS.

\begin{tabular}{lrrrr} 
& \multicolumn{3}{c}{ SYMPTOMS PRESENT } & $\begin{array}{r}\text { SYMPTOMS PRESENT AND } \\
\text { BACTERIOLOGICALLY PROVED }\end{array}$ \\
& $\begin{array}{r}\text { 3 DAYS } \\
\text { TREATMENT TREATMENT }\end{array}$ & $\begin{array}{r}\text { 7 DAYS } \\
\text { TREATMENT }\end{array}$ & TREATMENT \\
\hline $\begin{array}{l}\text { symptoms absent or improved one } \\
\text { week after entry } \\
\text { symptoms absent or improved two } \\
\text { weeks after entry } \\
\text { symptoms absent six weeks after } \\
\text { entry }\end{array}$ & $131 / 142(92)$ & $129 / 145(89)$ & $88 / 97(91)$ & $89 / 97(92)$ \\
& $97 / 116(84)$ & $106 / 123(86)$ & $74 / 85(87)$ & $72 / 80(90)$
\end{tabular}


Table I lists the urinary pathogens isolated. In both treatment groups Escherichia coli was the most commonly isolated pathogen followed by coagulase negative Staphylococci and Proteus mirabilis. Other Enterobacteriaceae isolated were klebsiella, citrobacter and enterobacter. No significant differences were found in the rate of isolation of the uropathogens between the different treatment groups. Table II shows that the proportions of women with acute urinary symptoms whose symptoms were relieved after $\mathbb{1}$, 2 , and 6 weeks were similar in both groups.

Table III CUMULLATIVE RATES OF RECURRENT INFECTIONS IN PATIENTS WTTH URINARY TRACT INFECTIONS TREATED WITH CO-TIMOXAZOLE. FIGURES ARE NUMBERS (PERCENTAGES) OF PATIENTS.

\section{LENGTH OF TREATMENT}

TME AFTER ENROLMENT (WEEKS)

1

$\frac{1}{2}$

$\frac{2}{6}$
3 DAYS

$14 / 145(10)$

$19 / 132(14)$

$31 / 139(22)$
7 DAYS

4/152 (3)

$10 / 136(7)$

23/151 (15)

P VALUE

0.02

0.10

0.16

Table IV NUMBERS OF PATIENTS WITH RECURRENT INFECTION IN PATIENTS WTTH URINARY TRACT INFECTION TREATED WITH CO-TRIMOXAZOLE.

LENGTH OF TREATMENT

TYPE OF FAILURE

persistence

early relapse

early reinfection

lative relapse

latite reintection

3 DAYS

7 DAYS

The cumulative rates of failures were similar in the 2 treatment groups, with a slightly higher but non-significant rate in the patients allocated to the 3 days" treatment (Table III). Table IV gives the classification of the failure of treatment in both groups. In the group allocated to the 3 days' treatment 12 of the 14 Escherichia coli isolates from follow up cultures in cases of persistence and relapse were similar in serotype and antibiotic susceptibility or both to the original infecting microorganism; 2 could not be precisely characterized. The reinfections were caused by Escherichia coli (6), coagulase negative staphylococci (5), Proteus mirabilis (4) and pseudomonas 
(2). The isolated microorganisms differed in species, serotype or antibiogram from the originally infecting strain. Escherichia coli (10), Klebsiella spp (1) and coagulase negative staphylococci (1) were isolated from samples from cases of treatment failure in patients allocated to $(7)$ days' treatment. Eight of the 10 Escherichia coli strains were similar in serotype or antibiotic susceptibility or both to the originally infecting strain. The remaining 2 strains could not be precisely characterized. The klebsiella and coagulase negative staphylococci were both similar in species and antibiogram. Escherichia coli and, coagulase negative staphylococci were isolated 5 times and Streptococcus faecalis only once; they were different in terms of serotype or antibiogram, or both, from the original isolates. Failure of treatment because of resistance to co-trimoxazole occurred in 5 patients allocated to 3 days' treatment and in 4 allocated to 7 days' treatment.

The compliance of the patients was evaluated by using a questionnaire and by testing the urine specimen for the presence of growth inhibiting factors one week after enrolment. Growth inhibiting factors were found in 10 out of the 91 specimens in the group allocated to 3 days' treatment and in 74 of the 101 specimens in the group allocated to 7 days' treatment. Unfortunately, first control specimens taken 1 week after enrolment were not available from all patients.

Table $V$ ADVERSE EFFECT OF TREATMENT WITH CO-TRIMOXAZOLE. FIGURES ARE NUMBERS (PERCENTAGES) OF PATIENTS.

\section{LENGTH OF TREATMENT}

EFFECT

3 DAYS $(\mathbf{N}=161)$

7 DAYS $(\mathbb{N}=166)$

nausea

other gastrointestinal complaints

vinginal aischarge

vash

hesudache

others

totals
$12(7)$
1060
2(1)
$3(2)$
$5(3)$
$8(5)$

$40(25)$
$19(11)$

$15(9)$

1 (I)

$6(4)$

$51(31)$

Subjective adverse effects occurred in 40 patients (25\%) receiving 3 days' treatment compared with $51(31 \%)$ receiving 7 days' treatment $(\mathrm{p}=0.29)$. These included gastro-intestinal upset in $22(14 \%)$ and $34(20 \%)$ patients $(\mathrm{p}=0.137)$ and allergic reactions in $3(2 \%)$ and $6(4 \%)$ patients (Table V). Severe side effects occurred in only two patients (one developed 
rash, one developed gastrointestinal complaints), both of whom had been allocated to 7 days' treatment.

\section{DISCUSSION}

Our study protocol fulfilled the 12 methodological criteria mentioned by Philbrick et al. ${ }^{9}$ and the recommendations of Fihn and Stamm ${ }^{11}$ to be used in clinical trials of treating uncomplicated urinary tract infections in women. Our results showed no difference in symptomatic response up to 6 weeks after enrolment between the different treatment regimens either in the group of patients with a bacteriologically proved urinary tract infection or in the group with acute urinary tract symptoms. A similar clinical response was observed in the study of Gossius and Vorland ${ }^{18}$.

The difference in the rate of bacteriological response 1 week after enrolment might have been due to the presence of growth inhibiting factors in the group allocated to 7 days" treatment, enabling early reinfection to occur. Growth inhibiting compounds were found in 74 of the 101 urine samples from the patients allocated to 7 days" treatment. Early reinfection was observed in 10 patients receiving a 3 days" treatment and in only 2 patients receiving 7 days' treatment. The compliance of the patients allocated to 7 days' treatment was $74 \%$ as indicated by the presence of growth inhibiting factors in the urine samples. This is similar to the $75 \%$ compliance with a treatment regimen of twice a day for about 14 weeks found in the study of Cramer et al. ${ }^{19}$.

Six weeks after enrolment the cure rates in the groups allocated to 3 and 7 days' treatment were $76 \%$ and $83 \%$ respectively. These proprotions were in general lower than those found in other studies $s^{6,8,17,18}$. The difference might have been due to the fairly short follow up period and the different definitions of cure rate used in other studies. We defined cure rate as relief of initial symptoms plus a sterile urine culture throughout the follow up period. Some investigators used the same definitions but included those patients who were reinfected with a different organism, because these patients were cured of the original infection (in our study the so-called re-infections) ${ }^{4}$ $6,8.18$. If we used that definition the cure rates were $90 \%$ and $92 \%$ respectively 6 weeks after enrolment. These rates are slightly higher than found in the study of Finn et al. ${ }^{12}$ but lower than those described by Gossius and Vorland $^{18}$.

An important issue for the patient is relieve of symptoms. Most patients showed relieve after 1 week. After 6 weeks most patients were still free of symptoms in both treatment groups. In 9 out of 31 bacteriological 
fallures in the group allocated to 3 days' treatment and 5 out of 23 bacteriological failures in the group allocated to 7 days' treatment, however, the infection was also symptomatic. In the other patients the infection was asymptomatic. In the bacteriologically cured group 2 patients allocated to 3 days' treatment and 3 in the group allocated to 7 days' treatment still had complaints of urinary tract infection. The cause of these complaints might have been due to the urethral syndrome caused by organisms such as Chlamydia trachomatis ${ }^{12}$. No significant differences in side effects were observed between treatment regimens.

Major adverse effects -that is, enough to stop treatment- occurred only twice in the patients allocated to 7 days' treatment. These occurred less often than they did in other studies ${ }^{6,12}$.

Based on our results- that is, the similar symptomatic and bacteriological response 6 weeks after enrolment and the similar occurence of adverse effects in the 2 treatment groups in a study that included an adequate follow up period and a large enough sample to allow statistical analysis- we conclude that 3 days' treatment with co-trimoxazole is as effective as 7 days for the treatment of acute urinary tract infection in non-pregnant women. This study, however, was carried out in patients with more or less similar socioeconomic backgrounds and easy accessibility to well organised medical care. Whether these data could be generalized to other populations from lower socioeconomic backgrounds or with other forms of medical care remains to be elucidated.

We thank Drs G H M J Beusmans, W P M Vierhout, W H R Croughs, J R A Y van Rooy, L L J M Keysers, T F W A Krebbers, J Meyers, M Peeters, F W A Vissers, J A G Screever, A J M Screever-Delahaye, J J M Theunissen, F E G Verhaegh, A H Wintjens, P M Heyse, T S T van den Ven, J T Kramers, and $\mathrm{J} H \mathrm{M}$ Swinkels for their cooperation. The cotrimoxazole and placebos were supplied by Hoffmann La Roche. 


\section{REFERENCES}

1. Kunin CM. Detection, prevention and management of urinary tract infections. Lea and Febiger. 1987. $4^{\text {th }}$ edition.

2. Baselier P. Acute bacteriële urineweginfecties in de huisartspraktijk. PhD Thesis, University of Nijmegen, Nijmegen, The Netherlands. 1983.

3. Gleckman RA, Gantz NM, Brown RB. Infections in outpatient practice. Recognition and management. Plenum Medical Book Company, New York, London. 1988.

4. Gleckman RA. Treatment duration for urinary tract infections in adults. Minireview (1987). Antimicrob Agents Chemother 1987; 31, 1: $1-5$.

5. Greenberg RN, Reilly PM, Luppen KL, Weinandt WJ, Ellington LL, Bollinger MR. Randomized study of Single-dose, 3-days, and 7days treatment of cystitis in women. J Infect Dis 1986; 153, 2: 277282.

6. Tolkoff-Rubin NE, Weber D, Fang LST, Kelly M, Wilkinson R, Rubin RH. Single-dose therapy with trimethoprim sulfamethoxazole for urinary tract infection in women. Rev Infect Dis $1982 ; 4,2$ : 444448.

7. Counts GW, Stamm WE, McKevitt M, Running K, Holmes KK, Turck M. Treatment of cystitis in women with a single dose of trimethoprim-sulfamethoxazole. Rev Infect Dis 1982; 4, 2: 484-490.

8. Buckwold FJ, Ludwig P, Harding GKM, Thompson L, Slutchuk M, Shaw J, Ronald AR. Therapy for acute cystitis in adult women. JAMA 1982; 247: 1839-1842.

9. Philbrick JT, Bracikowski JP. Single dose antibiotic treatment for uncomplicated urinary tract infections. Arch Intern Med 1985; 145: $1672-1678$.

10. Freiman JA, Chalmers TC, Smith H, Kuebler RR. The importance of beta, the type II error and sample size in the design and interpretation of the randomized control trial. N Engl $J$ Med 1978; 299: 690694.

11. Fihn SD, Stamm WE. Interpretation and comparison of treatment studies for uncomplicated urinary tract infections in women. Rev Infect Dis 1985; 7: 468-478.

12. Fihn SD, Johnson C, Roberts PL, Running K, Stamm WE. Trimethoprim-sulfamethoxazole for acute dysuria in women: a single dose or 10-days course. Ann Intern Med 1988; 108: 350-357. 
13. Working Party of the British Society of Antimicrobial Chemotherapy. Clinical evaluation of antibacterial drugs. J Antimicrob Chemother 1989; 23, Suppl B.

14. Stobberingh EE, Houben AW. Antibioticaresistentie en antibioticagebruik wegens urineweginfecties in 11 Maastrichtse huisartsenpraktijken. Ned Tijd Geneesk 1988; 132, 39: 1793-1797.

15. McNutt LA, Woolson RF. Sample size for prospective and retrospective studies: the $2 \times 2$ table. Infect Control Hosp Epidemiol 1988; 9, 12 : $562-566$.

16. Pocock SJ. Clinical trials, a practical approach. Ed. John Wiley \& Sons, Chichester, U.K. 1987.

17. Shultz HJ, McCaffrey LA, Keys TF, Nobrega FT. Acute cystitis: a prospective study of laboratory tests and duration of therapy. Mayo Clin Proc 1984; 59: 391-397.

1.8. Gossius G, Vorland L. A randomized comparison of single dose vs. 3 days and 10 days therapy with trimpethoprim-sulfamethoxazole for acute cystitis in women. Scand JInfect Dis 1984; 16: 373-379.

19. Cramer JA, Mattson RH, Prevey ML, Scheyer RD, Quelette VL. How often is medication taken as prescribed? A novel assessment technique. JAMA $1989 ; 261: 3273-3277$.

20. Bailey RR, Blake E. Treatment of uncomplicated urinary tract infections with a single dose of cotrimoxazole. New Zeal Med J 1980; 92: 285-286.

21. Bailey RR, Abbott GD. Treatment of urinary tract infection with a single dose of trimethoprim-sulfamethoxazole. Canad Med Ass J 1978; 118: 551-552.

22. Gifford RH, Feinstein AR. A critique of methodology in studies of anticoagulant therapy for acute myocardial infarction. $N$ Engl $J$ Med 1969; 280: 351-357. 
CHAPTER IV

TREATING ACUTE URINARY INFECTIONS. AN RCT OF 3-DAY VERSUS 7-DAY NORFLOXACIN. 


\section{ABSTRACT}

A randomized double blind placebo controlled trial was carried out to compare two courses of treatment in women with complaints of acute urinary tract infection in general practice. The 3-day course of treatment was found to be as effective as, and cheaper than, the 7-day therapy for acute cystitis in general practice.

\section{INTRODUCTION}

Uncomplicated urinary tract infection (UTI) is a common disease in women, especially in general practice ${ }^{1,2}$. The length of treatment of uncomplicated UTI, i.e. 3 days versus 7 to 10 days has been a hot topic during the past 10 years $^{3-10}$.

Both treatment schedules have their benefits. Advantages of short-term treatment are better patient compliance, lower cost, and less frequent adverse effects $^{11}$. An advantage of long-term treatment is the reduced possibility of recurrent infections ${ }^{12}$. Although some studies promote 3-day treatment, most have not had a sufficient number of patients to support their

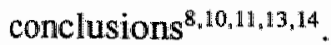

Recently, a new group of antimicrobial agents has been developed, of which norfloxacin is often prescribed for the treatment of UTI ${ }^{15,16}$. Many papers have been published on the clinical efficacy of different lengths of treatment with norfloxacin for $\mathrm{UTI}^{17-19}$. Although a 3-day course of trimethoprim-sulphamethoxazole is now accepted as adequate for the treatment of UTI, no extrapolations from one antibiotic to another should be made $^{8,20}$.

In this study, a 3-day course of norfloxacin was compared with a 7-day course of norfloxacin for the treatment of women visiting their family physicians in the southern part of The Netherlands with complaints of acute uncomplicated UTI. End points of evalution were the clinical and bacteriologic outcome, the number of adverse effects and cost.

\section{METHODS}

Included in the survey were women who were non-pregnant aged 18 to 65 years consulting their general practitioners with complaints of at least one of the following symptoms during the last 24 hours: dysuria, strangury, and frequent or urgent urination. Excluded from the survey were patients who had signs and symptoms of pyelonephritis, known abnormalities of the renal 
tract or diabetes. Also excluded were patients who had received either chemotherapy or antibiotics during the past month, patients who were known to be hypersensitive to nalidixic acid derivates and patients who had had a UTI within the last 3 months. General practitioners $(n=12)$ from the south of the Netherlands were asked to participate in this study.

The protocol was approved by the Medical Ethics Committee of Maastricht University Hospital. All patients received orall and written information and all gave informed consent. They were allocated to one or the other course of treatment in a double-blind, randomized way by means of the double dummy technique. The 2 strategies were: $400 \mathrm{mg}$ of norfloxacin twice daily for 7 days or $400 \mathrm{mg}$ of norfloxacin twice daily for 3 days followed by 4 days of placebo twice dailly.

A fresh urine sample was requested from all patients before the start of the medication, at the end of the medication ( 7 days later) and at least 6 weeks later. Patients were also asked to complete a questionnaire on compliance, relief of symptoms, and side effects. Patients were told to return to their general practitioners if symptoms did not disappear or if side effects occurred. Uropathogens were isolated and identified by standard microbiologic methods using API 20E (API Montalieu, Vercieu, France) for Enterobacteriaceae.

Cultures of $\geq 10^{5}$ colony forming units (cfu)/ml were considered to be positive. Cultures with 2 or more pathogens were regarded as mixed cultures. To evaluate patient compliance 1 week after starting medication, the presence of growth-inhibiting factors was tested. Clinical outcome was evaluated 1 and 6 weeks after starting medication through the questionnaire and data from the general practitioners. If patients returned to their physician with persistent complaints of UTI, the therapy was considered a failure.

Bacteriological outcome was scored as the elimination, persistence, or recurrence of the same or a different microorganism ${ }^{11}$. No distinction was made between relapse and reinfection because from the standpoint of the patient (and the physician), this distinction is unimportant ${ }^{8}$.

The short term cure rate was defined as the number of patients from whom the initial pathogen was eliminated compared with the number of evaluable patients. The accumulated cure rate was defined as the number of patients in whom cure was noted at the last control visit, compared with the number of evaluable patients ${ }^{14}$.

Adverse effects were also evaluated on the basis of the data of the questionnaire and information supplied by the physicians. If medication was stopped because of side-effects, the therapy was considered a failure.

Statistical significance was calculated by means of chi-square analysis. 
For an evaluation of the cost, it was assumed that a 3-day course was cheaper unless there was a statistically significant increase in the number of recurrences or a worse clinical outcome in this group. On the other hand, a shorter period of medication could be expected to produce fewer side effects in the 3-day treatment group. Therefore, the number of failures and the number of patients with additional visits to their general practitioners or to the urologist were compared in both groups.

Assuming a short term cure rate of $95 \%$ with 7 days of treatment, a type I error $(\alpha)$ of 0.05 , a type II error (B) of 0.20 , and a clinically important difference between treatments $(\delta)$ of $10 \%, 140$ patients in each group are required $8,11,13,21$.

The randomization was done by Merck Sharp \& Dohme (Haarlem, the Netherlands), which also supplied the medication. The code was not known to the investigators, the physicians or the patients. It was kept at the laboratory in a sealed envelope and was broken 6 weeks after the last patient was included.

\section{RESULTS}

From April 1989 to October 1990, 395 patients were randomized to 1 of the 2 groups. One hundred ninety-nine were allocated to the 3-day and 196 were allocated to the 7-day treatment. Eleven patients $(6$ in the short-term and 5 in the long-term group) did not return at all, so 384 patients (193 and 191 respectively) were evaluable. A bacteriologically positive urine sample was obtained from 144 and 141 patients, respectively. Escherichia coli was the most frequently isolated organism (104 and 111 respectively), followed by Staphylococcus spp. and Proteus spp. No differences between the 2 treatment groups were observed (table I).

Table I MICROORGANISMS ISOLATED IN TREATMENT GROUPS.

MICROORGANISMS

TREATMENT GROUP $(\%)^{*}$

3 DAYS

Escherichina coll

Proleus spp

Staphylococcus spp

other Enterobacteriaceae

Streptococcuss spp
7 DAYS

$111(79)$

$3(2)$

* Percentage of positive urine samples 
Patient compliance was recorded by using the answers provided by the patients on the questionnaire assessing the presence of growth-inhibiting factors in the urine 1 week after starting medication. The patients reported a $96 \%$ compliance; however, in only $76 \%$ of the urine samples of the 7 -day treatment group was the presence of a growth-inhibiting factor demonstrated.

For the clinical outcome 1 week after starting medication, 348 patients were evaluable, 175 in the short-term treatment group and 173 in the longterm treatment group. No significant differences in clinical outcome were observed between the groups (Table II). Twenty patients (10 in each group) still had complaints of dysuria; 15 of these $(7$ and 8 patients in the short-term and long-term groups, respectively) returned to their family doctors. Another antibiotic was prescribed to 4 out of the 7 in the first group and to 7 out of the 8 in the second group. Trimethoprim-sulphamethoxazole for 5 to 7 days was then the drug of choice. After the first week without any treatment, 3 patients in the 3-day treatment group and 8 in the 7-day group recovered. Some patients had symptoms only after the first week (but not at the first control visit).

Table II REILIEE OF SYMPTOMS 1 WEEK AND 6 WEEKS AFTER INITIATION.

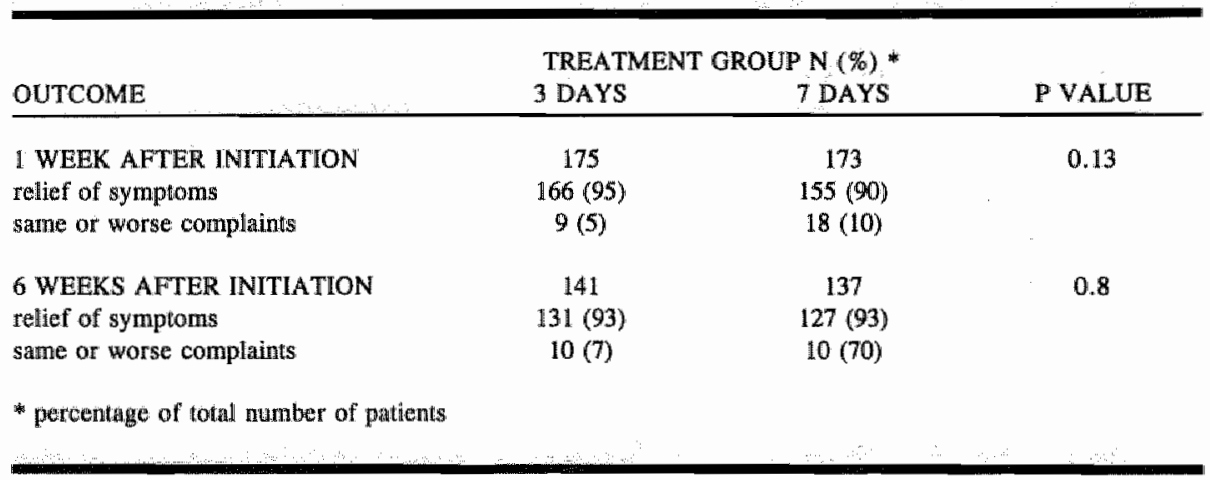

The bacteriological outcome was assessed as the short-term cure rate and the accumulated cure rate 1 week and 6 weeks after therapy, respectively. The short-term cure rates were $92 \%$ and $95 \%$ for the 3-day and 7 -day groups, respectively $(p=0.30)$. The accumulated cure rates were $82 \%$ for the 3-day group and 88\% for the 7-day group $(p=0.30)$ (table III). Adverse effects (gastrointestinal complaints, followed by headache and fatigue) occurred in $26(13 \%)$ and in $29(15 \%)$ patients respectively $(\mathrm{p}=0.79)$. 
Table II SHORT-TERM AND ACCUMULATED CURE RATES. ASSESSMENT 1 WEEK AND 6 WEEKS AFTER THERAPY.

\begin{tabular}{lcccccc}
\hline & \multicolumn{7}{c}{ TREATMENT GROUP } \\
TIME AFTER START OF THERAPY & 3 DAYS & 7 DAYS & 3 DAYS & 7 DAYS & \\
& TOTAL & N $(\%)$ & TOTAL & N (\%) & P VALUE \\
\hline one week & 169 & $155(92)$ & 169 & $161(95)$ & 0.30 \\
six weeks & 152 & $124(82)$ & 144 & $126(88)$ & 0.30 \\
& & & & & \\
\hline
\end{tabular}

The 3-day course of treatment was cheaper. Seven patients from the 3day and 8 patients from the 7-day group returned to their general practitioner. No difference was seen in the follow-up of these patients; most received an antimicrobial agent and none were sent to a hospital for further examination. Attention was also paid to the period of sick leave granted. No sick leave was recorded for women without a paid job. No significant differences were found between the 2 treatment groups. In total, 28 patients had a period of sick leave. The mean number of days of absence from work was 2.8 days in the 3 -day group 2.6 days in the 7-day group. The mean number of days of sick-leave per subject (patients without sick-leave included) was 0.4 days.

\section{DISCUSSION}

This study observed the recommendations made by Fihn and Stamm ${ }^{11}$ and the criteria suggested by the Working Party of the British Society of Antimicrobial Chemotherapy ${ }^{22}$. Even after 6 weeks, the number of patients with clinical symptoms of UTI and with a bacteriologically proven UTI was sufficient to avoid a type II error.

The difference between compliance levels reported by the patients on the questionnaires and those revealed by urinanalyses demonstrated that the patients" answers were not fully reliable. This was also mentioned by Urquhart and colleagues ${ }^{23}$, who tried to overcome this problem by developing a computerized pillbox to optimize the measurement of patient compliance.

Clinical outcome was considered the most important parameter for the patient. No difference in clinical failure rate was observed between the 2 treatment groups. Similar failure rates have been observed in other studies. Remarkably enough, when the patients ( 7 and 8 in the short-term and longterm groups respectively) returned to their general practitioner, a different medication was prescribed in 4 and 7 cases, respectively, irrespective of the 
presence of significant bacteriuria. A positive urine culture was present in only 2 and 5 patients, respectively.

In the economic evaluation no significant differences between both treatment regimens were observed, either in terms of return to the general practitioner or in terms of sick-leave. The only difference, then was the initial cost of the medication, which was, of course, lower in the shorter treatment course. It was significant that $76 \%$ of the patients in the 7 -day treatment group (using data on growth inhibiting factors in urine) complied. This means that $24 \%$ of the patients do not complete their therapy. It is not known wether they stopped after 1 day or after 5 days, but the fact that so many patients do not complete their antibacterial course suggests that general practitioners could be misled about the efficacy of 7-day treatment programs for UTI.

\section{CONCLUSIONS}

The results of this randomized, double-blind study conducted with a sufficient number of patients and adequate follow up, indicate a similar clinical and bacteriological cure rate 1 week and 6 weeks after the start of the medication, the same number of adverse effects, and lower costs for the 3day treatment. We can conclude from this that a 3-day course of norfloxacin is as effective as, and cheaper than, a 7-day course in the treatment of acute uncomplicated urinary tract infections in women who are not pregnant.

We thank the general practitioners GHMJ Beusmans, PhD, WHR Croughs, $H \vee$ Hapert, RAM de Jong, M Peeters, JRAY van Rooy, JAG Screever, AJM Screever-Delahaye, JJM Theunissen, FEG Verhaegh, WPM Vierhout and FWA Vissers for their cooperation in this study. 


\section{REFERENCES}

1. Baselier PJAM. Acute bacteriele urineweginfecties in de huisartspraktijk, PhD thesis, University of Nijmegen, Nijmegen. The Netherlands, 1983

2. Kunin $\mathbf{C M}$. Detection, prevention and management of urinary tract infections. Lea and Febiger, 1987. 4th edition

3. Bailey RR. Review of published studies on single dose therapy of urinary tract infection. Infection 1990; 18:53-56

4. Fihn SD, G Johnson, PL Poberts, K Running, WE Stamm. Trimethoprim-sulfamethoxazole for acute dysuria in women: a single dose or a 10 day course. Annals of Intern Med 1988; 108: 350-357

5. Gleckman RA. Treatment duration for urinary tract infections in adults. Antimicr Agents Chemother 1987; 31:1-5

6. Rylander M, SR Norrby, R Svard. Norfloxacin versus cotrimoxazole for treatment of urinary tract infections in adults: microbiological results of a coordinated study. Scand J Infect Dis 1987; 19:551-557

7. Nicolle LE. The optimal management of lower urinary tract infections. Infection 1990; 18:50-52

8. Norrby SR. Short-term treatment of uncomplicated urinary tract infections in women. Rev of Infect Dis 1990;12:458-467

9. Reeves DS, RW Lacey, RV Mummery, M Mahendra, AJ Bint, SWB Newson. Treatment of acute urinary infection by norfloxacin or nalidixic acid/citrate: a multicentre comparative study. J Antimicrob Chemother 1984; 13:99-105.

10. Philbrick JT, JP Bracikovski. Single dose antibiotic treatment for uncomplicated urinary tract infections. Less for less? Arch Intern Med $1985 ; 145: 1672-1678$.

11. Fihn SD, WE Stamm. Interpretation and comparison of treatment studies for uncomplicated urinary tract infections in women. Rev of Infect Dis $1985 ; 7: 468-478$.

12. The Internordic Urinary Tract Infection Study Group. Double-blind comparison of 3-day versus 7-day treatment with norfloxacin in symptomatic urinary tract infections. Scand J Infect Dis 1988; 20:619-624.

13. Nederlands Huisartsen Genootschap. Standaard urineweginfecties. Huisarts en Wetenschap 1989; 32:527-530.

14. Huitfeldt B. Statistical aspects of clinical trials of antibiotics in acute infections. Rev Infect Dis 1986; 8:suppl.B 350-357. 
15. Norrby SR Treatment of urinary tract infections with quinolone antimicrobial agents, in Wolfson \& Hooper. Quinolone antimicrobial agents. Ist edition.

16. Wolfson JS, BE Murray. Value of new quinolones in the treatment and prophylaxis of infectious diseases: introductory remarks Eur J Clin Microbiol Infect Dis 1989:8:1071-1074.

17. Goldstein EJC, ML Albert, BP Ginsberg. Norfloxacin ws. trimethoprim-sulfamethoxazole in the therapy of uncomplicated, community-acquired urinary tract infections. Antimicrob Agents Chemother 1985;27:422-423.

18. Sabbaj J, VL Hoagland, WJ Shih. Multiclinic comparative study of norfloxacin and trimethoprim-sulfamethoxazole for urinary tract infections. Antimicr Agents Chemother 1985;27:297-301.

19. Urinary Tract Infection Study Group. Coordinated multicenter study of norfloxacin versus trimethoprim-sulfamethoxazole treatment of symptomatic urinary tract infections. J Infect Dis 1987; 155:170-177.

20. Trienekens TAM, EE Stobberingh, RAG Winkens, AW Houben. Different lengths of treatment with co-trimoxazole for acute uncomplicated urinary tract infections in women. $\mathrm{Br}$ Med $\mathrm{J} 1989$; 299:1319-1322.

21. Pocock SJ. Clinical trials, a practical approach. Chichester; John Wiley, 1987.

22. Working Party of the British Society of Antimicrobial Chemotherapy. Clinical evaluation of antimicrobial drugs. J Antimicrob Chemother 1989; 23(suppl B):1-39.

23. Urquhart J, J Bell, JM Metry. Meta-analysis of reported studies with micro-electronic monitoring of patient compliance. J Clin Res Drug Dev $1989 ; 3: 227$. 
CHAPTER V

AEROBACTIN AND OTHER VIRULENCE ASSOCIATED FACTORS OF ESCHERICHIA COLI AND INFLUENCE OF SUBMINIMAL CONCENTRATIONS OF FLUOROQUINOLONES. 
62 


\section{SUMMARY}

In the present study the influence of subinhibitory concentrations of three quinolones (norfloxacin, ofloxacin and ciprofloxacin) on virulence associated factors in Escherichia coli isolated from asymptomatic bacteriuria $(\mathrm{n}=70)$ and cystitis strains $(\mathrm{n}=45)$ was described. The virulence associated factors studied were presence of the aerobactin genes, serotype, hemagglutination and the production of hemolysin. No significant differences between the 2 groups of strains with respect to the virulence factors were observed.

A different approach to study the influence of the quinolones on the aerobactin genes was made: aerobactin encoded RNA was detected with a specific DNA probe.

No influence of subminimal concentrations of the 3 quinolones on the aerobactin encoded RNA was observed either on the hemagglutination or on the hemolysin production.

\section{INTRODUCTION}

Escherichia coli have to produce one or more virulence factors (VF) to overcome the normal host-defences and to cause disease in hosts ${ }^{1}$. In the past VFs studied were adherence ${ }^{2}$, fimbriae ${ }^{3}$, hemolysin ${ }^{4}$ and $\mathrm{O}$ and $\mathrm{K}$ serology ${ }^{5,6}$. In the last few years renewed interest has been shown to another virulence factor, the production of aerobactin?. Aerobactin is a specific bacterial siderophore, which extracts iron from the environment. Iron is needed by all living cells ${ }^{8}$ and is therefore a very important factor for the survival of bacteria in the host, including the urinary tract. Sublethal concentrations of antibiotics produced a reduction in siderophore production $^{9,10,11}$. However, the influence of these concentrations on the aerobactin production have not been studied quite extensively.

Aerobactin can be quantified by the so-called Csàky method ${ }^{12}$, which is labourious and in which toxic chemicals are used ${ }^{13}$. A bioassay has also been described, but this method is susceptible to trivial variations in bacterial physiology ${ }^{13}$. Because up till now little is known about the mechanism of the influence of quinolones on the aerobactin production, a specific aerobactin probe $^{13}$ was used to detect aerobactin expressing RNA. Two groups of uropathogenic Escherichia coli were studied: i.e. strains isolated from pregnant women with asymptomatic bacteriuria $(A B U)$ and strains from nonpregnant women with an acute cystitis (CYS). Also the prevalence of 3 other 
VF e.g. serology (SER), hemagglutination (HA) and hemolysin production (HLY) were studied, as well as the influence of 3 quinolones on the last 2 VF.

\section{MATERIALS AND METHODS}

\section{BACTERIA}

Escherichia coli strains isolated from patients with CYS and from pregnant women with ABU were studied. CYS strains $(n=45)$ were defined as follows: bacteria isolated from the urine in a number of $\geq 10^{5} \mathrm{cfu} / \mathrm{ml}$ of non-pregnant women, presenting with complaints of dysuria, stranguria, urinary frequency or urgency in the past 24 hours. ABU strains $(n=70)$ were isolated from pregnant women, who visited the antenatal clinic of the University Hospital in Maastricht for a routine screening at a gestational age between 8 and 13 weeks. If $\geq 10^{5} \mathrm{cfu} / \mathrm{ml}$ were present in 2 consecutive urine samples the strains were included in the present study.

\section{HEMAGGLUTINATION ASSAY}

The hemagglutination assay was performed in microtiter plates as previously described ${ }^{14}$. The titers were expressed as the highest dilutions of bacteria showing hemagglutination. Strains were tested for MSHA (mannose sensitive hemagglutination i.e.type I fimbriae) and MRHA (mannose resistant hemagglutination) with guinea pig and human erythrocytes respectively in the presence and absence of mannose. The presence of $P$ fimbriae in MRHA strains was determined by performing a commercially available latex agglutination test (Orion Diagnostica, Finland). MRHA strains not agglutinating were considered to have $\mathrm{X}$ fimbriae.

\section{SEROTYPING OF ESCHERICHA COLI}

The somatic $(\mathrm{O})$ and capsular $(\mathrm{K})$ antigens were determined using an agglutination assay at the National Institute, for Public Health and Environmental Hygiene, Bilthoven, the Netherlands.

\section{HEMOLYSIN PRODUCTION}

Hemolysin production was assessed qualitatively in nutrient agar (Oxoid CM3) with $5 \%$ sheep erythrocytes. A haemolytic zone larger than the overlying colony was considered as positive.

\section{PURIFICATION OF AEROBACTIN PROBE AND RNA ISOLATION}

Plasmid DNA was isolated by the method of Sambrook ${ }^{15}$. The aerobactin probe consisted of a $2.2 \mathrm{~kb}$ Aval fragment of $\mathrm{pABN5} 5^{13}$ encoding a part of the biosynthesis genes. (The probe was kindly provided by 
K.G.Wooldridge). The probe as labeled with digoxigenine according to the manufacturer's instructions (Boeringer Mannheim, Mannheim, Germany).

RNA was isolated by the guanidine-thyocyanate method (15). In short, bacteria were lyzed with lysozyme $(2.5 \mathrm{mg} / \mathrm{ml})$ and the RNA was extracted with a solution containing guanidine-thyocyanate $(4 \mathrm{M})$, sodium citrate $(20 \mathrm{mM}), B$-mercapto-ethanol $(0.5 \%)$ and sarcosyl $(0.5 \%)$, purified with fenol-chloroform (49:1) extractions and precipitated with pure ethanol. RNA was then transferred to nylon membranes (Nytran. Schleicher \& Schuell, Den Bosch, The Netherlands).

Prehybridization and hybridization were done under stringent conditions at $42^{\circ} \mathrm{C}$ in formamide $50 \%, 5 * \operatorname{SSC}$, sarcosyl $0.1 \%$, SDS $0.02 \%$, salmon sperm $0.5 \%$ and blocking reagent (Dig kit, Boehringer Mannheim, Mannheim, Germany) with washes in $2 * S S C$ and $0.1 \%$ SDS at $68^{\circ} \mathrm{C}$.

Detection of digoxigenine labeled nucleic acids was performed by chemoluminescence on radiographic films (Kodak X Omat AR).

ANTIMICROBIAL AGENTS

The antibiotics used were norfloxacin, (Merck, Sharp and Dohme, Rahway, New Yersey, USA) ofloxacin, (Hoechst AG Frankfurt, Germany) and ciprofloxacin (Bayer AG Leverkusen, Germany). The compounds were kindly provided by their respective manufacturers.

\section{INFLUENCE OF ANTIBIOTICS ON VIRULENCE ASSOCIATED PROPERTIES.}

To study the effect of subinhibitory concentrations ( $1 / 2$ and $1 / 4 \mathrm{MIC}$ ) of the quinolones on $\mathrm{HA}$ activity an overnight culture of the microorganisms was washed and diluted to a concentration of $10^{5} \mathrm{cfu} / \mathrm{ml}$ in fresh broth. After 2 hours of incubation at $37^{\circ} \mathrm{C}$ with shaking the antibiotic was added and the culture was further incubated for 2 hours. Then the bacteria were washed to remove the drug and were adjusted to the concentration of bacteria needed. Subsequently the hemagglutination assay was performed as described above. The influence of the quinolones on the hemolysin production was assessed in blood agar plates containing $1 / 2$ and $1 / 4$ MIC of the antimicrobials studied.

To study the influence of the quinolones on the expression of the aerobactin production, $3 \mathrm{P}$ fimbriated CYS and $3 \mathrm{P}$ fimbriated ABU strains were randomly selected. The microorganisms were cultured overnight in the presence of $1 / 2$ and $1 / 4$ MIC of the quinolones in iron deficient minimal medium containing $25 \mathrm{mM} 2,2$ 'dipyridyl (Sigma). Subsequently the RNA isolation was performed as described before.

STATISTICS

Differences in prevalence of VF between the 2 groups were compared by chi-square test. $\mathrm{P}<0.05$ was considered to be significant. 


\section{RESULTS}

According to the HA pattern, the Escherichia coll strains could be classified as $\mathrm{P}$, type $\mathrm{I}, \mathrm{X}$ or non-haemagglutinating (Table I). The prevalence of type I strains was quite similar among CYS and ABU isolates (i.e. $57 \%$ in both groups). In the CYS group more $P, X$ and non-HA strains were observed compared to the $\mathrm{ABU}$ group, but the differences were not significant (ns). The mean $\mathrm{HA}$ titer of the strains with $\mathrm{P}$ adhesins was $1: 16$ and 1:32 for the CYS and for the ABU group respectively. (Titers are not shown). The mean HA titer of the type I fimbriated strains (1:16 or 1:32) was quite simillar for both $\mathrm{ABU}$ and CYS strains. For the P fimbriated strains the HA titer in both the CYS and ABU strains $(1: 8$ or $1: 16)$ tended to be lower than in the $\mathrm{X}$ fimbriated strains $(1: 16$ or $1: 128)$.

Table I VIRULENCE PROPERTIES OF ESCHERICHLA COLI.

VIRULENCE FACTORS

ESCHERICHIA COLI

ABU $N=70(\%) \quad$ CYS $N=44(\%) \quad$ P VALUE

\begin{tabular}{|c|c|c|c|c|c|c|}
\hline \multirow[t]{4}{*}{ HEMAGGLUTINATION } & $\begin{array}{l}\text { mannose sensitive } \\
\text { (type I) }\end{array}$ & 40 & $(57)$ & 26 & (59) & NS \\
\hline & $\begin{array}{l}\text { mannose resistant } \\
\text { ( } \mathrm{P} \text { firnbriae) }\end{array}$ & 8 & $(11)$ & 7 & $(16)$ & NS \\
\hline & $\begin{array}{l}\text { mannose resistant } \\
\text { (X fimbriae) }\end{array}$ & 1 & (1) & 4 & (9) & NS \\
\hline & $\begin{array}{l}\text { no } \\
\text { hernagglutination }\end{array}$ & 21 & $(30)$ & 7 & (16) & NS \\
\hline \multicolumn{2}{|c|}{ HEMOLYSIN PRODUCTION } & 14 & $(20)$ & 13 & $(30)$ & NS \\
\hline \multicolumn{2}{|c|}{ SEROLOOY $(02,4,6,7,8,16,18,25,75)$} & 23 & (33) & 24 & (53) & $P<0.05$ \\
\hline \multicolumn{2}{|c|}{ AEROBACTIN PRODUCTION } & 25 & $(36)$ & 20 & (45) & NS \\
\hline
\end{tabular}

The uropathogenic associated $O$ serotypes $(01,2,4,6,8,9,25$, and 75) occurred slightly more in the CYS than in the ABU group (Table I) The $\mathrm{O} 2$ serotype was the most prevalent type among CYS strains (20\%), 4 strains belonged to the $02 \mathrm{~K} 1$ serotype. The $\mathrm{O} 6$ type was found in 7 out of $70(10 \%)$ ABU strains. 
Also the differences in Hly production of ABU strains and CYS strains were not statistically different (19\% and $29 \%$ respectively) (Table I).

AER positive strains were found among ABU and CYS strains with a prevalence of $36 \%$ and $45 \%$ respectively. Although more AER positive strains belonged to the CYS group, the difference was not statistically significant $(\mathrm{p}>0.05)$ (Table I)

\section{INFLUENCE OF FLUOROQUINOLONES ON VIRULENCE ASSOCIATED FACTORS}

The HA titer was not affected by the presence of $1 / 2$ or $1 / 4 \mathrm{MIC}$ of the three quinolones studied. In contrast, subMIC of the compounds used did influence the HLY production. Two CYS and 3 ABU strains, which showed no HLY production in the absence of the quinolones, did so in the presence of each of the 3 agents. In addition, 1 CYS and 4 ABU strains became HLY positive but only in the presence of norfloxacin. Culturing of the $A B U(n=3)$ and CYS $(n=3)$ strains in the absence or the presence of $1 / 2$ or $1 / 4 \mathrm{MIC}$ of the quinolones studied did not influence the amount of RNA encoding for the expression of aerobactin. (Figure I)

Figure I AEROBACTIN ENCODED RNA INCUBATED WITH AND WITHOUT SUBINHIBITORY CONCENTRATIONS (1/2 AND 1/4 MIC) OF THREE QUINOLONES: NORFLOXACIN (NOR), OFLOXACIN (OFLO), AND CIPROFLOXACIN (CIP) DETECTED WITH A DIGOXIGENIN LABELED DNA PROBE. A POSITIVE $(+)$ (pABN5) AND NEGATIVE $(\rightarrow$ (HBIO1) CONTROL STRAIN WERE INCLUDED IN THE ANALYSIS.

\begin{tabular}{|c|c|c|c|c|c|c|}
\hline & $\mathrm{P} 40$ & P89 & P116 & P331 & P577 & P714 \\
\hline $1 / 2 \mathrm{MIC}$ NOR & ++ & ++ & ++ & ++ & ++ & ++ \\
\hline 1/2 MIC OFLO & ++ & $4+$ & ++ & $+t$ & ++ & $+t$ \\
\hline $1 / 2 \mathrm{MIC} \mathrm{CIP}$ & ++ & ++ & +4 & ++ & $+t$ & ++ \\
\hline 1/4 MIC NOR & $+t$ & +4 & $t+$ & $4+$ & ++ & $t+4$ \\
\hline I/4 MIC OFLO & $t+$ & $+t$ & ++ & $+t$ & ++ & ++ \\
\hline $1 / 4$ MIC CIP & $+t$ & $t+$ & +4 & ++ & ++ & $+t$ \\
\hline WITHOUT & ++ & ++ & ++ & ++ & +4 & ++ \\
\hline CONTROL & $\begin{array}{l}++ \\
\text { POS }\end{array}$ & NEG & $\begin{array}{l}+4 \\
\text { pos }\end{array}$ & NEG & $\begin{array}{l}++ \\
\text { POS }\end{array}$ & NEG \\
\hline
\end{tabular}




\section{DISCUSSION}

In the present study the prevalence of virulence associated factors studied among CYS strains were lower than those mentioned by other investigators. MRHA were present among $35 \%$ and $31 \%$ of the strains studied by Hagberg ${ }^{16}$ and Sandberg ${ }^{17}$ respectively; Dalet ${ }^{18}$ and Stenqvist ${ }^{19}$ mentioned $20 \%$ and $19 \%$ respectively, compared to $14 \%$ in this study. Hemolysin production was observed in $48 \%$ and $49 \%$ of the stains studied by Orskov $^{20}$ and Sandberg ${ }^{17}$ respectively. In the present study $29 \%$ was found. Also the prevalence of aerobactin producing strains was in the studies of Orskov $^{20}$ and Carbonetti ${ }^{21}$ slightly higher than in the present study i.e. $56 \%$, $60 \%$ and $45 \%$ respectively.

It is not very likely that the differences in prevalence observed might be due to differences in methods used. All studies mentioned above including the present one used the same methods for aerobactin production, MRHA, as well as hemolysin production. The variations in data observed might be due to differences in populations studied. In the present paper only outpatient women with complaints of cystitis were studied. Sandberg ${ }^{17}$ included patients who were referred to a hospital, Orskov ${ }^{20}$, Carbonetti ${ }^{21}$ and Hagberg ${ }^{16}$ included children in the population studied. Dalet ${ }^{18}$ and Stenqvist ${ }^{19}$ included acute uncomplicated cystitis strains of adults and pregnant women respectively. The last two studies were similar to the present one, not only in terms of the populations studied, but also in terms of the percentages observed. The data suggest that strains from hospitalized patients and from children are more virulent than from outpatient women. Jacobson ${ }^{22}$ already described that pyelonephritogenic strains from children were more virulent than the pyelonephritogenic strains from adults. He also found a difference between cystitis strains from children and adults ${ }^{23}$. Therefore it might be possible that differences between lower UTI strains isolated from children and from adults do exists.

Similar to the study of Kovarik et all. ${ }^{24}$ in the present study no effect of subMIC quinolones on the hemagglutination titer was observed. In both studies a correction was made for the number of bacteria used. The effect on the hemagglutination titer found in other studies might be due to a reduction in the number of bacteria used in the HA assay. Most investigators did not correct for the number of bacteria ${ }^{25,26,27}$.

Although there was a tendency that subMIC norfloxacin might increase the hemolysin production, there was in general no significant influence of norfloxacin, ofloxacin and ciprofloxacin on the hemagglutination, the hemolysin and the expression of the aerobactin genes noticeable. 
In the present study no influence of each of the 3 quinolones on the expression of aerobactin encoded RNA in Escherichia coli was found. Similar data were obtained by Morris ${ }^{11}$ with ciprofloxacin and Pseudomonas aeruginosa. However, in the same study the use of subMIC of aminoglycosides did reduce the aerobactin production. Similar results were obtained by Courcol ${ }^{9}$ in Staphylococccus aureus.

In this study the aerobactin genes and amount of aerobactin encoded RNA was detected with a specific DNA probe instead of using a bioassay (28). A disadvantage of the bioassay is that it does not always work satisfactorily (29). A pitfall might be that many strains could produce colicins - other than aerobactin - to which the test strain is susceptible (instead of aerobactin-resistant). A positive bioassay might be overlooked in these circumstances. An advantage of gene detection is that insight in molecular processes can be obtained. The amounts of aerobactin encoded RNA (and thus the amount of the aerobactin molecule itself produced) can be compared. A comparison between strains incubated with and without quinolones can be made. However, the influence of the quinolones on the amount of aerobactinencoded RNA detected was not different between the strains incubated with and without quinolones. 


\section{REFERENCES}

1. Johnson J.R., Virulence factors in Escherichia coli urinary tract infections. Clinical Microbiological Reviews 1991, 4, 80-128.

2. Beachey E.H., Bacterial adherence: adhesin receptor interactions mediating the attachment of bacteria to mucosal surfaces. The Journal of Infectious Diseases 1981, 143, 325-345.

3. Krogfelt K.A., Bacterial adhesion: genetics, biogenesis, and role in pathogenesis of fimbrial adhesins of Escherichia coli. Reviews of Infectious Diseases 1991, 13, 721-735.

4. Smith H.W., The haemolysins of Escherichia coli. Journal of Pathology and Bacteriology 1973, 85, 197-211.

5. Kaijser B., Immunology of Escherichia coli: $\mathrm{K}$ antigen and its relation to urinary tract infection. Journal of Infectious Diseases 1973, $127,670-677$.

6. Green C.P. and V.L.Thomas, Hemagglutination of human type O erythrocytes, hemolysin production, and serogrouping of Escherichia coli isolates from patients with acute pyelonephritis, cystitis, and asymptomatic bacteriuria. Infection and Immunity, 1981, 31, 309-315.

7. de Lorenzo V. and J.L.Martinez, Aerobactin production as a virulence factor: a reevaluation. European Journal of Clinical Microbiollogy and Infectious Diseases 1988, 7, 621-629.

8. Herschko C., T.E.A.Peto and D.J. Weatherall, Iron and infection. British Medical Journal 1988, 296, 660-664.

9. Courcol R.J., P.A.Lambert, P.Fournier, G.R.Martin and M.R.W.Brown. Effects of iron depletion and sub-inhibitory concentrations of antibiotics on siderophore production by Staphylococcus aureus. Journal of Antimicrobial Chenotherapy 1991, 28, 663-668.

10. Kadurugamuwa J.L., H.Anwar, M.R.W.Brown and O.Zak. Effects of subinhibitory concentrations of cephalosporins on surface properties and siderophore production in iron-depleted Klebsiella pneumoniae. Antimicrobial Agents and Chemotherapy 1985, 27, 220223.

11. Morris G. and M.R.W.Brown. Novel modes of action of aminoglycoside antibiotics against Pseudomonas aeruginosa. The Lancet 1988, 1359-1361.

12. Csáky T.Z. On the estimation of bound hydroxylamine in biological methods. Acta Chemica Scandinavica 1948, 2, 450-454. 
13. Williams P.H. DNA probes for Escherichia coli isolates from human extraintestinal infections. In: A.J.L. Macario, E. Conway de Macario (ed): Gene probes for bacteria. Academic Press.Inc San Diego California, 1990, p. 143-165.

14. Duguid J.P., S.Clegg and M.I.Wilson. The fimbrial and nonfimbrial haemagglutinins of Escherichia coli. Journal of Medical Microbiology 1979, 12, 213-227.

15. Sambrook J., E.F.Fritsch, and T.Maniatis. Molecular cloning: a laboratory manual. 2nd ed. Cold Spring Harbor Laboratory, Cold Spring Harbor, New York, 1989.

16. Hagberg L., U.Jodal, T.K.Korhonen, G.Lidin-Janson, U.Lindberg, C.Svanborg-Eden. Adhesion, hemagglutination, and virulence of Escherichia coli causing urinary tract infections. Infection and Immunity 1981, 31, 564-570.

17. Sandberg T., B.Kayser, G.Lidin-Janson, K.Lincoln, F.Orskov I.Orskov et al. Virulence of Escherichia coli in relation to host factors in women with symptomatic urinary tract infection. Journal of Clinical Microbiology 1988, 26,1471-1476.

18. Dalet F., T.Segovia, G. Del Rio. Frequency and distribution of uropathogenic Escherichia coli adhesins: a clinical correlation over 2,000 cases. European Urology, 1991, 19, 295-303.

19. Stenquist K., T.Sandberg, G.Lidin-Janson, F.Orskov, I.Orskov, C.Svanborg-Eden. Virulence factors of Escherichia coli in urinary isolates from pregnant women. Journal of Infectious Diseases, 1987, $156,870-877$.

20. Orskov I., C.Svanborg-Eden, F.Orskov. Aerobactin production of serotyped Escherichia coli from urinary tract infection. Medical Microbiology and Immunology, 1988, 177, 9-14.

21. Carbonetti N.H., S.Boonchai, S.H.Parry, V.Väisänen-Rhen, T.K.Korhonen, P.H.Williams. Aerobactin-mediated iron uptake by Escherichia coli isolates from human extraintestinal infections. Infection and Immunity 1986, 51, 966-968.

22. Jacobson S.H., M.Katouli, K.Tullus, A.Brauner. Phenotypic differences and characteristics of pyelonephritogenic strains of Escherichia coli isolated from children and adults. Journal of Infection, 1990, 21, 279-286.

23. Jacobson S.H., H.Hammalind, K.J.Lidefeldt, E.Osterberg, K.Tullus, A.Brauner. Incidence of aerobactin-positive Escherichia coli strains in patients with symptomatic urinary tract infections. 
European Journal of Clinical Microbiology and infectious Diseases $1988,7,630-634$.

24. Kovarik J.M., I.M.Hoepelman and J.Verhoef, Influence of fluoroquinolones on expression and function of $\mathbf{P}$ fimbriae in uropathogenic Escherichia coli. Antimicrobial Agents and Chemotherapy, 1989, 33, 684-688.

25. Hales B., and S.G.B.Amyes (1985). The effect of a range of antimicrobial drugs on the haemagglutination of two clinicall isolates from urinary tract infection. Journal of Antimicrobial Chemotherapy. 16,671-674.

26. Väisänen V., K.Louhatmaa, T.K.Korhonen (1982). Effect of sublethal concentrations of antimicrobial agent on the haemagglutination, adherence and ultrastructure of pyelonephritogenic Escherichia coli strains. Antimicrobial Agents and Chemotherapy: 22, 120-127.

27. Vosbeck K., H.Mett, U.Huber, J.Bohn, M.Petignan (1982). Effects of low concentrations of antibiotics on Escherichia coli adhesion. Antimicrobial Agents Chemotherapy. 21,64-869.

28. Carbonetti N.H. and P.H.Williams. Detection of synthesis of the hydroxamate siderophore aerobactin by pathogenic isolates of Escherichia coli. In: The virulence of Escherichia coli, M.Sussman (ed) Academic Press Inc. London LTD, 1985, p.419-424

29. Orskov I., P.H.Williams, C.Svanborg-Edén, F.Orskov. Assessment of biological and colony hybridization assays for detection of the aerobactin system in Escherichia coli from urinary tract infections. Microbiology and Immunology, 1989, 143-148. 
CHAPTER VI

INFLUENCE OF QUINOLONES ON THE ADHERENCE AND PRODUCTION OF P FIMBRIAE OF ESCHERICHIA COLI 
74 


\section{SUMMARY}

The influence of subinhibitory concentrations of norfloxacin on the production and expression of P fimbriae of uropathogenic Escherichia coli.

The effect of a range of subminimal concentrations of norfloxacin (1/2 to $1 / 32 \mathrm{MIC}$ ) on $\mathrm{P}$ fimbriae production and on expression of $\mathbb{P}$ fimbrial RNA was measured with an inhibition ELISA using monoclonal antibodies against the different serotypes of $P$ fimbriae and a $P$ fimbrial DNA probe respectively. Trimethoprim in the same subinhibitory concentrations was used as the control agent. Electron microscopy was used to visualize the presence and the amount of $\mathrm{P}$ fimbriae.

Norfloxacin resulted in the ELISA as well as the RNA assay in a decrease of $P$ fimbrial production and expression. Electron microscopy revealed no significant decrease in amount of $\mathrm{P}$ fimbriae of the strains tested in the presence trimethoprim or norfloxacin.

Moreover adhesion of Escherichia coli strains $(\mathrm{n}=6)$ to a T24 uroma celline after exposure to norfloxacin, ofloxacin and ciprofloxacin was tested. Adhesion diminished significantly in five out of six strains in the presence of $1 / 2$ MIC of norfloxacin. Exposure to ofloxacin resulted in a decrease in 1 and in an increase in 2 strains, ciprofloxacin only resulted in a decrease in 1 strain.

In conclusion, rather no influence of ciprofloxacin and ofloxacin on adhesion of Escherichia coli to a T24 celline was observed, whereas norfloxacin showed a decrease in adhesion (adherence assay) and in adhesive capacity (ELISA assay and DNA probe) but not in the number of fimbriae (EM). These data suggest, that not the total fimbriae production, but rather the adhesive structure itself is affected by subinhibitory concentrations of norfloxacin.

\section{INTRODUCTION}

P fimbriae are the most important group of fimbriae of uropathogenic Escherichia coli involved in the pathogenesis of urinary tract infections (UTI) ${ }^{1,10,14,17}$. The role of these fimbriae in bacterial adherence to uroepithelial cells as well as in facilitating bacterial colonization and invasion into uroepithelial cells is widely accepted now $w^{6,10,11,12,26}$. However, bacterial adherence can be inhibited by subinhibitory concentrations (subMICs) of some antimicrobial agents and thus prevent bacterial colonization and infections ${ }^{2}$. 
Most studies on the effect of subMICs on bacterial adhesion have been performed with uropathogenic Escherichia coll, human urinary bladder epithelial cells and antimicrobial agents used for the treatment of UTI. In general a decreased adherence in the presence of subMiCs was observed although the reversed was found as well ${ }^{13,20,22,23,27,28,30}$. As to the mechanism of the altered adherence mediated by subMICs, only trimethoprim is known to alter fimbrial production ${ }^{4}$.

Recently, a new group of antimicrobial agents i.e. the fluoroquinolones has been introduced, which can be used for the treatment of UTI ${ }^{7,29}$. Only few data on the effect of subMiCs of these agents on the bacterial adherence of uropathogenic Escherichia coli are available ${ }^{13}$.

In this study, the influence of subMICs of norfloxacin $(1 / 2$ to $1 / 32)$ on the adherence of 14 clinical isolates of Escherichia coli to T24 human urinary bladder celline was assessed using $P$ fimbrial monoclonal antibodies. In addition the effect on the $\mathrm{P}$ fimbrial production and expression was assessed. Moreover, the effect of subMICs of ciprofloxacin, norfloxacin and ciprofloxacin on the adherence of six of these fourteen strains to the T24 celline were assessed by light microscopy.

\section{MATERIALS AND METHODS}

\section{BACTERIAL STRAINS}

Escherichia coli strains were isolated from patients suffering from cystitis (CYS) $(n=7)$ or from pregnant women with an asymptomatic bacteriuria $(A B U)(n=7)$. Strains were isolated if $\geq 10^{5}$ collony forming units $(\mathrm{cfu}) / \mathrm{ml}$ were present in 1 or 2 consecutive urine samples respectively. Bacteria were isolated and identified as Escherichia coli using standard microbiological methods including API20E (APIlab, Monterieux, France). The presence of $\mathrm{P}$ fimbriae was determined using a commercially available latex agglutination test according to the manufacturers instructions (PF test, Orion Diagnostica, Finland). Strains were cultured on colonization factor antigen (CFA) agar to promote $\mathrm{P}$ fimbriae expression.

Seven ABU and 7 CYS strains and 4 reference $P$ fimbriated strains were used in the ELISA assay. Six of these strains ( $3 \mathrm{ABU}$ and 3 CYS) were also used in the adherence and probe assay (table I).

\section{ANTIMICROBIAL AGENTS}

The antibiotics used were kindly provided by their respective manufacturers. The minimum inhibitory concentration (MIC) was determined using a microbroth dilution method in $\mathbb{I S O}$ sensitest broth (Oxoid CM 473). Serial twofold dilutions of the antibiotic in ISO sensitest broth were 
inoculated with $10^{5} \mathrm{cfu} / \mathrm{ml}$ bacteria and incubated without shaking at $37^{\circ} \mathrm{C}$ for $18 \mathrm{hr}$. The lowest concentration of antibiotic agent that inhibited visible growth was detined as the MIC.

Table I ESCHERICHLA COLI STRAINS USED IN THIS STUDY.

\begin{tabular}{|c|c|c|c|c|}
\hline STRAIN & REFERENCE & FIMBRIAE & SOURCE & $\begin{array}{l}\text { MONOCLONAL } \\
\text { ANTIBODIES }\end{array}$ \\
\hline C 1018 & J M de Ree & F9: & pyelonephritis & $M 4-7$ \\
\hline C1976 & & F11 & pyelonephritis & $M 7.7$ \\
\hline $\mathrm{C} 1979$ & & F12 & pyelonephritis & M14-5 \\
\hline $\mathrm{C} 1212$ & & $\mathrm{~F} 7_{1}, \mathrm{FT}_{2}$ & pyelonephritis & $M 6-3, M 7-5, M 2-11$ \\
\hline $\mathbb{H B 1 0 1}$ & & none & & \\
\hline P40* & & F11 & asymptomatic bacteriuria & $M 7-7$ \\
\hline P89 & & - & asymptomatic bacteriuria & $\cdots$ \\
\hline P116* & & F8 & asymptomatic bacteriuria & M17-9S \\
\hline 134 & & F8 & asymptomatic bacteriuria & Mil-9S \\
\hline 3030 & & F11 & asymptomatic bacteriuria & $\mathrm{M} 7-7$ \\
\hline 24 & & FII & assymptomatic bacteriuria & $M 7-7$ \\
\hline 53 & & $\mathbb{F}]_{2}$ & asymptomatic bacteriuria & M2-11 \\
\hline 134 & & $\mathrm{Fs}$ & asymptomatic bacteriuria & M17.9S \\
\hline $\mathrm{P} 714 *$ & & $-\quad \because \because$ & cystitis & $m$ \\
\hline $\mathrm{P} 331 *$ & & Fil & cystitus & M7-7 \\
\hline P577 & & {[]$_{1}$} & cystitis & M6-3 \\
\hline 493 & & $F 8$ & cystitis & M17-95 \\
\hline 441 & & F11 & cystitis & $M 7.7$ \\
\hline 605 & & $\mathrm{Fg}$ & cystitis & $M 4-7$ \\
\hline 600 & & - & cystitis & $-\sim$ \\
\hline
\end{tabular}

\section{ANTIBIOTIC TREATMENT}

To study the effect of subinhibitory concentrations ( $1 / 2$ MIC to $1 / 32$ MIC) of the antibiotic agent tested an overnight culture of bacteria was washed with PBS and diluted into fresh broth to a concentration of $10^{5}$ $\mathrm{cfu} / \mathrm{ml}$. After 2 hours of gentle shaking the antibiotic agent was added and incubated another two hours at $37^{\circ} \mathrm{C}$. Then the bacteria were washed again and a suspension containing $10^{7}$ bacteria/ml in fresh broth was used in the adherence assay. For the ELISA and DNA probe assay an overnight culture 
without shaking was used, grown in the presence of the appropriate subinhibitory concentration of norfloxacin or trimethoprim if necessary.

\section{ADHERENCE ASSAY.}

The method of Daifuku and $\mathrm{Stamm}^{3}$ was performed with slight modifications using the T24 human urinary bladder carcinoma cell line (ATCC HTB-4). In short, nonconfluent monolayers of T24 cells (approximately $10^{4}$ cells) in 6 wells dishes (Costar) were obtained by culturing in MEM (GIBCO) containing 10\% fetal bovine serum (GIBCO) in an atmosphere of $5 \% \mathrm{CO}_{2}$ overnight. A suspension containing Escherichia coli (diluted from an overnight culture to $10^{7} \mathrm{cfu} / \mathrm{ml}$ ) was added to the T24 cells. After $1 \mathrm{hr}$ incubation at $37^{\circ} \mathrm{C}$ under gentle shaking the suspension was removed and the cells were rigourously washed at least 5 times with $0.9 \%$ $\mathrm{NaCl}$ solution, dried, fixed with ice-cold methanol and stained with Giemsa $30 \%(\mathrm{~N} / \mathrm{v})$. The number of bacteria adhered to 25 cells in 1 well were counted by light microscopy. Each experiment was performed in triplicate. So for each bacteria/antibiotic combination 75 cells were counted and the adherence was expressed as the median number of bacteria adhered per cell.

Morphology after $4 \mathrm{hr}$ or overnight incubation of treated and nontreated bacteria was assessed by light microscopy.

To control for the number of bacteria used in the assays the Miles and Misra method ${ }^{15}$ was used both from a $4 \mathrm{hr}$ and an overnight culture in the presence and absence of the antimicrobial agent.

MONOCLONAL ANTIBODIES.

Monoclonal antibodies (MAbs) against $F 7_{1}, F 7_{2}, F 8, F 9, F 11$ and $F 12$ fimbriae were produced and described by de Ree et al. ${ }^{16}$.

WHOLE BACTERIA ELISA.

An ELISA with whole bacteria as antigen was carried out as described by de Ree et al. ${ }^{16}$. Briefly, bacteria were coated to microtiter plates and preincubated with $1 \% \mathrm{w} / \mathrm{v}$ BSA followed by incubation of MAbs. Antifimbriae activity was detected colorimetrically after incubation with goat-anti-mouse antiserum, conjugated with peroxidase and addition of the substrate o-phenylenediamine. Absorbance at $495 \mathrm{~nm}$ was determined with a Titertek multiscan ELISA plate reader. Cross reactions of the MAbs against other fimbriae were checked as described by de Ree ${ }^{16}$. Strain HB101 was used as a negative control strain. Results of the ELISA assay were given as the optical density (OD) minus the control value of MAbs incubated without bacteria.

PURIFICATION OF P FIMBRIAE PROBE AND RNA ISOLATION.

Plasmid DNA was isolated by the method of Maniatis ${ }^{19}$. The $\mathrm{P}$ fimbrial probe consisted of a $7.3 \mathrm{~kb}$ Clal fragment of AM1727 pPil 288-10 ${ }^{16}$ encoding part of the fimbrial genes. (The strain was kindly provided by J.de Ree). The 
physical map of the gene cluster encoding F9 fimbriae of pPil 288-10 is shown in Figure I. The subunit encoding the adhesin, called minor fimbrillins, are included. The major pilin subunit is not required for binding and was excluded from the probe fragment used in this assay. The probe was labeled with digoxigenin according to the manufacturer's instructions (Boeringer Mannheim, Mannheim, Germany).

Figure I RESTRICTION MAP OF $p$ PIL 288-10 (24 KB). THE SOLID BLACK BAR REPRESENTS THE WECTOR PJB8, THE STRIPED BAR THE PART ENCODING THE MAIOR FIMBRILLIN, THE DOTTED BAR THE REST OF THE GENE CLUSTER ENCODING THE FIMBRLAE AND THE PART OF PPIL 288-10 THAT WAS USED AS A PROBE IN THIS ASSAY. THE BLANK BAR REPRESENTS THE PARTS OF PPIL 288-10 NOT USED.

ClaI

ClaI

ClaI

ClaI

Sall

Bglil Kpnl

BginI KpnI BgllI

RNA was isolated by the guanidine-thyocyanate method ${ }^{19}$. In short, bacteria were lyzed with lysozyme $(2.5 \mathrm{mg} / \mathrm{ml})$ and the RNA was extracted with a solution containing guanidine-thyocyanate $(4 \mathrm{M})$, sodium citrate $(20 \mathrm{mM}), \mathbb{B}$-mercaptoethanol $(0.5 \%)$ and sarcosyl $(0.5 \%)$, purified with phenol-chloroform $(49: 1)$ extractions and with pure ethanol. RNA was then transferred to nylon membranes (Nytran. Schleicher \& Schuell, Den Bosch, The Netherlands). Purity of RNA was checked by gelelectrophoresis and OD 280:260 ratios.

Prehybridization and hybridization were done under stringent conditions at $42{ }^{\circ} \mathrm{C}$ in formamide $50 \%, 5 * \mathrm{SSC}$, sarcosyl $0.1 \%$, SDS $0.02 \%$, salmon sperm $0.5 \%$ and blocking reagent (Dig kit, Boehringer Mannheim, Mannheim, Germany) with washes in $2 * \mathrm{SSC}$ and $0.1 \%$ SDS at $68^{\circ} \mathrm{C}$. Detection of digoxigenin labeled nucleic acids was performed by chemoluminescence on radiographic films (Kodak X Omat AR).

AM1727 pPil288-10 (16) and HB101 were used as the positive and negative controls respectively. The amount of RNA was assessed semiquantitatively.

\section{ELECTRON MICROSCOPY}

Escherichia coli P 577 was streaked on CFA agar plates with and without norfloxacin (1/2 to $1 / 32 \mathrm{MIC})$ and trimethoprim (1/4 and 1/8 MIC). After overnight incubation colonies were suspended in Ammoniumacetate (0.1 M, PH 6.8) and one drop of this suspension was placed on carbon-plated

Op pagina 79 is de restriction map van pPIL288-10 weggevallen. 
copper grids and allowed to stand for a few minutes at room temperature; the excess suspension was drained off, and the adherent bacteria were negatively stained with methylamine tungstate (Biorad) for 5 seconds. Grids were examined by electron microscopy (EM) (Philips CM10) at $80 \mathrm{kV}$.

STATISTICS.

Difference between proportions were tested with the chi-square test for independent proportions, using a two-sided confidence level of $5 \%$.

For the adherence assay the median instead of the mean was used because of a non-Normal distribution ${ }^{18}$. The nonparametric Mann-Whitney-U test ${ }^{22}$ was applied to the results of the adherence assay.

\section{RESULTS}

The MIC of the Escherichia coli strains used ranged from 0.063 to $0.125 \mu \mathrm{g} / \mathrm{ml}$ for norfloxacin, for ofloxacin the MIC was for all but 1 strain (P139) $0.063 \mu \mathrm{g} / \mathrm{ml}$, for ciprofloxacin the MIC ranged from 0.004 to 0.016 $\mu \mathrm{g} / \mathrm{ml}$, and for trimethoprim the MIC ranged from $0.25 \mu \mathrm{g} / \mathrm{ml}$ to $64 \mu \mathrm{g} / \mathrm{ml}$.

After incubation with different concentrations of the 3 quinolones during 2 and 24 hours rather no morphological changes were visible by light microscopy. Only incubation with $1 / 2$ MIC norfloxacin during 2 and 24 hours revealed bacterial elongation in all 6 strains.

Viable counts revealed no differences between antibiotic exposed strains as compared with the control one. ANTIBODIES AGAINST P FIMBRIATED BACTERIA. MONOCLONAL ANTIBODIES USED ARE LISTED IN TABLE I.
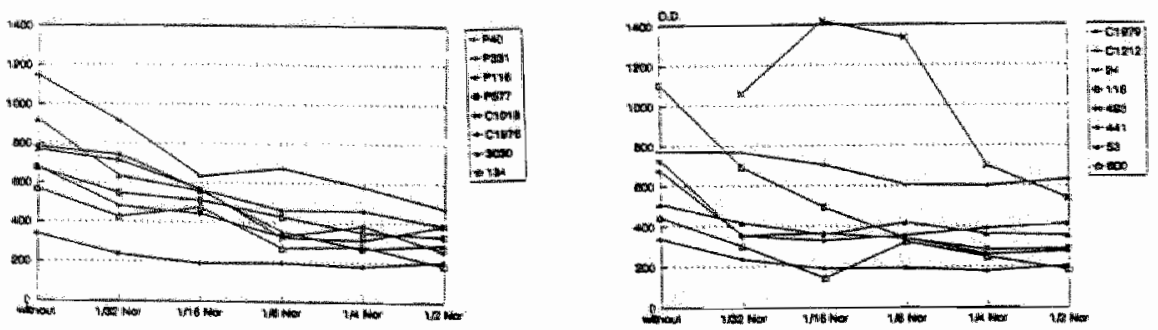
Figure II INFLUENCE OF SUBMICS OF TRIMETHOPRIM IN AN ELIISA USING MONOCLONAL AMTIBODIES AGANST P FIMBRIATED BACTERIA. MONOCLONAL ANTIBODIES USED ARE LISTED IN TABLE I.
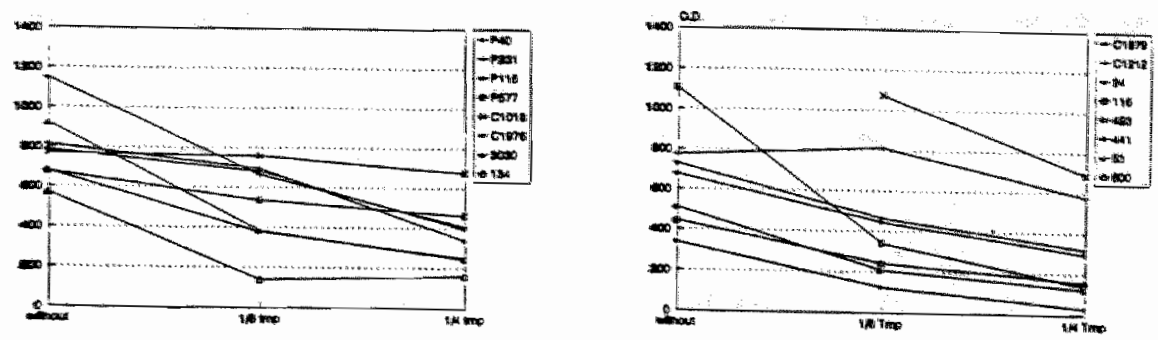

The results of the whole bacteria ELISA of the strains exposed to norfloxacin and trimethoprim are presented in figures II and III respectively. Concentrations from $1 / 32$ to $1 / 2$ MIC of norfloxacin and trimethoprim resulted in almost all strains in a decrease in $\mathrm{OD}_{495}$. If an effect was observed with trimethoprim a similar decrease was observed with norfloxacin. In most cases the amount of $\mathbf{P}$ fimbrial RNA decreased correspondingly (Table II). The effect was most pronounced with $1 / 4 \mathrm{MIC}$ and 1/8 MIC of norfloxacin and 1/4 MIC of trimethoprim.

No differences in total amount of fimbriae of strain P577 was observed using electron microscopy in the presence of $(1 / 2$ to $1 / 32 \mathrm{MIC})$ of trimethoprim or norfloxacin compared to the control without antibiotic.

All 6 Escherichia coli strains tested in the adherence assay adhered quite well to T24 uroepithelial cells (Table II). Differences between the strains, with respect to the median number of bacteria adhering to the T24 uroma cells, did occur. The median number of bacteria ranged from 36 to 191 bacteria per uroepithelial cell for CYS strains and from 22 to 45 bacteria per cell for $\mathrm{ABU}$ isolates.

In all strains, except one $A B U$ strain, adherence decreased significantly in the presence of $1 / 2$ MIC of norfloxacin. Ciprofloxacin gave a significant decrease in only one P fimbriated strain. The presence of ofloxacin resulted 
in one CYS strain in a decrease of adherence, an increase in adherence was observed in two ABU isolates (Table III).

Table I INFLUENCE OF TRIMETHOPRIM AND NORFLOXACIN ON THE RELATTVE AMOUNT OF RNA OETECTED WITH A SPECIFIC P FIMBRIAL DNA PROBE.

\begin{tabular}{|c|c|c|c|c|c|c|}
\hline \multirow[b]{2}{*}{$M I C(\mu \mathrm{g} / \mathrm{ml})$} & \multicolumn{6}{|c|}{ STRAINS } \\
\hline & 40 & 89 & 116 & 331 & 577 & 714 \\
\hline & \multicolumn{6}{|c|}{ SEROTYPE } \\
\hline & F11 & - & $\mathrm{F} 8$ & Fil & $F 7^{\prime}$ & - \\
\hline 0 & +4 & $+t$ & ++ & ++ & ++ & $+t$ \\
\hline U/32 norfloxacin & ++ & + & +4 & + & + & + \\
\hline 1/16 norfloxacin & - & +1 & $+1-$ & $+1-$ & - & $+1-$ \\
\hline 1/8 norfloxacin & - & +1 & - & - & - & - \\
\hline $1 / 4$ norfloxacin & - & . & - & - & - & - \\
\hline $1 / 2$ norfloxacin & +1 & + & . & ++ & $+1=$ & +1 \\
\hline \multirow[t]{3}{*}{ 1/4 trimethoprim } & +1 & +1 & $+1-$ & +1 & + & + \\
\hline & \multicolumn{6}{|c|}{ CONTROL STRAINS } \\
\hline & $\mathrm{HBJO1}$ & C1018 & & & & \\
\hline 0 & - & $4+4$ & & & & \\
\hline 1/4 trimethoprim & & + & & & & \\
\hline
\end{tabular}

Table III THE MEDIAN OF THE NUMBER OF BACTERIA ADHERED TO 75 UROMA T24 CELLS. IN THE ABSENCE AND IN THE PRESENCE OF THE INVESTIGATED QUINOLONES.

STRAINS WTTHOUT 1/2 MIC NORFLOXACIN 1/2 MIC CIPROFLOXACN I/2 MIC OFLOXACIN

$\begin{array}{llllll}1281 & \text { P577 } & 57 & 6 ! & 42 & 46 \\ 139 & \text { P331 } & 36 & 2^{1} & 35 & 34 \\ 889 & \text { P714 } & 191 & 62^{1} & 60 & 129^{1} \\ 590 & \text { P89 } & 22 & 16^{1} & 19 & 35^{2} \\ 4620 & \text { P116 } & 45 & 26^{11} & 38 & 33 \\ 4313 & \text { P40 } & 35 & 25 & 22 & 82^{2}\end{array}$

${ }^{1} p<0.05$ DEcreased adherence in the presence of $1 / 2$ MIC of the investigated quinollone.

${ }^{2} \mathrm{p}<0.05$ INcreased adherence in the presence of $1 / 2 \mathrm{MHC}$ of afloxacin 


\section{DISCUSSION}

In the present study a decrease in adherence of CYS and ABU Escherichia coli strains to uroepithelial cells was observed in the presence of norfloxacin.

An important issue is the way the results were analyzed. Rosenstein ${ }^{18}$ reported in a meta-analysis of adherence assays and observed that bacteria adhered to epithelial cells in a non-normal way. It meant that bacteria adhered to some epithelial cells with large numbers, while other epithelial cells had only small numbers of adhering bacteria. Therefore in the analysis of the results a non-parametric analysis applied to medians has to be used. Also in the present study the adherence of the strains showed a non-normal distribution, so the results were analyzed applying the Mann-Whitney-U-test ${ }^{22}$ because a parametric test was not the correct choice ${ }^{18 .}$

With respect to the results of the ELISA an obvious decrease of the OD in the presence of subMICs of quinolones was observed. The monoclonal antibodies used in this assay are directed against the adhesin protein of the fimbriae. The probe used for the detection of the P fimbrial RNA is directed against all genes involving fimbrial production except the gene encoding for the major fimbrillin part. In both assays a concentration dependent influence of subMICs of norfloxacin was observed. Both assays can detect the influence on the adhesin part, therefore the results of the present study suggest an influence of norfloxacin on the adhesin of the fimbriae, in stead of an influence on the presence of the fimbriae. Absence of fimbriae in the presence of subMICs are not confirmed with our data of EM, because EM did not show any difference between the amount of fimbriae of bacteria cultured in the presence and absence of subMICs of antimicrobial agents. However if the adhesin itself was influenced, as suggested by the results of the ELISA and RNA assay, this could not have been detected with EM. Further analysis to the possible mechanism of its decreased adherence in the presence of subMICs of trimethoprim or norfloxacin suggests furthermore a strain dependent effect. The effect of the subMICs was not in all strains equal. A possibility is that the serotype might influence the effect, although from the strains tested no such effects were observed.

With respect to the results of the other quinolones in the adherence assay as assessed with light microscopy rather no influence with ofloxacin and ciprofloxacin was observed. Although the 3 quinolones are structurally and chemically related, there are differences lypophilicity and in antibacterial 
activity. It might be possible that these differences play a role in the differences in effect observed in the adherence assay.

In conclusion the results of this study indicate that subMICs of norfloxacin decreases the adhesion of Escherichia coli strains to uroepithelial cells. The data of the ELISA and RNA assay and the electron microscopic studies suggest that this influence is directed against the adhesive part itself of the $P$ fimbriae. However a strain dependent influence was observed.

We would like to thank R. Hendrix, M.D., for his help with technical, P.Terporten, B.Sc., for his help with statistical problems. We also like to thank the department of electron microscopy, in particular P.Bomans, B.Sc., for his assistance in the preparation of the electron microscopic studies. 


\section{REFERENCES}

1 Beachey E.H. 1981. Bacterial adherence: adhesin receptor interactions mediating the attachment of bacteria to mucosal surface. J. of Infect. Dis. 143:325-345.

2 Chopra I., A.Linton. 1986. The antibacterial effects of low concentrations of antibiotics. Adv. Microbiol. Physiology. 28:211-259.

3 Daifuku R. and W.E.Stamm. 1986. Bacterial adherence to bladder uroepithelial cells in catheter associated urinary tract infections. New Engl. J. Med. 314: 1208-1213.

4 Dean E.A. and R.E.Kessler. 1988. Quantitation of effects of subinhibitory concentrations of trimethoprim on $\mathrm{P}$ fimbria expression and in vitro adhesiveness of uropathogenic Escherichia coli. J.Clin.Microbiol. 26:25-30.

5 Desnottes J.F., N.Diallo, C.Loubeyre, N.Moreau. Effect of pefloxacin on microorganism: host cell interaction. J.Antimicrob.Cemother. 26 Suppl. B: 17-26.

6 Duguid J.P., C.Clegg, M.I.Wilson. 1979. The fimbrial and nonfimbrial haemagglutinins of Escherichia coli J.Med.Microbiol. 12:213227.

7 Hooper D.C., J.S.Wolfson, E.Y.Ng, M.N.Swartz. Mechanism of action and resistance to ciprofloxacin. Am J of Med 1987; 82 suppl 4A: $12-20$.

8. O'Hanley P., D.Low, I.Romero, D.Lark, K.Vosti, S.Falkow, G.Schoolnik. 1985. Gal-Gal binding and hemolysin phenotypes and genotypes associated with uropathogenic Escherichia coli. New Engl. Med. 313:414-420.

9 Jacobson S.H., M.Katouli, K.Tullus, A.Brauner. 1990. Phenotypic differences and characteristics of pyelonephritogenic strains of Escherichia coli isolated from children. J. Infection. 21:279-286.

10 Johnson J.R.. 1991. Virulence factors in Escherichia coli urinary tract infection. Clin. Microbiol. Rev. 4:80-128.

11 Källenius G., S.B.Svenson, H.Hultberg, R.Möllby, I.Helin, B.Cedergren, J.Winberg. 1981. Occurrence of P-fimbriated Escherichia coli in urinary tract infections. Lancet. 1369-1372.

12 Korhonen T.K., R.Virkola, B.Westerlund, H.Holthöfer; J.Parkkinen. 1990. Tissue tropism of Escherichia coli adhesins in human extraintestinal infections. Curr. Topics in Microbiol. Immun. 151:115126. 
13 Kovarik J.M., I.M.Hoepelman, J.Verhoef. 1989. Influence of fluoroquinolones on expression and function of $\mathrm{P}$ fimbriae in uropathogenic Escherichia coli. Antimicrob. Agents Chemother. 133:684-688.

14 Krogfelt K.A. 1991. Bacterial adhesion: genetics, biogenesis and role in pathogenesis of fimbrial adhesins of Escherichia coli. Rev. of Infect. Dis, 13:721-735.

15 Miles A.A. and S.S.Misra. 1938. J. Hyg. 38:732.

16 de Ree J.M., P.Schwilllens, J.F vd Bosch. 1985. Molecular cloning of F11 fimbriae from an uropathogenic Escherichia coli and characterization of fimbriae with polyclonal and monoclonal antibodies. FEMS Microbiol. Lett. 29:91-97.

17 Reîd G. and J.D.Sobel. 1987. Bacterial adherence in the pathogenesis of urinary tract infection: a review. Rev. of Infect. Dis. 9:470487.

18 Rosenstein I.J., D.Grady, J.M.T. Hamilton-Miller, W.Brumfitt. 1985. Relationship between adhesion of Escherichia coli to uroepithelial cells and the pathogenesis of urinary tract infection: problems in methodology and analysis. J Med. Microbiol. 20:335-344.

19 Sambrook J., E.F.Fritsch, and T.Maniatis. 1989. Molecular cloning: a laboratory manual. 2nd ed. Cold Spring Harbor Laboratory, Cold Spring Harbor; N.Y.

20 Sandberg T., K.Stenqvist, C.Svanborg-Eden. 1979. Effects of subminimal inhibitory concentrations of ampicillin, chloramfenicol and nitrofurantoin on the attachment of Escherichia coli to human uroepithelial cells in vitro. Rev of Infect.Dis. 1:838-844.

21 Schifferli D.M., S.N.Abraham, E.H.Beachey. 1986. Influence of trimethoprim and sulfamethoxazole on the synthesis, expression and function of type I fimbriae of Escherichia coli. J of Infect: Dis. 154: 490-496.

22 Schreuder F. Handboek gegevens analyse met SPSS/PC +. Academic Service 1991. Schoonhoven.

23 Stenqvist K., T.Sandberg, S.Ahlstedt, T.K.Korhonen, S.SvanborgEden. 1982. Effect of subinhibitory concentrations of antibiotics and antibodies on the adherence of Escherichia coli to human uroepithelial cells in vitro. Scand. J. Infect. Dis. suppl.33:104-107.

24 Stenqvist K., T.Sandberg, G.Lidin-Janson, F.Orskov, I.Orskov, C.Svanborg. 1987. Virulence factors of Escherichia coli in urinary isolates from pregnant women. J Infect Dis. 156:870-877.

25 Svanborg-Eden C., U.Jodal, L.Å.Hanson, U.Lindberg, A.Sohl, J. Åkerlund. 1976. Variable adherence to human urinary tract epithelial 
cells of Escherichia coli strains associated with various forms of urinary tract infections. The Lancet. 490-492.

26 Väisänen V., L.G.Tallgren, P.H.Mäkelä, et al. 1981. Mannoseresistant haemagglutination and $\mathrm{P}$ antigen recognition are characteristics of Escherichia coli causing primary pyelonephritis. Lancet; 1366-1369.

27 Väisänen V., K.Louhatmaa, T.K.Korhonen. 1982. Effect of sublethal concentrations of antimicrobial agent on the hemagglutination, adherence and ultrastructure of pyelonephritogenic Escherichia coli strain. Antimicr.Agent Chemother. 22: 120-127.

28 Vosbeck K., H.Mett, U.Huber, J.Bohn, M.Petignat. 1982. Effects of low concentrations of antibiotics on Escherichia coli adhesion. Antimicrob. Agents Chemother.21:864-869.

29 Wolfson J.S., D.C.Hooper. Norfloxacin: a new targeted fluoroquinolone antimicrobial agent. Ann Int Med 1988; 108: 238-251.

30 Zhanel G.G., L.E.Nicolle. 1992. Effects of subinhibitory antimicrobial concentrations (subMICs) on in vitro bacterial adherence to uroepithelial cells. J. Antimicrob. Chemother. 29:617-627. 
88 
CHAPTER VII

GENERAL DISCUSSION 
90 


\section{INTRODUCTION}

This thesis describes factors influencing the efficacy of antimicrobial agents in urinary tract infections (UTD): the bacterial susceptibility, the optimal treatment duration and the effect of subinhibitory concentrations of antimicrobial agents on bacterial virulence factors.

\section{BACTERIAL RESISTANCE}

The results of the antibiotic susceptibility testing of 1200 uropathogens isolated in the south of the Netherlands in the period from 1989 until the beginning of 1991 showed that the susceptibility rates of Escherichia coli isolates to sulfamethoxazole and amoxycillin were $78 \%$ and $60 \%$ respectively, and to trimethoprim, co-trimoxazole, nitrofurantoine and norfloxacin $88 \%, 88 \%, 93 \%$ and $100 \%$ respectively. These data illustrate the general trend that the longer an antimicrobial agent has been used the lower the susceptibility rates of the bacteria are. One example is norfloxacin, which has been introduced recently. Although a decrease in susceptibility rates of Escherichia coli to $95.6 \%$ has occurred in the period from 1988 to 1991 in Spain ${ }^{1}$, where norfloxacin has been used more extensively than in the Netherlands, the susceptibility rates in the present study are still about $100 \%$. Sulfamethoxazole and amoxycillin have both been prescribed for a longer period and consequently the susceptibility of Escherichia coli to those agents has substantially declined. The still high percentage of bacteria susceptible to nitrofurantoin is an exception to this rule $^{2}$. This might be explained by pharmacokinetic properties: two third is rapidly metabolized, the other one third is excreted unchanged into the urine, and as a consequence the bowel flora is not exposed ${ }^{3}$. Since the general concept is that only in the bowel the sufficient numbers of bacteria are present that are required for the development of resistance, resistance might hardly develop ${ }^{4}$.

It is obvious that the results of antibiotic susceptibility surveys are relevant to general practitioners. Of importance are the observed differences between regions. A study from the National Institute of Public Health (RIVM), performed in the middle of the Netherlands in 1989, showed antibiotic susceptibility rates for amoxycillin, sulphamethoxazole, trimethoprim, co-trimoxazole and nitrofurantoin of $66 \%, 55 \%, 76 \%, 76 \%$ and $97 \%$ respectively ${ }^{5}$. These percentages differ from the present results, in that the susceptibilities of Escherichia coli isolates from UTI are lower than the susceptibilities to sulphamethoxazole, trimethoprim and co-trimoxazole found in the present study. However, a comparison with the study by Stobbe- 
ringh $^{6}$, a study performed in the south of the Netherlands from 1987 to 1988 , shows an overall similar pattern of the susceptibilities as observed in the present study. This indicates a certain stability of susceptibilities within one region, although minor differences in susceptibilities do occur. Gruneberg observed in his studies on resistance development important trends over a period of 20 years. However between two consecutive years only minor differences were observed, suggesting that changes develop over a period of years. The present study and the studies mentioned above illustrates that to provide the general practitioner with relevant data on susceptibility patterns, prospective methodological studies should be performed. The surveillance should include representative collections of strains, performed regularly and, because regional differences do occur, set up on a regional basis. In addition it is important to study in depth the types and clonality of bacteria and the mechanisms of resistance by application of molecular biological techniques. The data from these studies, especially when related to the use of antimicrobial agents, might provide means for early detection of resistance development ${ }^{8-14}$.

On the basis of the susceptibilities of the uropathogens as shown in the present study, amoxycillin and sulphamethoxazole can not be recommended as first choice agents. Instead trimethoprim, co-trimoxazole and nitrofurantoin should be preferred, despite the fact that more adverse effects might be expected with the use of nitrofurantoin and co-trimoxazole. With respect to the use of trimethoprim, however, the reports in the literature strongly indicate that the sulpha-component accounts for the majority of adverse effects; whereas it adds little to the antibacterial activity ${ }^{15}$. It might therefore be preferable to prescribe trimethoprim instead of co-trimoxazole for UTI. In the present situation norfloxacin should not be used, but reserved for treatment failures or in case of documented resistance. With this approach resistance development against norfloxacin might be delayed.

\section{THREE DAYS' TREATMENT}

As discussed in chapter I valid conclusions could not be drawn from the majority of studies on therapeutic efficacy because they did not fulfill the recommendations on clinical evaluation of antimicrobial agents in randomized controlled trials as made by the Working Party of the British Society of Antimicrobial Chemotherapy and Philbrick et al. ${ }^{16,17}$. The most frequent requirement not fullfilled was the inclusion of a sufficient number of patients: if the number of patients was too small a true difference could not be detected $^{18}$. 
Statistical calculations indicated that 280 patients were sufficient to reach the required power in our study ${ }^{18}$. The number of patients included in the present study was based on the intention to treat method. The patients were included in the trial by the general practitioner on the basis of clinical signs of UTI and received medication and all patients had to be evaluated at the end of the trial. It was anticipated that a number of included patients would be lost during the follow-up period. Therefore the number of patients included was higher than the 280 that were required as shown by the calculations. The number of patients finally included in the two studies was 327 and 384 respectively, and 280 and 290 patients were finally left for evaluation.

Another question to discuss is that not in all patients infection could be verified by a positive urine culture and it might therefore be expected that these patients did not have an UTI. Moreover at least two considerations demand that they remain included in the study group. First, from a statistical point of view all manipulations of the treatment groups after randomization have the danger to invalidate the data ${ }^{22}$. Second, the inclusion criteria of the patients are complaints of an acute UTI and in this respect the evaluation was done. For studies in general practice it might be emphasised, that this is the only relevant approach. Moreover, routine urine cultures may be false negative and therefore a clearly symptomatic patient is a candidate for treatment even in case of a negative culture.

Fihn et al. ${ }^{20}$ compared a single dose versus a 10 days' course of cotrimoxazole, in a trial with a sufficient number of patients and concluded that a single dose co-trimoxazole was less effective than a 10 days' course, and suggested that a trial with a three days" course should be conducted. Also Norrby ${ }^{21}$ concluded, that single-dose treatment was less effective than a seven to ten days' course of antimicrobial therapy for the treatment of acute uncomplicated urinary tract infections. His recommendations included that a three days' course of co-trimoxazole and the fluoroquinolones should be studied. Therefore the present studies tested co-trimoxazole as well as norfloxacin, comparing a three versus a seven days" course. The results obtained in both studies indicate that a three days' course of antimicrobial treatment is as effective as a seven days' course in the treatment of uncomplicated urinary tract infection in non-pregnant female patients in general practice. Based on the literature and on our results a three days course of antimicrobial agents can therefore be recommended in uncomplicated UTI, although extrapolations to other than the investigated antimicrobial agents should be made carefully ${ }^{21-23}$. 
A three days' course with co-trimoxazole, trimethoprim and nitrofurantoin as first choice agents, is also recommended by the Dutch General Practitioners Association (NHG) ${ }^{24}$. However the National Organization for Quality Insurance in Hospital (CBO) and the Drug Bulletin (Geneesmiddelenbulletin $^{25,26}$ favor a single dose treatment whereas in the latter especially amoxycillin and fosfomycin trometamol are recommended. For amoxycillin, reviewed by Philbrick ${ }^{17}$, sufficient data are available to support this approach. However, resistance percentages to this antimicrobial agent in the present study of $30-40 \%$ in uropathogens derived from uncomplicated urinary tract infections in general practice, indicate that this approach is not applicable in all situations. Fosfomycin trometamol might be an adequate medication as a single dose agent, but data from a randomized controlled trial with a sufficient number of patients in general practice to prove its efficacy, are not yet available.

A shorter treatment course reduces costs, the exposure time to the antimicrobial agent and the number of adverse effects and warrant a better patient compliance ${ }^{27}$. A considerable advantage is also the shorter exposure time of the bacteria in the bowel flora to the antimicrobial agents, reducing the likelihood on resistance development.

In conclusion the two present studies indicate and further substantiate the more and more accepted approach, as mentioned before, that a three days' course of antimicrobial treatment is probably an optimal treatment for acute UTI in general practice.

\section{SUBINHIBITORY CONCENTRATIONS}

It has been observed that in general subinhibitory concentrations of antimicrobial agents do effect bacteria, among others their virulence factors. In UTI it has been shown that important virulence factors are adherence, $\mathrm{P}$ fimbriae, hemolysin and aerobactin production.

Inhibition or suppresion of hemolysin and aerobactin production due to the subinhibitory concentrations of antimicrobial agents tested could not be demonstrated in this study.

The published results indicate that trimethoprim influences the adherence and the production and expression of $P$ fimbriae ${ }^{29,30}$. Since little information was available on the effect of subinhibitory concentrations of fluoroquinolones on adherence, three of the newer quinolones, norfloxacin, ofloxacin and ciprofloxacin were studied in comparison with trimethoprim.

With respect to the effect of these quinolones on adhesion the results indicated that norfloxacin diminished the adherence of Escherichia coli. A 
similar inhibitory effect of ciprofloxacin and ofloxacin could however not be demonstrated, however the number of strains investigated was limited and data in literature indicate that strains do vary in their susceptibility to subinhibitory effects. Apparently the similarity in structure and mechanism of action of the three quinolones does not exclude differences in antimicrobial effects ${ }^{30}$.

Further analysis of the influence of norfloxacin on adherence by means of a $\mathrm{P}$ fimbrial probe indicated that the amount of $\mathrm{P}$ fimbrial RNA isolated from bacteria treated with subinhibitory concentrations of norfloxacin was reduced. Using monoclonal antibodies against $P$ fimbriae in an ELISA also indicated that $P$ fimbrial adhesion was diminished as a result of subinhibitory concentrations of norfloxacin. Electron microscopic studies showed that the density and the number of fimbriae in comparison to untreated bacteria was not reduced ${ }^{31}$.

The clinical significance of the use of subinhibitory concentrations of antimicrobial agents is the prevention and prophylaxis of UTI. In this respect a number of studies are of interest. In a study by Ben Redjeb ${ }^{32}$, patients with acute uncomplicated UTI were treated with subinhibitory concentrations of amoxycillin and a cure rate of $80 \%$ was observed. The value of this observation is, however, limited because of the relatively small number of patients. In addition, other studies on prophylaxis of UTI showed that UTI could be prevented with subinhibitory concentrations of several antimicrobial agents ${ }^{33-36}$. In the light of the present findings with norfloxacin it seems therefore of interest to explore further the efficacy of norfloxacin in low doses for the prevention and prophylaxis of UTI.

\section{GENERAL CONCLUSIONS AND RECOMMENDATIONS}

With respect to the factors influencing the efficacy of antimicrobial agents in urinary tract infections described in this thesis the following conclusions and recommendations can be made.

The most important recommendation concerns the choice of the antimicrobial agent made in the light of the antimicrobial susceptibilities of the uropathogens. A three days' treatment with trimethoprim or cotrimoxazole as first, nitrofurantoin as second and norfloxacin as third are the preferred choices. Sufficient data are available to support this, and it seems worthwhile to study a short-term course with nitrofurantoine. A singledose treatment with amoxycillin could also be supported, but care must be taken because of the high percentage of resistant uropathogens. 
With respect to the prevention of UTI sufficient data from the literature and the present study support the use of trimethoprim, co-trimoxazole, norfloxacin and to a lesser degree of amoxycillin in low doses for the prophylaxis of UTI. With respect to norfloxacin it should not be recommended as long as trimethoprim and nitrofurantoine are still effective for therapy.

As previously indicated it is strongly recommended to establish surveillance stations, which at regular intervals collect a sufficient and representative number of strains to study bacterial susceptibilities. Recommendations for initial therapy to general practitioners should be made on the basis of these susceptibility rates. In addition studies in depth with a limited number of selected strains should be performed to elucidate the epidemiology of the strains and the mechanisms of resistance. These data might provide a more anticipitory approach of the use of antimicrobial agents in UTI. 


\section{REFERENCES}

1 Aguiar J.M., J.Chacon, R.Canton, F.Baquero. The emergence of highly resistant fluoroquinolone-resistant Escherichia coli in community acquired urinary tract infections.

2 Preston C.A.K., A.W.Bruce, G.Reid. Antibiotic resistance of urinary pathogens isolated from patients attending the Toronto Hospital between 1986 and 1990. J Hosp Infect 1992; 22: 129-135.

3 Yao J.D.C., R.C.Moellering. Antibacterial agents. Chapter 108 in A.Balows (Ed) Manual of Clinical Microbiology Fifht edition 1991. American Society for Microbiology Washington D.C.

4 Möller J.K. Monitoring antimicrobial drug resistance in hospital microorganisms. Danish Med Bull 1990; 37: 263-274.

5 Neeling de A.J., J. de Jong, B.P.Overbeek, R.W. de Bruin, M.Dessens-Kroon, B van Klingeren. Kwantitatief gevoeligheids-onderzoek met intra- en extramurale isolaten van Escherichia coli. Rapport nr 359001002. National Institute of Public Health and Environmental Protection (RIVM).

6 Stobberingh E.E., A.W.Houben. Antibioticagebruik en antibioticaresistentie in de huisartspraktijk. NTvG 1990; 132: 1793-1797.

7 Gruneberg R.N. Changes in the antibiotic sensitivities of urinary pathogens, 1971-1989. J Antimicr Chemother 1989; 27: 933-937.

8 Fraser A. The use of antibiotics in general practice. Austr Fam Phys 1987; 16: 1264-1271.

9 Turnidge J. The rational prescribing of antimicrobials. Austr Fam Phys 1987; 16: 1259-1263.

10 Kunin C.M., K.S.Johansen, A.M.Worning, F.D.Daschner. Report of a symposium on the use and abuse of antibiotics worldwide. Rev Infect Dis 1990; 12: 12-19.

11 Vandepitte J., A.Manten. Het symposium 'Antibioticabeleid'. NTvG 1984 ; 128: $830-832$.

12 Murray B.E. New aspects of antimicrobial resistance and the resulting therapeutic dilemmas. J Infect Dis 1991; 163: 1185-1194.

13 O'Brien T.F. Global surveillance of antibiotic resistance. New Engl J Med 1992; 326: 339-340.

14 Davies J. Another look at antibiotic resistance. J Gen Microbiol 1992; 138: $1553-1559$.

15 Anonymous Co-trimoxazole, or just trimethoprim? Drug Ther Bull 1986; 24: no 5 . 
16 Working Party of the British Society of Antimicrobial Chemotherapy. The clinical evaluation of antibacterial drugs. I Antimicrob Chemother 1989; 23: suppl B.

17 Philbrick J.T., J.P.Bracikovski. Single-dose antibiotic treatment for uncomplicated urinary tract infections. Less for less? Arch Intern Med 1985; 145: 1672-1678.

18 Freiman J.A., T.C.Chalmers, H.Smith, R.R.Kuebler. The importance of beta, the type II error and sample size in the design and interpretation of the randomized controlled trial. New Engl $\mathbf{J}$ Med 1978; 299: 690-694.

19 Huitfeldt B. Statistical aspects of clinical trials of antibiotics in acute infections. Rev Infect Dis 1986; 8 suppl 3: 350-357.

20 Fihn S.D., W.E.Stamm. Interpretation and comparison of treatment studies for uncomplicated urinary tract infections in women. Rev Infect Dis $1985 ; 7: 468-478$.

21 Norrby S.R. Short-term treatment of uncomplicated lower urinary tract infections in women. Rev Infect Dis 1990; 12: 458-467.

22 Urinary Tract Infection Study Group. Coordinated multicenter study of norfloxacin versus trimethoprim-sulfamethoxazole treatment of symptomatic urinary tract infections. J Infect Dis; 155: 170-177.

23 The InterNordic Urinary Tract Infection Study Group. Doubleblind comparison of 3-day versus 7-day treatment with norfloxacin in symptomatic urinary tract infections. Scand J Infect Dis. 1988; 20: 619-624.

24 Balen v FAM, PJAM Baselier, E vPienbroek, RAG Winkens. Standaard Urineweginfecties Nederlands Huisartsen Genootschap. Huisarts en Wetenschap 1989; 32: 527-530.

25 Wetenschappelijke Raad Centraal Begeleidingsorgaan voor de Intercollegiale Toetsing (CBO). Het syndroom van de acute pijnlijke frequente mictie en de patient met een langdurige verblijfscatheter. juni 1988.

26 Mattie H., P.J.vd Broek. De behandeling van ongecompliceerde urineweginfecties: lang, kort of met een dosis behandelen. Geneesmiddelenbulletin 1991; 25: 46-48.

27 Cheung R. C.M.Sullens, D.Seal, J.Dickens, P.W.Nicholson, A.A. Deshmukh, M.J.Denham, S.M.Dobbs. The paradox of using a 7 day antibacterial course to treat urinary tract infections in the community. Br J Clin Pharmac. 1988; 26: 391-398.

28 Väisänen V., K.Lounatmaa, T.K.Korhonen. Effects of sublethal concentrations of antimicrobial agents on the hemagglutination, 
adhesion, and ultrastructure of pyelonephritogenic Escherichia colt strains. Antimicrob Agents Chemother 1982; 22: 622-625.

29 Kovarik J.M., I.M.Hoepelman, J.Verhoef. Influence of fluoroquinolones on expression and function of $\mathrm{P}$ fimbriae in uropathogenic Escherichia coli. Antimicr Agents Chemother 1989; 33: 684-688.

30 Furet Y.X., J.C.Pechere. Usual and unusual antibacterial effects of quinolones. J Antibact Chemother 1990; 26: suppl B 7-15.

31 Desnottes J.F., D.Le Roy, N. Diallo. Effect of subminimal inhibitory concentrations of pefloxacin on the piliation and adherence of Escherichia coli. Drugs Exptl Clin Res 1988; 14: 629-634.

32 Ben Redjeb S., A.Slim, A.Horchani, S Zmerrilli, A.Boujnah, V.Lorian. Effects of ten milligrams of ampicillin per day on urinary tract infections. Antimicrob Agents Chemother. 1982; 22: 1084-1086.

33 Wall v.d.E., R.P.Verkooyen, J.Mintjens-deGroot, J Oostinga, A v.Dijk, W.N.M. Hustinx, H.A.Verbrugh. Prophylactic ciprofloxacin for catheter associated urinary tract infection. The Lancet 1992; 339 : 946-951.

34 Brumfitt W., J.M.T.Hamilton-Miller. Prophylactic antibiotics for recurrent urinary tract infections. J Antimicr Chemother. 1990; 25: 505-512.

35 Nicolle L.E., G.K.M.Harding, M.Thompson, J.Kennedy, B.Urias, A.R.Ronald. Efficacy of five years of continuous, low-dose trimethoprim-sulfamethoxazole prophylaxis for urinary tract infections. J Infect Dis 1988; 157: 1239-1242.

36 Stamm W.E,, G.W.Counts, K.F.Wagner, D.Martin, D.Gregory, M.McKevitt, M.Turck, K.K.Holmes. Antimicrobial prophylaxis for recurrent urinary tract infections. A double blind, placebo-controlled trial. Ann Intern Med 1980; 92: 770-775. 
100 


\section{SUMMARY}

Urinary tract infections (UTI) are very common, especially in women. The infections are especially encountered in general practice, and remain a source of medical research. In this dissertation attention is paid to a number of factors that are important to the treatment of UTI with antibiotics. As a great deal has already been written on UTI, only the subjects relevant to this study are introduced in chapter I, namely the epidemiology of UTI, the defence mechanisms of the host, the virulence factors of Escherichia coli and the treatment of UTI.

In the majority of the cases the microorganism that causes UTI in individual patients in general practice is unknown. This means that the antimicrobial treatment is prescribed blindly, so without the general practitioner knowing the susceptibilities of the bacteria to antibioitcs. Therefore epidemiological knowledge of the anticipated microorganisms with their susceptibilities to antibioitcs is of the outmost importance to a succesful treatment and, as such, also to curing the patient.

In chapter II we describe the research into the susceptibilities of the bacteria isolated from urine samples of women who saw their general practitioner with acute UTI complaints in the Maastricht area. The most common causative agent of UTI in general practice is Escherichia coli $(80 \%)$. The susceptibilities to the antibiotic amoxycillin and sulphamethoxazole is so low, $60 \%$ and $78 \%$ respectively, that starting treatment blindly is too likely to fail. The susceptibilies of the bacteria to trimethoprim, co-trimoxazole, nitrofurantoine and norfloxacin is better, varying from 88 to $100 \%$.

Besides similar percentages, also differences in susceptibilities are found in literature. An important cause of the differences in the literature found is the decreasing susceptibility in time as a result of acquiring resistance in the bacteria investigated. Also there are differences between countries and even between areas in one country. Therefore it is advisable to monitor the prevalence of resistance to antibiotics at regular intervals with the help at surveillane stations in the various areas in a country. Besides, research should be done into the underlying mechanism of resistance with the help of molecular biological techniques.

With respect to the treatment-advice for general practice this means that on the basis of our susceptibilities trimethoprim, co-trimoxazole, nitrofurantoine and norfloxacin are a good choice to start with blindly. However, as a part of the prevention of resistance to antibioitcs it is advisable to restrict the use of norfloxacin to those cases where other antibioitcs fail. 
The length of the treatment also plays a role in the development of resistant bacteria. Bacteria acquire their resistance to antibioitcs through mutation. In the large intestine sufficient bacteria $\left(>10^{4}\right)$ are present for mutation to take place. The longer the treatment lasts, the longer concentrations of antibiotics are present in the large intestine and the greater a chance of a resistant mutant. So, if a shorter treatment can be given, this is also desirable with respect to the prevention of resistance.

In literature there is a lack of well-designed studies on short-term treatment for the various antibiotics carried out with a sufficient number of patients. In chapter III and VI the double-blind randomised study into the effectiveness of a three days' treatment is described, with the antibiotics cotrimoxazole and norfloxacin, research that was carried out with a sufficient number of patients. It appeared that a three days'course, with co-trimoxazole as well as with norfloxacin was as effective as as seven days" course to cure patients with acute uncomplicated UTI.

Not only the development of resistance, but also the compliance, sideeffects and costs are thus affected favourably.

Not only shortening of the treatment period but also the dosage of the antibiotic is worth investigating. Since the time treatment with antibioitcs was started it has been known that antibiotics in subinhibitory concentrations can affect bacterial growth without really killing them. It is possible that virulence factors of the bacteria, which are relevant to the adherence are affected by subinhibitory concentrations in such a way that the bacteria are not able to cause UTI any more.

In chapter $V$ and VI the research into th influence of subinhibitory concentrations of three quinolones, namely norfloxacin, ofloxacin and ciprofloxacin, on some virulence factors of Escherichia coli is described. The virulence factors studied are: the hemolytic activity, the adherence, P fimbriae and the production of aerobactin which all play an important role in the development of UTI.

The aerobactin production and the hemolytic activity were not affected by subinhibitory concentrations of these antibiotics. The quinolones did cause a decreased adherence of bacteria to uroepithelial cells. Also the adherence of $P$ fimbriae was reduced by norfloxacin. Electron microscopic pictures showed no reduction or absence of fimbriae, however. Probably norfloxacin affects the receptors at the ends of the $\mathrm{P}$ fimbriae without preventing all production of fimbriae.

So the most important step in the development of UTI, namely the adherence of bacteria to the epithelium, is decreased by the presence of subinhibitory concentrations of quinolones. Considering this, profylaxis of 
UTI by giving subinhibitory concentrations of quinolones could be envisaged. However further research is necessary here.

In the concluding chapter the results as presented in the chapters II to VI are examined and discussed and recommendations are made as mentioned in this summary. 


\section{SAMENVATTING}

Urineweginfecties (UWI) zijn een zeer vaak voorkomende kwaal, vooral bij vrouwen. Deze worden met name gezien in de huisartsenpraktijk, en blijven een bron van onderzoek voor de medische wereld. In dit proefschrift wordt aandacht besteed aan een aantal factoren die van belang zijn bij de behandeling van LWI met antibiotica. Omdat er al zeer veel geschreven is over UWI wordt in het eerste hoofdstuk alleen die onderwerpen ingeleid, die van belang zijn voor dit onderzoek, te weten, de epidemiologie van UWI, de verdedigingsmechanismen van de gastheer, de virulentiefactoren van Escherichia coli en de behandeling van UWI.

In de meerderheid van de gevallen is het microorganisme, dat de UWI bij individuële patienten in de huisartsenpraktijk veroorzaakt niet bekend. Dat betekent, dat de antimicrobiële therapie blind wordt voorgeschreven, dus zonder dat de huisarts de antibioticagevoeligheden van de bacterie weet. Epidemiologische kennis van de te verwachten microorganismen met hun antibiotica-gevoeligheden is dan ook van het grootste belang voor het slagen van de therapie en als zodanig ook voor de genezing van de patient.

In hoofdstuk 2 wordt het onderzoek beschreven dat werd verricht naar de gevoeligheden van de bacteriën, geïsoleerd uit urines van vrouwen die met klachten van acute UWI bij hun huisarts in de regio Maastricht kwamen. De meest voorkomende verwekker van UWI in de huisartsenpraktijk is de Escheríchia coli $(80 \%)$. De gevoeligheden van deze bacteriën voor de antibiotica amoxycilline en sulfamethoxazole is zodanig laag, $60 \%$ en $78 \%$ respectievelijk, dat blind starten met therapie een te grote kans op falen geeft. Voor trimethoprim, co-trimoxazole, nitrofurantoine en norfloxacin is de gevoeligheid van de bacteriën beter, varierend van $88 \%$ tot $100 \%$.

In de literatuur worden naast overeenkomstige, ook verschillen in percentages gevoeligheden gevonden. Een belangrijke oorzaak van de gevonden verschillen is de afnemende gevoeligheid in de tijd ten gevolge van het verwerven van resistentie in de onderzochte populatie. Ook is er verschil tussen landen en zelfs tussen regio's onderling. Daarom is het goed om de prevalentie van antibioticaresistentie met geregelde tussenpozen te monitoren met behulp van peilstations in de verschillende regio's binnen een land. Bovendien zou met behulp van moleculair biologische technieken onderzoek gedaan moeten worden naar de onderliggende mechanismen var resistentie.

Met betrekking tot het therapieadvies voor de algemene praktijk betekent dit dat trimethoprim, co-trimoxazole, nitrofurantoine en norfloxacin op basis van deze gegevens goede keuzes zijn om blind mee te starten. Echter in het kader van het voorkómen van antibioticaresistentie is het raadzaam het gebruik van norfloxacin te reserweren voor die gevallen waarin andere antibiotica falen. 
Ook de duur van de therapie speelt een rol bij het ontstaan van resistente bacteriën. Bacterièn verwerven hun resistentie tegen antibiotica via mutaties. In de dikke darm zijn voldoende bacteriën $\left(>10^{5}\right)$ aanwezig, om mutaties plaats te laten vinden. Des te langer de therapie duurt, des te langer antibioticaconcentraties in de dikke darm aanwezig zijn, en des te groter dus de kans op een resistente mutant. Als dus een kortere kuur gegeven kan worden, is dit dan ook wenselijk met betrekking tot het voorkómen van resistentie. De literatuur over kortere kuren vertoont echter nog een gebrek aan goed opgezette studies voor de verschillende antibiotica uitgevoerd met een voldoende aantal patiënten.

In hoofdstuk 3 en 4 wordt het dubbelblind gerandomiseerd onderzoek beschreven, met de antibiotica co-trimoxazole en norfloxacin, dat werd verricht met een voldoende aantal patiënten naar de effectiviteit van een driedaagse kuur. Hieruit bleek dat een driedaagse kuur, zowel met cotrimoxazole alsook met norfloxacin, even effectief was als een zevendaagse kuur om patiënten met een acute ongecompliceerde UWI te genezen.

Niet alleen de resistentieontwikkeling, maar ook de therapietrouw, bijwerkingen en de kosten worden zo in gunstige zin beïnvloed.

Net zoals verkorting van de therapieduur is ook de dosering van het antibioticum onderzoek waard. Al sinds de tijd dat antibiotica gebruikt worden is het bekend, dat antibiotica in subinhibitoire concentraties bacteriën in hun groei kunnen beïnvloeden, zonder dat ze daardoor werkelijk gedood worden. Het is mogelijk, dat virulentiefactoren van de bacteriën, die van belang zijn bij de aanhechting, door de subinhibitoire concentraties zodanig beïnvloed worden, dat de bacteriën niet meer in staat zijn om een UWI te verooorzaken.

In hoofdstuk 5 en 6 wordt dan ook het onderzoek beschreven naar de invloed van subinhibitoire concentraties van drie quinolonen, te weten norfloxacin, ofloxacin en ciprofloxacin, op enkele virulentiefactoren van Escherichia coli. De onderzochte virulentiefactoren zijn, de hemolytische activiteit, de aanhechting, P fimbriae en de aerobactine productie, welke allen een belangrijke rol spelen bij het ontstaan van UWI.

De aerobactine productie en de hemolytische activiteit werden niet beïnvloed door subinhibitoire concentraties van deze antibiotica. De quinolonen veroorzaakten echter wel een verminderde aanhechting van bacteriën aan uroepitheelcellen. Ook de P fimbriae werden in hun aanhechting verminderd door norfloxacin. Electronenmicroscopische opnames lieten echter geen vermindering of afwezigheid van fimbriae zien. Waarschijnlijk heeft norfloxacin dus een invloed op de receptoren, die aan het uiteinde van de $P$ fimbriae zitten, zonder de gehele fimbriaeproductie te verhinderen. 
De belangrijkste stap in het ontstaan van UWI, namelijk de aanhechting van bacteriën aan het epitheel, wordt dus verminderd door de aanwezigheid van subinhibitoire concentraties quinolonen. In dit kader zou de profylaxe van UWI door het geven van subinhibitoire concentraties quinolonen overwogen kunnen worden. Hiervoor moet echter nog nader onderzoek gedaan worden. Ter afsluitng worden in het laatste hoofdstuk de resultaten, zoals die beschreven zijn in de hoofdstukken 2 tot en met 6 , besproken en bediscussieerd en worden aanbevelingen gedaan zoals die ook in deze samenvatting vermeld staan. 


\section{DANKWOORD}

En toen was het af. Echter dit onderzoek is zeker niet alleen door mij tot stand gekomen. Vele mensen hebben aan dit onderzoek een bijdrage geleverd. Enkele hiervan wil ik met name noemen en hiervoor bedanken.

Als eerste natuurlijk alle patienten, die bereid waren aan het onderzoek mee te doen. Zonder hen was dit boekje nooit tot stand gekomen.

Alle huisartsen en hun assistentes, die toch steeds weer de tijd vonden om onze gele formulieren in te vullen. Al de uricults, urinepotjes, medicatie formulieren en urinestickjes, die ik bij hun heb afgeleverd. Hopelijk blijven ze aan het onderzoek en dus aan de drie-daagse therapie denken.

Marc, Germt, en de overige studenten, voor hun opbellen iedere dag naar de huisartsen en assistentes en het door weer en wind ophalen per fiets (en auto) van de uricults en urinepotjes. Record tot nu toe: 16 urines op een dag.

Ellen, mijn co-promotor, zonder jou zou dit onderzoek niet hebben plaatsgevonden. Jij was het, die de eerste opzet bedacht hebt, en mij in dit onderzoek betrokken hebt. Werkoverleg was iets wat in die eerste jaren in de werkkamer tussen de stapels tijdschriften in gebeurde, maar zeer effectief was. Later werden deze zaken meer gestructureerd. Heel snel was ook al duidelijk wat de kleur van dit boekje zou worden. Je ziet, dat je niet teleurgesteld wordt.

Professor van Boven en professor Knottnerus, mijn promotores, wil ik bedanken voor de begeleiding, vooral in de laatste fase van het onderzoek. Ik heb dit zeer gewaardeerd.

Anique, mijn eerste stagiaire, waarvan ik zeer veel practische zaken geleerd heb. Zij was het die een begin gemaakt heeft met de adherentie proeven, die zo veelbelovend waren en bleven.

Nancy, die eerst als stagiaire met plasjes, later zelf als AIO met poepjes werkzaam, altijd voor een goede sfeer op het lab zorgde, zeker bij het gezamelijk formulieren invoeren, en die met haar eerlijkheid soms onverwachte reacties opriep.

José, die altijd ergens vandaan de benodigde spullen, die vroeger gebruikt waren weer tevoorschijn kon toveren en daarbij mooie anekdotes kon vertellen.

Alle overige stagiaires, die in het kader van hun afstudeeropdrachten van het HLO bij ons op het lab hun onderzoek verrichtten.

Ton, voor zijn opzetten van het dbase programma waarin ik alle patientenformulieren kon invoeren, en voor zijn hulp jarenlang bij de gegevensanalyse via de vax en spss. 
Peter, die daarna de 'computer' beheerde en altijd wel tijd vond om uit te leggen hoe de statistiek nu moest gebeuren.

Ruth, Marjon, Jan en Christel voor de gezellige tijd toen we in het AZM werkzaam waren.

Ron Winkens, voor de samenwerking bij het project met de 'urinestickjes' in de huisartsenpraktijk; het blijft moeilijk een testje goed af te lezen.

Alle bacteriologische analisten, die er samen voor gezorgd hebben dat er een gezellige sfeer heerste, waarin het goed werken was.

Leny, Sjaak, Barbara en Tanny, voor hun geduld als ik weer eens bij de computer zat om iets te bewerken en uit te printen.

Rogeer, voor de hulp bij de Engelse teksten en vertalingen.

En last, but not least, Quir, die altijd geduld had als het mij weer eens allemaal teveel werd. Heb hoop, het boekje is nu eindelijk echt af. 


\section{CURRICULUM VITAE}

De schrijfster van dit proefschrift is op 9 januari 1961 in Tegelen geboren. In 1979 behaalde ze het Gymnasium- $\beta$ diploma aan het Collegium Marianum te Venlo.

$\mathrm{Na}$ haar eindexamen, uitgeloot voor geneeskunde, studeerde ze een jaar Pedagogiek aan de Rijks Universiteit Leiden, waarna ze overstapte naar de HBO-A analistenopleiding aan de Analistenschool te Venlo.

In 1981 werd ze ingeloot voor geneeskunde aan de Rijksuniversiteit Limburg in Maastricht. In 1988 werd het artsexamen behaald en kreeg ze een baan bij de vakgroep Medische Microbiologie in Maastricht. Eerst als parttime onderzoeker, vanaf april 1989 als assistent in opleiding, werkte ze aan het onderzoek, dat in dit proefschrift beschreven is.

Vanaf april 1993 is ze in opleiding tot medisch microbioloog bij professor C.P.A. van Boven in het Academisch Ziekenhuis Leiden. 